\title{
Historical antisemitism, ethnic specialization, and financial development
}

Article

Accepted Version

D'Acunto, F., Prokopczuk, M. and Weber, M. (2019) Historical antisemitism, ethnic specialization, and financial development. Review of Economic Studies, 86 (3). pp. 1170-1206. ISSN 1467-937X doi: https://doi.org/10.1093/restud/rdy021 Available at https://centaur.reading.ac.uk/75714/

It is advisable to refer to the publisher's version if you intend to cite from the work. See Guidance on citing.

To link to this article DOI: http://dx.doi.org/10.1093/restud/rdy021

Publisher: Oxford University Press

All outputs in CentAUR are protected by Intellectual Property Rights law, including copyright law. Copyright and IPR is retained by the creators or other copyright holders. Terms and conditions for use of this material are defined in the End User Agreement.

\section{www.reading.ac.uk/centaur}

\section{CentAUR}

Central Archive at the University of Reading

Reading's research outputs online 


\title{
Historical Antisemitism, Ethnic Specialization, and Financial Development
}

\author{
Francesco D'Acunto Marcel Prokopczuk Michael Weber *
}

This Version: February 2018

\begin{abstract}
Historically, European Jews have specialized in financial services while being the victims of antisemitism. We find that the present-day demand for finance is lower in German counties where historical antisemitism was higher, compared to otherwise similar counties. Households in counties with high historical antisemitism have similar saving rates but invest less in stocks, hold lower saving deposits, and are less likely to get a mortgage to finance homeownership after controlling for wealth and a rich set of current and historical covariates. Present-day antisemitism and supply-side forces do not fully explain the results. Households in counties where historical antisemitism was higher distrust the financial sector more - a potential cultural externality of historical antisemitism that reduces wealth accumulation in the long run.
\end{abstract}

JEL: D91, G11, J15, N90, Z10, Z12.

Keywords: Cultural Economics, Cultural Finance, Intergenerational Transmission of Norms, Stereotypes, Household Finance, History \& Finance.

*D'Acunto is at the R.H. Smith School of Business, University of Maryland (fdacunto@rhsmith.umd.edu). Prokopczuk is at Leibniz University Hannover and the University of Reading (prokopczuk@fmt.unihannover.de). Weber is at the Booth School of Business, University of Chicago and NBER (Michael.Weber@chicagobooth.edu). The views expressed in this paper do not reflect those of the DIW, the Bundesbank, GESIS, or the Banque de France. We thank the Editor, Nicola Gennaioli, and four anonymous referees for many excellent comments which helped improve the paper. We thank Joachim Voth and Nico Voigtlaender for making their data on anti-Jewish violence publicly available, Thomas Kick for his help with the Bundesbank data on county-level bank branches, the ifo-Prussian Economic History project, Michael Koetter for sharing his data on the efficiency of the local German banking system, and Martin Eisele for his great assistance in the access of the PHF Bundesbank data. In addition, we are indebted to ALLBUS and DIW Berlin for allowing us to merge their two proprietary data sources. In particular, we thank Andre Kastilan and Julia Klinger for creating measures of antisemitism at the county level from ALLBUS, and Jan Goebel for allowing the merging of these measures based on county identifiers to the SOEP. For very helpful comments and discussions, we thank Ran Abramitzky, Nick Barberis, Zahi Ben-David, Kelley Bergsma, Johannes Buggle, Davide Cantoni, Jason Chen, Pierluigi D'Acunto, Stefano DellaVigna, Barry Eichengreen, Ruben Enikolopov, Paola Giuliano, Rick Green, Tarek Hassan, Danling Jiang, Samuli Knupfer, Ross Levine, Sonya Lim, Dmitry Livdan, Ulrike Malmendier, Gustavo Manso, Petra Moser, Rabbi Adam Naftalin-Kelman, Terry Odean, Martha Olney, Christine Parlour, Chris Parsons, Caitlin Rosenthal, Paola Sapienza, Andrei Shleifer, Stephan Siegel, Andrei Simonov, Paul Smeets, Robert Vishny, Jason Wittenberg, Noam Yuchtman, and especially Luigi Guiso, Nico Voigtlaender, and Joachim Voth, as well as participants at several seminars and conferences. We also thank Stephen Lamb for excellent research assistance. All errors are our own. Weber acknowledges financial support from the Cohen Keenoy Faculty Research Fund at the University of Chicago Booth School of Business. 


\section{Introduction}

Financial development varies persistently across space, and this systematic variation might contribute to spatial inequalities, because households accumulate wealth through the stock market (Guiso, Sapienza, and Zingales (2004a)). Households' trust in the financial sector might help explain variation in the demand for financial services across space, including within countries whose regions have faced the same regulatory environment and the same financial institutions for decades (Gennaioli, La Porta, Lopez-de Silanes, and Shleifer (2013), Guiso, Sapienza, and Zingales (2009)). Measuring the size and determinants of trust in finance is challenging, because such determinants should persist for decades despite the implementation of institutional reforms and place-based policies.

A potential route to measure the spatial variation in households' trust in the financial sector is to exploit its origins in history, because inter-ethnic tensions can produce persistent anti-minority sentiment, which can survive the physical presence of minorities themselves (Voigtlaender and Voth, 2012). If different ethnic groups specialized in different economic activities in the past, ethnic tensions could lead one group to discriminate against the activity led by the other group. Parallel to the discrimination against minorities, discrimination against economic activities might persist even after ethnic specialization fades (Jha (2013), Grosfeld, Rodnyansky, and Zhuravskaya (2013), Jha (2014)), hence capturing the deeprooted variation in the localized trust in economic activities across space.

We build on this framework and test whether the historical specialization of Jews in financial services, paired with persistent historical antisemitism across space, helps explain the present-day regional variation in the demand for finance. Our analysis focuses on Germany - where Jewish persecution has persisted across space for centuries (Voigtlaender and Voth, 2012) - as an ideal laboratory. Crucially, the ethnic specialization of Jews in finance was an important component of historical antisemitism. It led to the emergence of negative stereotypes attached to Jews but unrelated to religious creed, which Reuveni and Wobick-Segev (2011) label "economic antisemitism." The baseline setting for our empirical tests is the Nazi period, which represented the most dramatic peak of economic antisemitism in Germany, because Jews were blatantly and unsubstantiatedly accused by the dictatorship of manipulating the German economy and causing economic depression "by means of their predominance in the stock exchange." ${ }^{1}$ Jewish persecution also arguably peaked during the Nazi period, when the dictatorship required the broader German population to persecute and delate Jews through widespread and pervasive propaganda.

\footnotetext{
${ }^{1}$ See Vol. I, chapter XI, of Hitler (1939) for a delirious interpretation of Jews as manipulators of the stock market.
} 
We document that present-day households in German counties with higher anti-Jewish sentiment during the Nazi period participate in the stock market less than other households. Figure 1 plots the negative correlation between stock market participation and historical antisemitism at the county level conditional on a large set of historical and present-day observables. Present-day households in counties where historical antisemitism was one standard deviation higher are about $9 \%$ less likely to hold stocks. The size of this association is similar to the effect of holding a college degree, and college education is one of the most studied determinants of stock market participation (van Rooij, Lusardi, and Alessie, 2011).

\section{Figure 1: Historical Antisemitism and Present-Day Stock Market Participation}

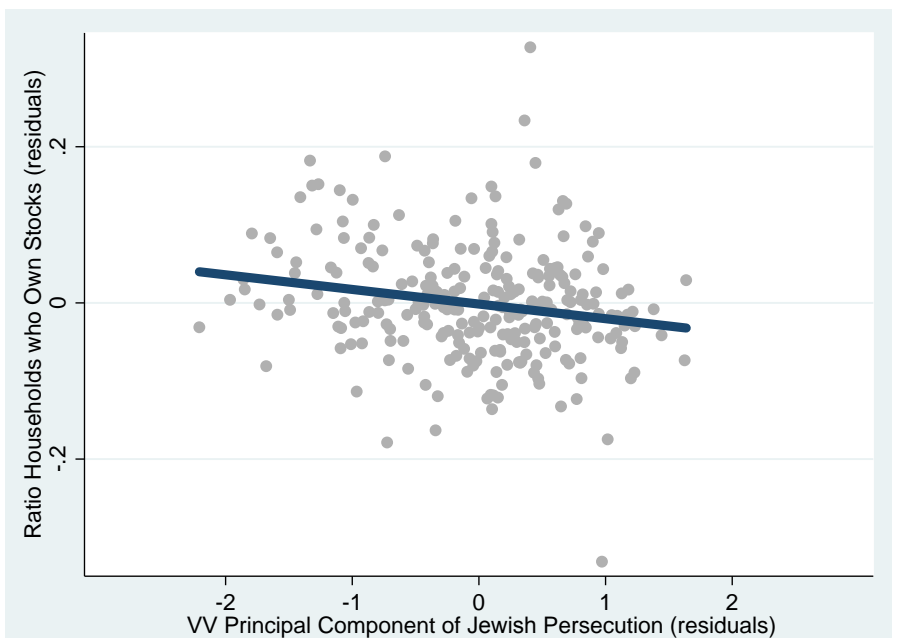

Each point is a German county. The vertical axis plots the residuals from estimating the following equation,

Ratio Stockholder $s_{k}=\alpha+K_{k}^{\prime} \times \delta+\epsilon_{k}$,

where $K_{k}$ is the set of historical and present-day observables described in section 3. The horizontal axis plots the residuals of a regression of the Voigtlaender-Voth (VV) principal component of Jewish persecution in the 1920s and 1930s, which is our main measure of historical antisemitism (see section 3.A), and the same set of covariates $K_{k}$.

The baseline association between local historical antisemitism and stock market participation by present-day German households is a robust feature of the data, and survives a large set of robustness tests, such as restricting the geographic variation we use in the analysis and using alternative proxies for local antisemitism during the Nazi period.

Although the defamation of Jews as stock market manipulators was salient in the press and popular culture even after the Jewish presence in banking had faded after the spread of credit unions and public savings banks at the end of the $18^{\text {th }}$ and early $19^{\text {th }}$ centuries (Köhler, 2005), historians documented a stereotype of Jews as moneylenders and bankers that was common in the German lands for centuries. The Jewish ethnic specialization in the provision of financial services was the main driver of this stereotype, and was largely driven by the fact that Christians were banned from lending money at interest throughout the Middle Ages. Consistent with the stereotype of Jews as moneylenders, we find historical antisemitism during the Nazi period is also negatively associated with households' use of 
banking services today. Households in counties with higher historical antisemitism are $10 \%$ less likely to have a mortgage, but as likely as other households to own a house. The ratio of retail deposits over total assets of the banks in counties with higher historical antisemitism is $2 \%$ lower than in other counties, even if saving propensities and the concentration of bank branches do not differ systematically across counties. We also find suggestive evidence that households in counties with higher historical antisemitism hold a larger fraction of their wealth in cash.

Several channels, both on the demand side and the supply side, might explain our baseline results. We therefore exploit our setting further by focusing on our historical approach. To further disentangle the hypothesis that historical antisemitism relates to present-day financial decisions from other explanations related to localized economic shocks during the Nazi period, we build on the fact that the spatial variation in historical antisemitism within Germany has persisted for centuries since the Middle Ages (Voigtlaender and Voth, 2012). We test whether deep-rooted measures of historical antisemitism based on the violence against local Jewish communities during the Black Death of 1349 can predict the present-day stock market participation of German households similar to antisemitism during the Nazi period. Indeed, households in counties that persecuted the local Jewish communities more as far back as in the Middle Ages are less likely to invest in stocks today, and the mere presence of Jews in a county in the distant past does not explain the effect.

To assess the remaining concerns that unobservable dimensions not captured by our controls and robustness tests drive both historical antisemitism and present-day financial development, we exploit a historical natural experiment (D'Acunto, 2016). We instrument the probability that a county engaged in Jewish persecution in the past with its distant from the Rhine Valley, which captures the paths of forced migrations of the first Ashkenazi communities because of the Crusades. This test confirms our baseline results.

In the last part of the paper, we study a set of potential supply- and demand-side channels that might have transmitted the effect of historical antisemitism to present-day financial development.

On the supply side, we note that all German counties have faced the same financialsector regulation since the $19^{\text {th }}$ century, ${ }^{2}$ but locally-run independent financial institutions are still an important pillar of the German banking system. Historical antisemitism might have triggered the establishment of local banks of different quality and efficiency across counties. We find the present-day supply of finance and the present-day efficiency of the local banking sector do not vary systematically with historical antisemitism. We therefore

\footnotetext{
${ }^{2}$ Eastern German counties during the Cold War are an obvious exception, but the shock of facing a communist economic system is exogenous to the spatial variation of historical anti-Jewish sentiment.
} 
conclude that the present-day local supply of financial services cannot fully explain our results.

Alternatively, economic antisemitism might have worsened the historical local supply and efficiency of financial services. Even if these differences in supply had disappeared over time, present-day households might still be less accustomed to accessing financial services in counties with higher historical antisemitism. We collect data on the supply of financial services in the past, which we can measure at the county level in the $19^{\text {th }}$ century, and we do not find evidence that this channel is relevant to our results.

On the demand side, we first test whether present-day households that are antisemitic might still associate financial services with Jews, and thus invest less in stocks and demand fewer financial services. We test this channel using data on present-day antisemitism at the county level. We find that present-day antisemitism and stock market participation are negatively associated, as predicted by the long-term persistence of local antisemitism (Voigtlaender and Voth, 2013). At the same time, however, we find no association between present-day antisemitism and stock market participation after controlling for historical antisemitism. Our measures of historical antisemitism are arguably subject to higher measurement error than the measures of present-day antisemitism, and hence this test should bias us towards detecting an effect of present-day antisemitism on top of historical antisemitism even if such an autonomous effect did not exist. Thus, the results suggest the variation in antisemitism produced in the last decades has no role in explaining the present-day demand for finance.

Apart from present-day antisemitism, historical anti-Jewish sentiment might correlate with other retrograde beliefs such as xenophobia, racism, or distrust of the unfamiliar, which we label collectively "backwardness." Using county-level data on present-day xenophobic beliefs, we propose a set of tests that suggest our results are not consistent with these alternative demand-side channels.

Motivated by Gennaioli, Shleifer, and Vishny (2015), we move on to test for the possibility that a persistent cultural norm of distrust in finance, transmitted across generations, has developed more in counties in which historical antisemitism was stronger. Past households in counties with higher antisemitism might have developed a negative sentiment toward the economic activity in which Jews specialized, namely, financial services. This sentiment might have persisted to the present day even if its underlying determinants-specifically, the discrimination against Jews and the association of Jews with financial services-have faded.

We use novel survey data on a representative sample of 1,000 present-day Germans 
to elicit their distrust in finance. ${ }^{3}$ The survey also elicits measures of risk tolerance and generalized trust at the individual level, both of which are strong determinants of stock market participation (Guiso et al. (2009)). Indeed, present-day distrust in finance is higher for respondents in counties with higher historical antisemitism, even after controlling for their risk tolerance and average generalized trust. Consistent with a relevant role of this channel in explaining our results, households that distrust finance more also report they invest less in stocks and bonds.

Several theoretical channels, which we discuss in more detail in section 7 , are consistent with our results and interpretation. Overall, our findings suggest historical antisemitism in the form of economic antisemitism (Reuveni and Wobick-Segev, 2011) might have started a norm of distrust in finance, which has transmitted across generations and manifests itself in lower present-day demand for finance.

\section{A Related Literature}

This paper builds on several strands of literature. First, we build on the literature that studies the non-institutional determinants of the spatial variation of economic development. Banfield (1958) and Putnam (1993), who emphasize the importance of demand-side factors, such as social capital and generalized trust, in explaining persistent localized differences in development. Guiso et al. (2004b) and Algan and Cahuc (2010) investigate these determinants of present-day financial development and economic growth. Gennaioli et al. (2013) use data from 110 countries covering 97\% of the world GDP to show human capital is crucial in accounting for regional differences in development. This literature has introduced measures of present-day social capital and trust, and has documented the robust association between these dimensions and financial development. Our contribution to this literature is to propose a determinant of local demand-side characteristics that is not prone to the concern of reverse causality because of its deep-rooted nature.

Second, we build on recent research documenting the long-run persistence of discrimination due to historical inter-ethnic tensions. Voigtlaender and Voth (2012) and Voigtlaender and Voth (2013) show that localized historical anti-Jewish sentiment persisted for centuries and can still be detected today. Anderson, Johnson, and Koyama (2017) show that low agricultural yield explains the time-series and spatial variation of pogroms against Jews across Europe from 1100 to 1800. Grosfeld, Sakalli, and Zhuravskaya (2017) argue economic specialization combined with negative shocks was crucial to the emergence of pogroms against Jews. Becker and Pascali (2017) argue the Protestant Reformation led

\footnotetext{
${ }^{3}$ We thank Stefano DellaVigna and Noam Yuchtman for inspiring this test.
} 
to the entry of non-Jews in moneylending, which reduced the incentives to persecute Jews.

Previous work shows persistent anti-minority sentiment due to historical inter-ethnic tensions might be rooted in the historical economic specialization of ethnic groups. Jha (2014) shows that areas in Gujarat that enjoyed inter-ethnic economic complementarity in the past were less likely to engage in ethnic violence in 2002. Grosfeld et al. (2013) show a positive effect of the Pale of Settlement-a region of present-day Ukraine in which Jews were confined-on post-Soviet electoral support for left-wing parties and on generalized trust. Our results cannot reflect the generic anti-market beliefs studied by Grosfeld et al. (2013). In untabulated results, we find no effect of historical antisemitism on the electoral support for left-wing parties of present-day Germans. Moreover, Grosfeld et al. (2013) find a positive association between generic anti-market beliefs and generalized trust. Generalized trust increases households' likelihood of demanding financial services (Guiso et al., 2009). Hence, if the anti-market beliefs proposed by Grosfeld et al. (2013) explained our results, we should detect a positive effect of historical anti-Jewish sentiment on households' demand for financial services, which is the opposite of what we find. We see our demand-side results as complementary to recent work on the supply-side effects of Jewish persecution (e.g., Acemoglu, Hassan, and Robinson (2011), Waldinger (2010), Akbulut-Yuksel and Yuksel (2015)).

An additional contribution of our paper is to bring together the two lines of research described above. The first literature has focused mainly on documenting the role of presentday determinants in explaining present-day regional differences. The second literature has focused mainly on establishing the long-run persistence of political and sociological beliefs. Our paper builds on both approaches to study the deep-rooted determinants of present-day variation in economic outcomes and the channels through which these determinants affect present-day economic outcomes. This step is relevant also as a basis for informing policy makers about the demand- and supply-side dimensions on which they might intervene to modify households' economic behavior.

The paper also relates to the body of research that uses historical natural experiments to understand present-day outcomes, surveyed by Spolaore and Wacziarg (2013) and Nunn (2014). For the case of financial outcomes, D'Acunto (2016) labels this nascent approach "History \& Finance." Recent contributions include Pascali (2016), who shows Jewish-managed banking in Southern Italy triggered the establishment of competing Christian financial institutions, whose influence on financial development is detectable today. Pierce and Snyder (2017) find that firms in African countries with higher historical extraction of slaves face lower access to formal and informal credit, whereas D'Acunto (2017) shows 
that spatial variation in basic education has persisted for centuries, and helps explain the present-day regional differences in income and innovation across European regions.

Finally, we contribute to the literature on the stock-market-participation puzzle-the fact that many households do not actively invest in stocks despite the high expected returns in the stock market. Other explanations include background risk (Paxson (1990), Guiso, Jappelli, and Terlizzese (1996)), social interactions (Hong, Kubic, and Stein (2004)), awareness (Guiso and Jappelli (2005)), generalized trust (Guiso et al. (2009)), insurance motives (Gormley, Liu, and Zhou (2010)), financial literacy (van Rooij et al. (2011)), macroeconomic experiences (Malmendier and Nagel (2011)), labor-income risk (Betermier, Jansson, Parlour, and Walden (2012)), and corporate scandals (Giannetti and Wang (2016)).

\section{Jewish Specialization in Finance and Historical Antisemitism}

Our analysis is based on two features of the history of Jewish minorities across Europe since the Middle Ages. On the one hand, Jews had specialized in the provision of financial services after the fall of the Roman Empire. The sorting of Jews into the mercantile and financial sectors started around the eighth century, largely because of their human capital and their tradition in contract enforcement (Botticini and Eckstein (2012)).

Bans on lending money at interest for Christians and Muslims may have contributed to crystallizing this sorting. Pope Leo IX banned Christians from lending money at interest as far back as 1049, and Gratian formalized the ban in the Corpus Iuris Canonici in 1150. The human capital Jews had accumulated since the second century facilitated their sorting into trade and finance well before 1049. At the same time, an important push for the specialization of Jews in financial services and trade came also from the contemporaneous bans on owning land Jewish communities faced, which were common all over Europe during the Middle Ages (e.g., see Roth (1938) and Roth (1960)).

Financial activities run by Christians, such as the Medici family in Italy or the Fuggers family in the German lands, were active since the $15^{\text {th }}$ century. In the German lands, the oldest non-Jewish full-service bank, called Berenberg Bank, was founded in 1590. Despite these cases, the Catholic Church maintained a formal ban on usury for centuries. For instance, Pope Benedict XIV condemned firmly the sin of usury in his encyclical letter "Vix Perveni" of 1745. At the same time, the specialization of Jews in finance persisted even after the elimination of the ban on moneylending for all Christian denominations. For instance, in 1882, $3 \%$ of German workers were Jewish, but $23 \%$ of the overall financial sector workforce, and more than $85 \%$ of the brokers in the Berlin stock exchange, were Jewish (see 
Glagau (1876) and Fritsch (1892)). ${ }^{45}$ The drop in Jewish specialization in financial services was mainly driven by the diffusion of local private credit unions such as the Raiffeisenbanken and the Volksbanken, as well as the saving-bank system known as Sparkassen, which were owned and run by local governments. Both types of banks diffused swiftly throughout the German lands in the $19^{\text {th }}$ century and the beginning of the $20^{\text {th }}$ century.

Localized inter-ethnic tensions and outright violence against Jews also accompanied European Jewish communities since the Middle Ages. On top of religious antisemitism, the Jewish specialization in trading and finance led to the emergence of "economic antisemitism," that is, a set of negative stereotypes related to the role of Jews in the economy (Reuveni and Wobick-Segev, 2011).

To date, the historiography of economic antisemitism is still debating the relationship between economic antisemitism and the discrimination and persecution of Jewish communities over the centuries. In particular, the debate is still open on whether violence against religious minorities existed beyond the minorities' occupational specializations, or whether hatred toward specific occupations led to the persecution of ethnic minorities that specialized in those occupations. Penslar (2001) argues the distrust of trade and the mercantile economy has roots in ancient Greece and Rome, and translated into distrust of Jews once Jewish communities sorted into running financial services. In sociology, Bonacich (1972), Bonacich (1973), and Horowitz (1985) propose a theory of ethnic tensions deriving from the specialization of ethnicities in different economic occupations. Ethnicities specializing in middlemen activities are especially prone to being subject to inter-ethnic violence.

Other historians argue the motivations for Jewish persecutions in Europe were at first mainly cultural, political, and religious (e.g., see Flannery (1985)). This position is based on the observation that the first recorded acts of violence against Jews, such as the Alexandria pogrom in $38 \mathrm{CE}$, happened when Jews had not yet sorted into the mercantile and financial sectors (Barclay (1996)). Historians who support the non-economic roots of the early instances of persecution against Jewish minorities argue that the hatred against Jews as economic exploiters of the Christian majority appeared at a later stage (e.g., Poliakov (1975) and Perry and Schweitzer (2002)).

\footnotetext{
${ }^{4}$ Table A.6 of the Online Appendix reports the share of Jewish workers across sectors in 1882 Germany.

${ }^{5}$ Gross (1975) argues that Jewish brokers started the Berlin stock exchange and enjoyed a monopoly on brokerage activities, to the extent that the few non-Jewish brokers would not work on Saturdays, because of the lack of traders, even though the market was open.
} 


\section{Data}

Our tests require that we define proxies for local historical antisemitism across German counties, and that we assess the association between historical antisemitism and the likelihood that present-day households access financial services.

\section{A Measures of Historical Antisemitism}

We propose three proxies for historical antisemitism. The first and main proxy is the first principal component of six measures of anti-Jewish violence in Voigtlaender and Voth (2012). The measures cover several types of acts of violence perpetrated against local Jewish communities in Germany in the 1920s and 1930s, which includes the Nazi period. The variables that enter the Voigtlaender-Voth principal component (VV P.C.; Historical Antisemitism) are as follows: (i) the number of documented pogroms, that is, recorded acts of physical violence, against Jewish communities in the 1920s based on the information in Alicke (2008); (ii) the share of votes for the far-right and strongly antisemitic Deutschvölkische Freiheitspartei (DVFP) in 1924, which obtained a large share of the then-banned Nazi Party (NSDAP), based on the election data in Falter and Hänisch (1988); (iii) the share of votes for the NSDAP in 1928, which is also based on the data in Falter and Hänisch (1988); (iv) the logarithm of the number of "letters to the editor" published by the Nazi newspaper Der Stürmer from 1935 to 1938; (v) the share of Jews deported in 1933; and (vi) a dummy variable that equals 1 if a synagogue was destroyed or damaged in the 1920s and 1930s in the location. We consider the authors' extended sample of cities, which include all cities with Jewish communities during the Weimar Republic. The only difference between the original version of the VV P.C. and the one we use in this paper is the level of aggregation of the information. Voigtlaender and Voth (2012) compute their variables at the city level, which we cannot do in this paper, because the finest geographic partition for which we observe financial data of present-day households is county (Kreis). We therefore compute the principal component by aggregating the city-level variables at the county level. Aggregation consists of summing up the count variables (number of pogroms in the 1920s and number of letters to Stürmer), averaging the share variables (share of DVFP votes in 1924, share of NSDAP votes in 1928, and share of Jews deported in 1933), and defining a dummy variable equal to 1 if a synagogue was destroyed or damaged in the 1920s and 1930s in any city within a county.

We also propose two additional proxies for our analysis that aim to capture localized and deep-rooted historical antisemitism at the time when Jews still had the monopoly on 
the provision of financial services. One proxy, Pogrom 1349 (Medieval Antisemitism), is also based on observed violence against Jewish communities. It is a dummy that equals 1 if any town in the county experienced at least one anti-Jewish pogrom during the years of the Black Death around 1349. The Black Death was arguably the worst pandemic in human history, and up to one half of the European population at the time may have died. Unsubstantiated theories on the origins of the pandemic diffused all over Europe. Accusations against Jews were common and led to persecution, especially in the German lands. Voigtlaender and Voth (2012) find the incidence of pogroms during the Black Death period predict the extent of Jewish persecution during the 1920s and 1930s at the town level. Similar to the principalcomponent measure, the level of resolution of our financial data dictates that we depart from the city-level analysis.

Our third proxy for historical antisemitism is the mere presence of a Jewish community in each county at any point in time before 1300. This measure aims to capture the possibility that historical antisemitism arose in counties even if it did not necessarily express itself through pogroms or major acts of violence against Jews. This measure also allows us to assess separately the effects of exposure to Jews before the Black Death period and the actual explosion of anti-Jewish tensions at the time of the Black Death.

The two medieval proxies allow us to track the origin of historical persecution, but the variation in these dummy variables is rather coarse. At the same time, the proxy from the Nazi period allows for a more granular variation across counties and occurs at a time when the association of Jews with the stock market, our main outcome variable, was strongest. For alternative sources of variation in anti-Jewish sentiment during the Nazi period, see the discussion in section 1 of the Online Appendix.

\section{$B$ Other Data Sources}

To run the tests in this paper, we collect data from 13 additional sources.

The characteristics of German households are from the Socio-Economic Panel (SOEP) run by the Deutches Institut für Wirtschaftsforschung Berlin (DIW). The SOEP has conducted interviews on a yearly basis since 1984. For each wave, the SOEP includes households that have been interviewed in previous waves, as well as new households. Because we are interested in the cross-sectional association between historical antisemitism and financial development, we only include non-repeated observations when running the main analysis. A drawback of the SOEP data is that they do not provide the complete financial portfolios of households; hence, we cannot document how anti-Jewish sentiment affects every component of households' financial portfolios. Moreover, the SOEP data set does not include 
measures of the household head's risk aversion, financial literacy, or generalized trust, which the literature on stock market participation identifies as important determinants for investing in stocks.

To address these shortcomings of the SOEP data, we show our results are robust to using the balance sheets of the German households in the 2011 wave of the Panel of Household Finances (PHF) run by the Deutsche Bundesbank. We can match the PHF sample with the historical data for 1,256 households across 99 counties, and hence this data set is too small to be our main working sample. But in the PHF data, we can control directly for households' wealth, as well as the elicited risk aversion, financial literacy, and generalized trust of household heads. To test for the effects of historical antisemitism on present-day bank deposits, we collect information on German banks' balance sheets from Bankscope.

We obtain county-level historical characteristics from the Ifo Prussian Economic History Database, described in detail by Becker, Cinnirella, Hornung, and Woessmann (2014). We also collect a set of present-day county-level controls: socio-demographics from DeStatis; the index of land quality from Ramankutty, Foley, Norman, and McSweeney (2002); and the coordinates of the centroid of each county from Eurostat, which we use to measure the Euclidean distance of each county from the Rhine Valley in our distance-based three-stage least-squares test we describe below. We construct a placebo test on the association between the distance from the Rhine Valley and stock market participation for French households to the West of the Rhine, using the micro data underlying the 2014 Enquete Patrimoine run by the Banque de France, which provides geo-coded information on the investment decisions of a representative set of present-day French households.

To assess the association between present-day antisemitism and financial development, we use data on present-day antisemitism at the county level from the German Social Survey ( $A L L B U S)$, which gathered information on Germans' attitudes toward Jews in 1996 and 2006. The data are described in detail in Voigtlaender and Voth (2013). We also use the ALLBUS data on present-day xenophobic attitudes to differentiate the role of antisemitism from generic xenophobia. To use these data, we arranged a special agreement between ALLBUS and DIW to merge these two proprietary data sources. Moreover, we use the micro data underlying the World Value Survey's 2006 wave, in which households were asked about the importance of religion for their life, and other questions related to religiosity. This survey allows us to create regional-level measures of the importance of religion to present-day households irrespective of their creed or denomination.

In the analysis of the channels that transmitted the long-run association between localized historical antisemitism and financial decisions, we also introduce three sources of 
data that are in large part new to research in economics: (i) data on the market structure, competition, and efficiency in German banking at the county level from the German Council of Economic Experts ${ }^{6}$-an advisory institution to the German administration similar to the US Council of Economic Advisers (see Koetter (2013)); (ii) data on the foundation dates of German's Volksbanken and Raiffeisenbanken from the Hoppenstedt database, which allow us to construct the spatial-diffusion pattern of credit unions across the German lands in the second half of the $19^{\text {th }}$ century; and (iii) our own survey aimed at eliciting present-day German households' distrust in financial services. We ran the survey through the company Clickworker because we are not aware of any data on a representative set of German households regarding their trust in financial services. We describe the survey design and characteristics in more detail in section 7 . These data include elicitation of several types of financial beliefs and attitudes, and are publicly available to any authors interested in their use.

\section{Summary Statistics}

The full sample of non-repeated households in the SOEP county-level data set includes 29,680 observations. The county of residence is not available for 2,655 households. Moreover, we are missing the county-level historical information for 9,207 households. The remaining missing observations are due to refusal to answer demographic questions, such as the income or age of the household head.

We report the basic summary statistics for the variables in the main analysis in Table 1. The top panel of Table 1 describes the measures of historical antisemitism at the county level. We observe the emergence of pogroms during the Black Death and a county's exposure to Jewish communities before 1300 in 307 counties, whereas we can compute the VV P.C. of Jewish persecution for 298 counties. During the Black Death period, $54 \%$ of counties faced a pogrom against the local Jewish community, whereas $92 \%$ of the counties were exposed to local Jewish presence at least once before 1300. In the regression analysis, we assign the county-level value of each variables to all SOEP households residing in the county.

The middle panel of Table 1 reports the other observables measured at the county level, whereas the bottom panel describes household-level variables. The average fraction of households owning stocks between 1984 and 2011 is 16\%. The average age of the person who makes financial decisions is 49 years. Thirty-nine percent of responding households are homeowners, and the average self-reported income is 31,355 euros. The SOEP survey does

\footnotetext{
${ }^{6}$ The original label of this institution is Sachverständigenrat zur Begutachtung der gesamtwirtschaftlichen Entwicklung, which is also referred to as the five wise men of the German economy (Fünf Wirstchaftensweisen).
} 
not ask households for an estimate of their overall wealth. We use income and homeownership to proxy for wealth. About $77 \%$ of responding households have a high school degree or higher levels of education. Moreover, about $13 \%$ of the households we observe reside in Eastern Germany. ${ }^{7}$

Figure 2 depicts the properties of historical antisemitism and present-day stock market participation at the county level. To allow easier interpretation of the magnitudes and variation of historical antisemitism in the cross-section of counties, we consider the ratio of the local Jewish population as of 1933 that was deported during the Nazi period as a proxy for historical antisemitism. Panels (a) and (b) of Figure 2 show the spatial distribution of the share of the deported Jewish population during the Nazi period and of the average ratio of households that own stocks from 1984 to 2011. In both maps, the darker the county, the higher the value of the variable. The data are not available for blank counties. Relative deportations of Jews during the Nazi period were higher in western counties. Stock market participation is higher in the south and in the north. As expected, participation is systematically lower in Eastern Germany. Panels (c) and (d) of Figure 2 plot the densities of the ratio of deported Jews, which obtains over the full range of $[0,100]$, and present-day stock market participation, both measured at the county level. Panel (e) plots the correlation between the ratio of deported Jews and the average ratio of households that own stocks from 1984 to 2011, which is negative $(-0.13$, p-value=0.03). Note Panel (e) corresponds to the figure we reported in the Introduction, but we replace the VV P.C. of Jewish persecution with the ratio of Jews deported during the Nazi period. Panel (f) of Figure 2 shows the average participation across counties with and without pogroms during the Black Death. Participation is higher in counties with no pogroms, but a t-test for the difference between the two means does not reject the null that the means are equal. We find the negative, although statistically insignificant, association between experiencing a pogrom around 1349 and present-day stock participation encouraging. Of course, the non-significant difference in stock market participation in the raw data might reflect substantial variation in important determinants of participation across counties, such as income, age, or education, which is why we can only assess the precision of this negative association by running a multivariate analysis that keeps constant other determinants of participation across counties.

The Online Appendix describes additional characteristics of the raw data. Figure A.1 shows the spatial distribution of pogroms against Jews during the Black Death. In Figure A.2, we plot the correlations between stockholdings and additional proxies for historical antisemitism in the raw data, all of which are negative.

\footnotetext{
${ }^{7}$ Note that we only observe information for Eastern-German households starting in 1991.
} 


\section{Historical Antisemitism and Stock Market Participation}

In the baseline analysis, we estimate the association between historical antisemitism measured at the county level and stock market participation by German households from 1984 to 2011. The following is our most general specification:

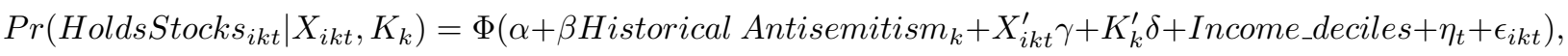

where HoldsStocks $s_{i k t}$ is a dummy that equals 1 if household $i$ in county $k$ and surveyed in wave $t$ holds any stocks, and Historical Antisemitism is $_{k}$ is one of the proxies for historical antisemitism we describe in section 3. $X_{i k t}$ includes the following individual-level controls: gender, single status, age (second-degree polynomial), and dummies for college education, homeownership, and investment in life insurance. $K_{k}$ includes the following county-level current and historical controls: latitude, income per capita, share of college-educated population, index of quality of cultivable land, log of population in 1933, log of Jewish population in 1933, share of population employed in the retail sector in 1933, share of population employed in manufacturing in 1933, and share of Catholic population in 1925. Income_deciles are dummies indicating the decile of the income distribution to which the household belongs, and $\Phi$ is the standard normal cdf. ${ }^{8} \eta_{t}$ are a set of survey-wave group fixed effects, each capturing a group of four adjacent years. ${ }^{9}$ We allow for correlation of unknown form across residuals at the county level, because attributing county-level measures to each household induces a mechanical correlation of residuals across households in the same county.

Table 2 reports the average marginal effects for our baseline specification. All the variables are standardized, with the exception of dummy variables. Columns (1)-(2) report the results for the baseline specification on the full sample. In column (1), we only include the logarithm of the number of Jews residing in each county in 1933 to scale the persecution measure by the size of the local Jewish community, and hence the scope for persecution, on the right-hand side. A one-standard-deviation increase in the VV P.C. (1.02) is associated with 0.9-percentage-point-lower stock market participation. In column (2), we add the full set of historical and present-day controls, a dummy that equals 1 for households in Eastern Germany, and survey-wave group fixed effects. Adding this set of controls increases the size of the negative association between historical antisemitism and stock market participation to 1.4 percentage points. Because the average stock market participation rate in our sample is $16 \%$, this association corresponds to about $9 \%$ of the average participation.

\footnotetext{
${ }^{8}$ All the results are virtually identical if we include second- or third-degree income polynomials instead of deciles.

${ }^{9}$ Results do not change if we make the survey-wave fixed effects coarser or finer.
} 


\section{A Robustness}

German counties are likely to differ along several dimensions, such as geography, history, and the quality of current and historical institutions. For these reasons, in the rest of the Table 2, we assess the robustness of the baseline negative association between historical antisemitism at the county level and the likelihood that present-day households living in those counties participate in the stock market today.

We first verify that the baseline results hold when only considering counties in West Germany. Note that the baseline specifications already include a dummy variable for whether a county was part of Eastern Germany after the Second World War, but one might still be concerned about systematic non-linear differences in the effect across the two areas. In column (3) of Table 2, we find our results do not change if we look only at Western counties.

In our second test, we add the longitude of the counties' centroids to the baseline specification as a direct control. This control is motivated by the fact that important shocks related to counties' longitude had differential long-run effects on the growth of German regions. For instance, Acemoglu, Cantoni, Johnson, and Robinson (2011) show that institutions imposed by the French on German areas closer to the French border after the French Revolution had a long-run effect on growth through their effect on institutions. In column (4) of Table 2, we find our results are similar if we include longitude explicitly as a control in the baseline specification. Note that the shocks that had long-run effects on growth and were correlated with longitude happened after the Black Death of 1349. Such shocks then would only be able to explain the results if their geographic dispersion were highly correlated with the geographic distribution of medieval pogroms.

Finally, in columns (5)-(8) of Table 2, we exclude groups of counties, which perform worst based on economic indicators in the present day. In column (5), we exclude the bottom quarter of counties by population density and hence the most rural counties; in column (6), we exclude the top quarter of counties by income inequality; in column (7), we exclude the bottom quarter of counties by average income and hence the poorest counties; and in column (8), we exclude the bottom quarter of counties by share of college-educated inhabitants and hence the least educated counties. Across all subsamples, we do not detect substantial differences compared to our baseline results.

We propose additional robustness tests in Table A.1 and Table A.2 of the Online Appendix, and confirm the negative association between historical antisemitism and presentday stock market participation is a robust feature of the data. 


\section{$B$ Alternative Samples and Sources of Variation}

The SOEP sample does not allow us to keep constant dimensions that previous research has shown to be important determinants of financial decision-making. Prior research shows financial literacy (van Rooij et al., 2011), risk aversion (Samuelson, 1969), and household wealth are first-order determinants of stock market participation. Moreover, an important determinant of historical antisemitism could be households' religiosity, which might have also persisted over time irrespective of households' religious denomination, and hence might confound our interpretation of the baseline results.

To assess the extent to which any of these dimensions might explain our results, we replicate the cross-sectional analysis on the German households in the 2011 wave of the Panel of Household Finances (PHF). The size of the PHF sample is more than one order of magnitude lower than the SOEP sample, and we can only exploit the variation in Jewish persecution across 99 German counties for which we have both historical data on persecution and PHF observations. For these reasons, we cannot use the PHF sample as the main sample in our analysis, but we believe it provides a useful alternative data set to assess the robustness of our baseline results. The PHF questionnaire asks households to provide an estimate of their overall wealth. It also elicits households' financial literacy and risk aversion using qualitative scales, as well as the frequency with which respondents attend religious functions, irrespective of their religious denomination.

All the results based on the PHF sample are reported in Table A.3 in the Online Appendix. In column (1) of Table A.3, we replicate our baseline results by estimating the specification in equation (1) and augmenting the right-hand side with direct measures of financial literacy, risk tolerance, and the religiosity of the respondent, as well as a full set of dummies for wealth deciles. As expected, the measures of risk tolerance and financial literacy are positively associated with the likelihood of holding stocks, on top of the effect of being male and holding a college degree. We estimate a larger negative association between historical antisemitism and the likelihood that respondents hold stocks in the PHF sample than in the SOEP sample, even after controlling for additional important determinants of stock market participation. One-standard-deviation-higher historical antisemitism in the county decreases the likelihood that the household owns stocks by 7 percentage points, which is about $24 \%$ of the average likelihood of holding stocks in this sample. The likelihood of holding stocks in the PHF sample is $29 \%$, which is similar to the likelihood of holding stocks for the SOEP households in the 2010 wave (28\%).

In section 1 of the Online Appendix, we also propose an alternative test to address the concern that historical persecution against Jews might have been perpetrated due to 
incentives unrelated to antisemitism. For instance, individuals and political leaders may have hoped to seize Jewish property if they took part in or promoted the attacks against Jews, which would have affected historical persecution against Jews as well as the long-run wealth of local households.

The test exploits political support for the Nazi party as an alternative proxy for historical antisemitism, because antisemitism was a major pillar of the Nazi party's ideology in the late 1920s and early 1930s. But motivations other than antisemitism contributed to the political support for the Nazi party. In particular, the prolonged economic recession that hit Germany after 1929 was famously a major determinant of Nazi support. We therefore conjecture that voting support for the Nazi party should be a more direct proxy for antisemitism in counties in which unemployment was lower than the national average, whereas it should be a noisier proxy for antisemitism in counties in which unemployment was high, and hence motivations other than antisemitism might have increased Nazi votes. Armed with this interpretation, we estimate the effect of county-level Nazi votes in the general elections of September 1930 and of 1933 on present-day stock market participation.

Consistent with our conjecture, we find Nazi votes are strongly negatively associated with present-day stockholdings in counties at the bottom of the distribution by unemployment, whereas this association stays negative but smaller in size and statistically insignificant for counties at the top of the distribution by unemployment. The negative association declines monotonically as the share of a county's unemployment decreases, as depicted in Figure A.3 of the Online Appendix. Contrary to Nazi votes, all the other dimensions we measure at the county level in the early 1930s do not produce the pattern described above, including the vote shares for non-antisemitic parties (see Figure A.4 and discussion in Section 1 of the Online Appendix).

These results corroborate our baseline analysis by using a different source of variation and proxy for historical antisemitism than the ones we used above.

\section{Historical Antisemitism and Banking: Mortgages and Deposits}

So far, we have focused on the likelihood that German households hold stocks. Focusing on stock market participation is meaningful, because the defamation of Jews as stock-market manipulators survived in the press and popular culture even after the Jewish presence in other financial institutions, such as banking, had faded. The role of Jews in banking services started to decrease substantially with the foundation of the first Raiffeisenbank in 1843 and the subsequent diffusion of Volksbanken across German counties. Several generations 
of Germans have accessed banking services run by the non-Jewish population. But if the historical association between Jews and financial services affects current financial decisions through channels other than current antisemitism, we would expect also to find an effect of historical antisemitism on present-day Germans' access to banking services.

We first look at the decision to get a mortgage to finance homeownership. This decision allows us to observe whether households increase their debt through bank financing, or if they use their own savings, keeping constant the likelihood that they are homeowners. For the case of Germany, looking at this margin is quite relevant: in 2001, $43 \%$ of German households owned their home, but only $20 \%$ of households have ever held mortgages; that is, only $47 \%$ of homeowners had financed their homeownership via a mortgage (Georgarakos et al. (2010)). In Table 3, we find that historical antisemitism is unrelated to households' decision to buy their home, but it significantly decreases the likelihood that households hold a mortgage. In columns (1)-(2), we report the coefficients for estimating two probit specifications whose outcome variable is a dummy equal to 1 if the household owns any real estate properties. The effect of antisemitism on the likelihood of homeownership is economically and statistically insignificant. In columns (3)-(4), we report the coefficients for the same specifications, but now the outcome variable is a dummy equal to 1 if the household has ever held a mortgage. A one-standard-deviation increase in historical antisemitism reduces the likelihood of holding a mortgage by 0.7 percentage points, which is $10 \%$ of the average likelihood of holding mortgages in our sample $(6.9 \%) .{ }^{10}$ The size and statistical significance of this association are in line with the effect of antisemitism on present-day stockholdings, which we documented above.

The second decision that relates households to banking services is their likelihood of saving through bank deposits. In the SOEP data set, we observe whether households declare that they regularly save part of their income. Reassuringly, in columns (5)-(6) of Table 3, we find historical antisemitism is unrelated to the likelihood that the households in our sample declare they regularly save part of their monthly income. This non-result suggests households in counties with higher or lower historical antisemitism do not differ in their wealth or overall saving behavior. Ideally, we would like to observe the share of households' savings in bank deposits. Unfortunately, we do not observe this information in the SOEP sample. Our second source of household-level data, the PHF, does include information on whether households declare they have a checking/ savings account. We find that $99.35 \%$ of respondents declare they have a checking/ savings account, which does not provide us with enough variation in this outcome to compare the behavior of households

\footnotetext{
${ }^{10}$ The average in our cross section of households observed from 1984 to 2011 is lower than the average for the cross section of households studied by Georgarakos et al. (2010), which are all observed in 2001.
} 
across counties with different levels of historical antisemitism. Because aggregate deposits of bank customers appear as liabilities in the balance sheets of banks, we can use aggregate data on the ratio of deposits to total assets for the banks that operate in each county. We obtain this information from Bankscope, and we regress this ratio on historical antisemitism and the other observables. This test aims to check the amount of money households deposit in local banks, keeping constant the size of the local banks' activities. In columns (7)-(8) of Table 3, we find that a one-standard-deviation increase in antisemitism reduces the county-level ratio of deposits over the sum of local bank assets by 1.5 percentage points, which is $2 \%$ of the average ratio of deposits over assets across counties (76\%). This result is consistent with the notion that households in counties with higher historical antisemitism tend to use bank services less than other households.

For robustness purposes, in Table A.3 of the Online Appendix, we replicate the results described above in the PHF sample of German households surveyed in 2010. Historical antisemitism is unrelated to the likelihood that households save a part of their monthly income regularly, and it is unrelated to the likelihood that the household is a homeowner. Instead, higher antisemitism is associated with a lower likelihood of holding a mortgage, even after controlling for wealth and for the elicited risk tolerance, financial literacy, and religiosity of the household head. In addition, we find historical antisemitism is unrelated to outcomes that do not require accessing financial services (see columns (6)-(11)). In column (12) of Table A.3 of the Online Appendix, we also find suggestive evidence that households in counties with higher historical antisemitism keep a higher fraction of their wealth in cash form, although this effect is barely statistically significant. Overall, the PHF data also provide results consistent with the notion that present-day households in counties with higher historical antisemitism access financial services less than other households.

\section{The Deep Roots of Historical Antisemitism}

Our measure of historical antisemitism during the Nazi period might raise concerns it captures spatial variation in economic conditions in the Inter War period, which might have persisted for decades. To further disentangle the hypothesis that historical antisemitism relates to present-day financial decisions from other explanations related to localized economic shocks during the Nazi period, we build on the fact that the spatial variation in historical antisemitism within Germany has persisted for centuries since the Middle Ages, and especially since the Black Death of 1349 (Voigtlaender and Voth, 2012). The Black Death was arguably the worst pandemic in human history, and up to one half of the European population at the time may have died. Unsubstantiated theories on the origins of 
the pandemic diffused all over Europe. Accusations against Jews were common and led to persecution, especially in the German lands. Voigtlaender and Voth (2012) document that areas of Germany in which more pogroms against the local Jewish communities occurred during the Black Death of 1349 also displayed higher levels of antisemitism during the Nazi period.

In this section, we first test whether deep-rooted measures of historical antisemitism based on the violence against local Jewish communities during the Black Death of 1349 can predict the present-day stock market participation of German households in a similar manner as antisemitism during the Nazi period. Then, we exploit the deep roots of historical antisemitism and build on an historical natural experiment - the forced migrations of the first Ashkenazi Jewish communities through the German Lands after the First Crusade to design a strategy that exploits quasi-exogenous variation in the likelihood that German counties engaged in anti-Jewish violence in the past.

\section{A Medieval Pogroms, Historical Antisemitism, and Stock Market Participation}

We first replicate our baseline analysis by regressing the likelihood that households hold stocks today on the medieval-persecution proxy: the dummy equals 1 if a pogrom was documented in the county during the Black Death around 1349 (column (1) of Table 4). Pogroms in 1349 are associated with a 2-percentage-point-lower stock market participation by present-day households, which is $12.5 \%$ of the average participation rate. Thus, the association between our proxy for antisemitism in the Middle Ages and present-day stock market participation is statistically significant and economically large.

In columns (2)-(4) of Table 4, we assess the robustness of this result. First, we find that controlling for counties' longitude does not modify the result substantially. Then, we consider two subsamples of households when excluding areas in which one might believe historical antisemitism was either particularly high or particularly low in the past. In column (3), we exclude counties whose cities hosted at least one bishop seat. The rationale for this exclusion is that in counties with bishop seats, the ban on locals from engaging in moneylending might have been enforced more strictly than in other counties, and at the same time, a culture of distrust of moneylending might have been stronger. We find our baseline result is robust to this exclusion. In column (4), instead, we exclude cities that were part of the Hanseatic League. Hanseatic towns were more open to commerce and hence potentially more cultural tolerant than other counties, and at the same time, their trade activities required a large amount of financing compared to local economic activities in other counties. Even in this 
case, we find our baseline result is replicated.

In Table A.4 of the Online Appendix, we propose a large set of additional robustness tests and find that the negative associations between medieval antisemitism and current-day stock market participation are a robust feature of the data.

An important point to assess is whether our proxies for historical antisemitism are merely capturing Jewish settlements in the Middle Ages, because unobservables that favored the settlement of Jewish communities in the past could drive both historical antisemitism and present-day stockholdings. To address this point, we estimate specifications that include a dummy that equals 1 if the county was exposed to a Jewish community before the Black Death. Note the exposure to a Jewish community in the Middle Ages might be interpreted as a proxy for historical anti-Jewish sentiment by itself, as we discuss in section 3. This dummy might capture the potential for localized anti-Jewish sentiment that did not necessarily express itself in pogroms or major acts of violence against Jews. We compute the dummy at two horizons - exposure before 1300 and exposure just before the Black Death of 1349. In columns (5)-(6) of Table 4, we find the baseline associations between historical antisemitism and present-day stock market participation do not change in terms of magnitude or statistical significance once we add the dummy for exposure to Jewish communities before the Black Death. Exposure is negatively associated with present-day stock market participation, which suggests that either historical antisemitism that did not erupt in violence against Jews also helps explain stock market participation, or that counties with medieval exposure to Jews became less financially developed in the long run irrespective of antisemitism. In both cases, controlling directly for exposure to Jews does not change the baseline result that historical antisemitism is negatively related to present-day financial development.

Because medieval persecution and medieval exposure to Jewish communities aim to capture the deep roots of persecution, as opposed to unobservables related to the historical presence of Jews in a county, we would also expect that the baseline results do not change when using our measure of historical antisemitism during the Nazi period controlling for medieval exposure to Jewish communities. Indeed, in columns (7)-(8) of Table 4, we replicate our baseline results on the negative association between historical antisemitism and presentday stock market participation when controlling directly for the medieval exposure of counties to Jewish communities.

\section{$B$ Forced Migrations of Ashkenazi Jews and Three-Stage Least Squares}

Unobservable characteristics of German counties may have jointly determined Jewish persecution and long-run financial development. Ideally, we would have assigned anti-Jewish 
sentiment across similar German counties randomly before the Black Death of 1349, because the variation of historical antisemitism across counties has persisted since the Middle Ages.

To get close to such an experiment, we look at the forced migrations of Ashkenazi Jews out of the Rhine Valley after the $11^{\text {th }}$ century. We provide intuition for this strategy in Figure 3. In the top map of Figure 3, the darker is a county, the earlier is the first Jewish community documented in the county. Blank counties are those with missing data. The earliest Jewish presence in the German lands was found in the cities of Trier, along the Mosel, and Cologne, along the Rhine. Archaeologists date this presence to the ninth century. Research has found evidence of Jewish communities in the $10^{\text {th }}$ century along the entire Rhine Valley. ${ }^{11}$ The Jewish population in other areas of current Germany was sparse before the $11^{\text {th }}$ century (Engelman (1944)). At the onset of the Crusades, Christian knights traveling from England and France to the Holy Land persecuted Jewish communities. Several towns on the Rhine expelled Jews, causing a massive Jewish migration toward Eastern, Northern, and Southern Germany. Evidence of sizable Jewish communities dates back to the late $13^{\text {th }}$ and $14^{\text {th }}$ centuries in Munich (south) and Berlin (east) (Toch, 2012). ${ }^{12}$ The bottom maps of Figure 3 show the location of the cities of Trier, on the Mosel, and Emmerich, on the northern end of the German Rhine. The age of the first documented Jewish community in a county increases as one moves toward each of these cities.

We argue the distance of counties from the Rhine Valley determined the existence of Jewish communities at the time of medieval persecutions. In a first step, we use the distance of a county from the Rhine Valley to predict the probability that a Jewish community existed in the county before the Black Death. In a second step, we use the existence to predict the extent of Jewish persecution. The rationale is as follows: in counties with no Jewish communities before the Black Death, violence against Jews cannot have emerged, because no targets for such violence existed. In counties where early Jewish communities existed, the probability of an historical pogrom against the local Jews is strictly positive ex ante, because of the mere presence of Jews. ${ }^{13}$ In a third step, we use the persecution to predict present-day stock market participation.

Note this source of variation does not capture the different attitudes toward Jewish persecution across the counties that hosted Jewish communities, but only the variation in the likelihood of persecution between the counties that hosted a community and those that

\footnotetext{
${ }^{11}$ We refer to Toch (2012) as a comprehensive economic history of European Jews in the Middle Ages.

${ }^{12}$ Only in the $15^{\text {th }}$ century did Ashkenazi Jews merge with the communities of Khazar origin who had moved from the Black Sea to current Poland. See van Straten (2004) for archaeological evidence and Elhaik (2013) for genetic-based evidence.

${ }^{13}$ Of course, we will not necessarily observe a positive realization, that is, a pogrom in all of these counties ex post.
} 
did not. Both margins of variation in persecution are relevant to the effects we document.

For this test, we consider five measures of the distance of a county from the Rhine Valley. They are the Euclidean distances of a county's centroid from five large cities that lie at different longitudes on the Rhine and Mosel rivers, namely, Mainz, Worms, Speyer, Trier, and Emmerich, on the northern end of the German Rhine. The shortest distance is about $2 \mathrm{~km}$, whereas the greatest distance is $1100 \mathrm{~km}$. The alternative measures aim to capture alternative gradients of the distance from the Rhine Valley, ranging from the southwest/northeast gradient and the northwest/southeast gradient. Across all gradients, the likelihood that a Jewish community existed in the Middle Ages increases toward the Rhine Valley.

If we wanted to interpret this strategy as a causal test for the effect of Jewish persecution on present-day financial development, we should assume a demanding exclusion restriction. The distance of a county from the Rhine Valley should not affect current stock market participation through channels different from the county-level historical persecution against Jewish communities. Moreover, Jewish communities escaping from the Rhine Valley should have been equally likely to settle in any counties at the same distance from the Rhine Valley. Note if the latter condition did not hold, we would expect, if anything, that Jewish communities were more likely to settle in counties with higher demand for financial services; hence, the selection would bias our reduced-form coefficients downward.

We propose two tests to assess the extent to which this exclusion restriction may be economically plausible. First, in Panel A of Table 5, we estimate the reduced-form effect of the distances from the Rhine Valley on the ratio of households that own stocks when the distance, instead of historical antisemitism, enters as a regressor, and when both the distance and the VV P.C. enter jointly. All the coefficients refer to OLS regressions. In odd columns, all five distances are positively associated with the likelihood that households hold stocks. Once the VV P.C. enters the reduced-form specifications, the estimated autonomous associations between the distances and stockholdings drop in magnitude, whereas the estimated standard errors attached to coefficients barely change. This result suggests the distance from the Rhine Valley is unlikely to capture unobserved determinants of present-day stockholdings, which are not already captured by historical antisemitism.

Second, in Panel B of Table 5, we look at the effect of the distance on the likelihood that French households own stocks. If the distance from the Rhine captures anything peculiar to the spatial diffusion of development or wealth, we should observe an effect of the distance on the stockholdings by French households to the west of the Rhine. Instead, if distance captures Jewish persecution, we should find no effect of distance on the stockholdings of French 
households, because Jews did not escape to France, where Crusaders were already persecuting local Jewish communities. Across all our measures, we find no economically or statistically significant association between the distance from the Rhine and the stockholdings of French households.

To implement the three-stage strategy, we estimate the following linear system by OLS (see Becker and Woessmann (2009)):

$$
\begin{aligned}
& \text { Community } 1349_{i k}=\alpha+\beta \times \text { Log Distance Rhine } \text { Rik }+K_{i k}^{\prime} \times \delta+\epsilon_{i k} \\
& \text { Historical Antisemitism }_{i k}=\alpha+\beta \times{\text { Community } 1349_{i k}+K_{i k}^{\prime} \times \delta+\epsilon_{i k}}_{\text {Stockhold }_{i k}}=\alpha+\beta \times \text { Historical Antisemitism } \\
&
\end{aligned}
$$

where Community $1349_{i k}$ and Persecution $i k$ are the predicted values for county $k$ when estimating the system of three simultaneous equations.

Panel A of Table 6 reports the results for estimating the first stage of the system, that is, the association between each measure of distance from the Rhine Valley and the likelihood that a Jewish community existed in the county in 1349, the time of the Black Death. Panel $\mathrm{B}$ reports the results for estimating the second stage of the system, whereas Panel $\mathrm{C}$ refers to the third stage.

In Panel A, the farther a German county is from the Rhine, the less likely a Jewish community is to have existed there in 1349. A one-standard-deviation increase in any of the distance measures is associated with a 13- (Trier) to 23-percentage-point (Worms) drop in the likelihood a community existed in 1349. In Panel B, the instrumented likelihood of a Jewish community in a county in 1349 increases the VV P.C. of historical Jewish persecution across all measures of distance. In Panel C, consistent with the baseline results, an increase in the instrumented persecution of Jews significantly reduces stock market participation when using any of the measures of distance from the Rhine Valley.

In Table 6, the measure of historical antisemitism we use is the Voigtlaender-Voth principal component of Jewish persecution during the 1920s and 1930s, because this component is the baseline measure we proposed throughout the analysis. In Table A.5 of the Online Appendix, we run the same three-stage least-squares analysis using the measure of medieval antisemitism in the second stage, and we show all the results are similar. 


\section{Channels Mediating the Effect of Historical Antisemitism on Financial Decisions}

Several supply- and demand-side channels could explain the relationship between historical antisemitism, Jewish specialization in finance, and present-day financial development. After describing briefly the channels we consider, we proceed to assess their potential role in explaining our results.

On the supply side, historical persecution of local Jewish communities paired with the Jewish economic specialization in the financial sector could have represented a negative shock to the local availability and/or quality of local financial services. This negative shock could reflect on the quality and efficiency of present-day local financial services, as long as the segmentation across local financial markets has not completely disappeared over time. The negative shock could have persisted if, for instance, lower-quality local financial institutions replaced Jewish-run financial institutions in areas in which the Jewish population was persecuted more in the past. ${ }^{14}$ In this section, we use two sources of data to assess the possibility that this channel explains our results, namely, data on the efficiency of the present-day German banking sector at the county level from the German Council of Economic Experts and data on the foundation dates of German Volksbanken and Raiffeisenbanken from the Hoppenstedt database, which allows us to construct the spatial pattern of diffusion of credit unions across the German lands in the second half of the $19^{\text {th }}$ century.

On the demand side, any potential channel that might partially explain our findings requires that historical antisemitism reduces households' present-day demand for financial services at the local level. Voigtlaender and Voth (2015) show that present-day antisemitic beliefs across Germany are positively correlated with historical antisemitism. This fact suggests three potential demand-side channels for our results. First, historical antisemitism might capture present-day households' "backwardness," that is, a set of cultural cues and beliefs that promote distrust of the unfamiliar, including but not limited to stocks and financial services. Second, present-day households that are antisemitic may still associate financial services with Jews based on the historical economic specialization of Jews in finance, and thus invest less in stocks and demand fewer financial services. Third, the combination of historical antisemitism with the Jewish specialization in financial services in the past might have produced a local cultural norm of distrust in finance. This norm might have persisted

\footnotetext{
${ }^{14}$ Note that this potential channel would be the opposite of the channel documented by Pascali (2016). In Pascali (2016), the areas of Southern Italy from which Jews were expelled had seen the development of competing Christian financial institutions that explain the higher quality of the banking sector in those areas today, compared to areas that had never hosted Jews.
} 
over time alongside antisemitism, and hence might still affect the financial decision-making of present-day households-even those current-day households that are not antisemitic. In this section, we use two sources of data to address the possibility that one or more of these channels help explain our results: (i) confidential data on present-day antisemitism as well as other forms of xenophobia and racist beliefs from ALLBUS, which we were able to merge with the confidential information in SOEP for the first time; and (ii) a survey of present-day German households in which we elicited households' trust in banks and the stock market, in addition to several other sets of beliefs and attitudes.

\section{A Supply-Side Channels}

To assess the possibility that historical antisemitism paired with the Jewish specialization in finance is associated with the quality of the present-day supply side of financial services across German counties, we start with testing whether historical antisemitism correlates negatively with the present-day efficiency of the local banking sector.

To this aim, we obtained data on the efficiency of the present-day German banking sector at the county level from the German Council of Economic Experts. The data include a wealth of measures of efficiency of present-day local banking systems, each of which captures a different aspect of efficiency and competitiveness. The data cover measures of (i) cost efficiency, (ii) price efficiency, and (iii) Lerner indices, defined as the difference between average revenues and marginal cost of the bank scaled by average revenues. Higher values of the Lerner index indicate higher market power for the banks in the county, because in a perfectly competitive market, average revenues equal marginal cost. Koetter (2013) describes the calculation of these measures in detail. For each measure, the data include a bank-level fixed-effect-panel stochastic frontier version (FEM), a latent-class stochastic frontier model version (LCM), and a cross-sectional stochastic frontier version (CSSF).

Table 7 reports the results of this analysis. We run a set of county-level regressions, whose right-hand side includes the same county-level controls as in equation (1). The measure of historical antisemitism is the VV P.C. of Jewish persecution. In each column of Table 7, the outcome variable is the measure of efficiency of the local banking system indicated at the top. Across the board, we fail to detect any systematic association between historical antisemitism and the present-day efficiency of the local banking sector, irrespective of the measure of efficiency we consider. The coefficients we estimate are neither economically nor statistically different from zero, and the sign of the point estimates changes across specifications. We interpret these results as direct evidence that historical antisemitism is not related to the present-day efficiency of the the local German banking sector. 
These non-results are inconsistent with a long-run effect of Jewish persecution on the present-day supply of finance, although they might be consistent with a decrease in the supply side of finance in the past, alongside the decrease in the demand for finance. Whereas the county-level segmentation of financial services may have faded over time due to financial integration of German regions, the demand for financial services may not have changed. In particular, since 1843, credit unions (Volks- and Raiffeisenbanken) have diffused across Germany. They did and still do specialize in financing local businesses and collecting households' savings. If credit unions diffused early into more antisemitic areas, current households in those areas might be less aware of the opportunity to invest in stocks.

To assess this hypothesis, we collected data on the foundation dates of credit unions across German counties from the proprietary registry of the Hoppenstedt Firmendatenbank. ${ }^{15}$ Panel (a) of Figure A.5 of the Online Appendix shows the diffusion path of credit unions across Germany. In Panel (b) of Figure A.5 of the Online Appendix, we plot the year the first credit union is documented in a county against the ratio of deported Jews over the 1933 Jewish population at the county level. The two dimensions are not negatively correlated, so credit unions did not diffuse earlier in the more antisemitic counties.

A third potential supply-side channel concerns the skill structure of counties. Persecution may have reduced local financial services because a large share of finance workers were Jewish. If the depletion of human capital needed to run financial institutions drove our baseline effect, the effect should be larger in counties with a higher ratio of Jewish workers in finance in the past. We find no systematic association between the ratio of Jews in finance as of 1882 or 1933 and present-day stockholdings (see Panel (a) and Panel (b) of Figure A.6 of the Online Appendix). In untabulated results, we estimate our baseline specification using the present-day number of bank branches per capita at the county level as our dependent variable on the measures of historical antisemitism, and we find these two dimensions are also unrelated.

Note that, unlike the case of Italy studied by Pascali (2016), institutions the Church supported to compete with the Jewish monopoly in banking did not diffuse in Germany. In Pascali (2016), Christian financial institutions founded in areas with ethnic tension against Jews improved the strength of the financial sector in areas with higher historical ethnic tensions.

\footnotetext{
${ }^{15}$ The registry reconstructs the chains of mergers and acquisitions over the decades for currently existing German banks. They collect the foundation date, the type, and other characteristics of any entity involved in these chains as far back as any information is retraceable.
} 


\section{$B$ Demand-Side Channels}

Moving on to assessing potential demand-side channels, we first study the relationship between historical antisemitism, present-day antisemitism, and present-day stock market participation. Voigtlaender and Voth (2013) show that county-level historical antisemitism explains the spatial variation in present-day antisemitism. Based on this result, county-level measures of present-day antisemitism should be negatively associated with stock market participation. Note that present-day antisemitism could even be a demand-side channel that in part explains our results. Present-day households that are antisemitic may still associate financial services with Jews, and thus invest less in stocks and demand fewer financial services. Instead, if variation in historical antisemitism drives our results, and if historical antisemitism is not measured with substantial error, we should not detect a negative association between present-day antisemitism and stock market participation once we control for both historical antisemitism and present-day antisemitism in the same specification.

To discriminate between these alternative channels, we combined for the first time two proprietary individual-level geolocated German data sources, namely, the ALLBUS data on present-day social beliefs and the SOEP. From the ALLBUS data, we construct a measure of present-day antisemitism as the county-level average of individual responses regarding attitudes toward Jews, which were elicited in 1996 and 2006. As a main measure of current antisemitism, we use the reciprocal of the answer to question 307, which reads as follows: "Jewish people living in Germany should have the same rights as Germans in every respect." The answer scale ranges from 1 (Completely disagree) to 7 (Completely agree). ${ }^{16}$

Table 8 provides evidence that supports our conjectures. Column (1) regresses the dummy for stockholdings only on the measure of present-day antisemitism. Present-day antisemitism predicts present-day stock market participation negatively, as we would expect based on the long-run persistence of antisemitism at the local level, which Voigtlaender and Voth (2013) document. Column (2) regresses the dummy for stockholdings on the measure of present-day antisemitism as well as the set of historical controls in our baseline analysis. Again, we find a negative, statistically significant association just as in column (1). In column (3), we add our measure of historical antisemitism (VV P.C.) to the specification of column (2), and we see that adding this variable makes the association between presentday antisemitism and stockholdings insignificant, both economically and statistically. At the same time, the size and statistical significance of our baseline effect do not change

\footnotetext{
${ }^{16}$ In untabulated results, we find that all the results are virtually identical when we use alternative questions related to current antisemitism and xenophobia.
} 
once present-day antisemitism enters the set of controls. Finally, column (4) reports the specification with the full set of controls from Table 2 and confirms our findings.

A related potential demand-side channel is present-day households' "backwardness," that is, a set of cultural cues and beliefs that promote distrust of the unfamiliar, including stocks and financial services. Present-day antisemitism might be a weak proxy for backwardness, which would be why we do not detect an association with stock market participation once we control for historical antisemitism. To test whether "backwardness" might explain our results, we construct a measure for present-day xenophobia at the county level using the ALLBUS data, similar to the way we constructed the measure of present-day antisemitism described above. The measure of present-day xenophobia is the reciprocal of the answer to question 306, which reads as follows: "Turkish people living in Germany should have the same rights as Germans in every respect." The answer scale ranges from 1 (Completely disagree) to 7 (Completely agree). We also use answers for the same question referring to other minorities, namely, Italians and asylum seekers. In columns (5)-(10) of Table 8, we find that present-day xenophobia does not explain stock market participation, whether we control directly for historical antisemitism or not, whereas the size and statistical significance of our baseline effect are unchanged.

Motivated by Gennaioli et al. (2015), we move on to test directly whether a persistent cultural norm of distrust in finance, transmitted across generations, might contribute to explaining our results. Past households in counties where strong negative stereotypes against the Jews had developed might have also developed a negative stereotype toward what the Jews represented at the time, namely, the financial sector.

We do not observe distrust of financial institutions for the households in the SOEP sample, and hence, we run our own survey on a sample of 1,000 German households, asking them the extent to which they trust the stock market, commercial banks (Privatbanken), and local banks (Sparkassen and Genossenschaftsbanken). The company ClickWorker administered the survey on a stratified sample of the German population that sign up to the platform to perform tasks and surveys for pay. The respondents only know they are part of a survey, and they ignore the identity or scopes of the researchers. This protocol is crucial to avoid demand effects invalidating the procedure. We also ask for demographics and the zip code in which respondents reside, which we map into counties.

We adapted the questions developed for the United States in the Kellogg-Booth Index of Financial Trust (Sapienza and Zingales (2012)). After providing their demographics, the respondents answered a set of four questions asking the extent to which they trust others (generalized trust), the stock market, commercial banks, and local banks, on a scale from 
1 (do not trust at all) to 7 (trust completely). We also elicited households' willingness to take risks in general and in financial decisions, on a similar scale from 1 to 7 . Finally, the respondents reported whether they owned stocks and whether they had a primary banking relationship with a commercial bank or with a local bank. The final sample on which we can run the analysis is about one half the original 1,000 households. This drop in the sample size is due to the loss of respondents in counties for which we have no historical persecution data. Also, our final sample is distributed across 57 counties, because we don't have respondents for all German counties in the survey, and we only consider counties for which we have at least five respondents, to guarantee the representativeness of the answers. ${ }^{17}$

To make the results directly comparable to the baseline analysis, we transform the trust measures into dummy variables that equal 1 if the measure is larger than or equal to 5 , and zero otherwise, and we estimate probit specifications whose outcomes are the trust in each of the financial institutions. ${ }^{18}$ Table A.7 of the Online Appendix reports the summary statistics and the correlational structure across these trust measures. Interestingly, the correlations across the financial trust measures, and with generalized trust, are positive but not high. A "pecking-order" of trust exists in financial institutions: on average, $41 \%$ of respondents trust local banks, $17 \%$ trust commercial banks, and only $13 \%$ trust the stock market. The average generalized trust is $39 \%$, and its correlation with the measures of financial trust varies from $9 \%$ to $11 \%$ across measures. Risk tolerance is correlated with the trust in the stock market (38\%), but not with the trust in local banks (2\%), which suggests controlling for the respondent's risk tolerance in the analysis is important.

In Panel A of Table 9, we regress the trust in the stock market on VV P.C. (columns (1)(2)), after controlling for generalized trust, risk tolerance, and demographics at the individual level. A one-standard-deviation increase in historical antisemitism is associated with a 4percentage-point drop in the respondents' trust in the stock market. Columns (3)-(4) of Table 9 report a similar specification whose outcome is the dummy for whether respondents trust commercial banks, and columns (5)-(6) of Table 9, for whether respondents trust local banks. We do not detect an association between Jewish persecution and the trust in commercial banks, but we find that a one-standard-deviation increase in persecution is associated with an 8-percentage-point drop in the trust in local banks.

Panel B of Table 9 shows the trust measures we elicit are positively associated with the trusted outcomes, even when controlling for generalized trust, risk tolerance, and respondents' demographics.

\footnotetext{
${ }^{17}$ The results are similar if we change this threshold.

${ }^{18}$ All the results are qualitatively similar if we instead use the original categorical variables and estimate multinomial logit specifications.
} 
Finally, in Panel C of Table 9, we replicate our baseline result - the negative association between historical antisemitism and present-day stockholdings - also in the sample of households that respond to our survey. Despite the substantially smaller size of the survey sample, we do find that a one-standard-deviation-higher measure of historical antisemitism is associated with about a -1.5-percentage-point likelihood that households hold stocks.

\section{Discussion}

Overall, the tests in this section do not allow us to assess definitively the extent to which each potential channel migth help explain our results. At the same time, we do not find supporting evidence for any of the supply- and demand-side channels we consider, with the exception of a cultural norm of distrust in finance, transmitted locally across generations and still influencing German households' financial decisions.

Theoretically, localized norms can persist through two forces - vertical transmission from parents to offspring within a household and horizontal transmission through the homogenization of norms within communities, to which individual members belong (e.g., see Bisin and Verdier (2000) and Bisin and Verdier (2001)). Recent research has provided empirical support for these theoretical mechanisms of transmission of cultural norms (e.g., see Dohmen, Falk, Huffman, and Sunde (2012)). A theoretical framework for our results should also explain under which conditions the initial norm of antisemitism created an independent norm of distrust in finance. Several potential theoretical channels exist, which we discuss in more detail below. Our findings are most consistent with a norm of distrust in finance that developed in the Middle Ages and transmitted across generations independent of antisemitism.

First, antisemitism in the Middle Ages might have persisted at the local level and resulted in higher antisemitism during the Nazi period. Because of the strong rhetoric against Jews as manipulators of the stock market during the Nazi regime, to which all Germans were exposed via mass media such as the radio (Adena et al., 2015), a norm of distrust in finance might have started at that point in time and then transmitted over the last few decades independently from antisemitism. This channel is not fully consistent with the fact that we find a negative effect of medieval and Nazi-period antisemitism on several financial outcomes above and beyond stock market participation, such as the willingness to take on mortgages to finance homeownership as well as lower retail deposits at the local level. Jews were not associated with the banking system during the Nazi period, but they were in the previous centuries.

A second explanation is that distrust in finance pre-dates historical antisemitism and 
in fact caused pogroms against Jews in the Middle Ages. Localized antisemitism and distrust in finance then might have persisted for centuries at the local level. We cannot test directly whether distrust in finance caused ethnic tensions between Christians and Jews, or whether ethnic tensions paired with ethnic specialization produced a norm of distrust in finance over time, because we cannot observe households' attitudes toward finance in the Middle Ages. But if the cross-sectional variation of distrust in finance existed prior to antisemitism, it would have been produced by religious norms, and hence should have reflected the extent of religiosity across German counties in the distant past and possibly at the present day. ${ }^{19}$ We use the World Value Survey to construct a direct measure of the importance of religion at the local level for present-day households, irrespective of their religious denomination. Region-wide religiosity is negatively related to present-day stock market participation, but controlling for it does not change our results.

Third, persecution against Jews in the Middle Ages might have also included a norm of distrust in moneylending and financial activities at its very origin, in the Middle Ages, and the two norms of antisemitism and distrust in finance might have transmitted in parallel over time. Antisemitism faded because of the vigorous interventions by the German administration to eradicate antisemitic beliefs from Germany after WWII, especially in schools, whereas no systematic interventions have addressed a potential norm of distrust in finance. This latter theoretical framework for the transmission of two parallel norms seems the only one consistent with all our evidence, but ultimately we cannot provide direct tests to disentangle the three theoretical explanations in our setting.

\section{Conclusions}

Historical ethnic tensions paired with ethnic specialization produce long-run discrimination against the economic activities in which minorities specialized. We show this combination has substantial effects on long-run economic decision-making and helps us understand the persistent spatial variation in financial development. Households in German counties where historical antisemitism was higher in the Middle Ages and the Nazi period access financial services less than other households. They are less likely to hold stocks, they have fewer mortgages, but not lower homeownership, and they put less savings into bank accounts, but are as likely as other households to save. We find suggestive evidence that households in counties with higher historical antisemitism are more likely to keep their money in cash form.

We assess a set of channels that might explain how ethnic tensions and ethnic specialization can affect economic outcomes in the long run. A set of supply-side explanations

\footnotetext{
${ }^{19}$ We thank Paola Sapienza, our NBER discussant, for proposing this argument.
} 
do not appear to be able to fully explain our findings. On the demand side, our results are consistent with a lingering discrimination against financial services by households in counties in which historical antisemitism was higher.

Future research should study which policy interventions might moderate the transmission of norms that affect the economic decision-making process of households in the long run. For instance, can financial education dissipate a deep-rooted norm of discrimination against financial services, by making households aware of the costs of not accessing finance? Or do households decide not to invest despite knowing the negative effects of their actions on the long-run accumulation of financial wealth? Answering these questions is crucial to designing policies that might increase financial development in the long run, and to inform governments on which costly place-based policies they implement might be ineffective simply because they do not affect the ultimate determinants of local underdevelopment.

Our results contribute to the interdisciplinary debate on inter-ethnic tensions, hatred beliefs, and their long-term consequences on societies. Because of the historically high equity premium and the reliance of firms on equity capital, hatred against Jews in the past reduces the long-term wealth not only of the persecuted, but of the persecutors as well. 


\section{References}

Acemoglu, D., D. Cantoni, S. Johnson, and J. Robinson (2011). The consequences of radical reform: The French Revolution. American Economic Review 101(7), 3286-3307.

Acemoglu, D., T. Hassan, and J. Robinson (2011). Social structure and development: A legacy of the holocaust in Russia. Quarterly Journal of Economics 126(2), 895-946.

Adena, M., R. Enikolopov, M. Petrova, V. Santarosa, and E. Zhuravskaya (2015). Radio and the rise of the Nazis in prewar Germany. Quarterly Journal of Economics 130(4), $1885-1939$.

Akbulut-Yuksel, M. and M. Yuksel (2015). The longer-term direct and external effects of Jewish expulsions in Nazi Germany. American Economic Journal: Economic Policy 7(3), $58-85$.

Algan, Y. and P. Cahuc (2010). Inherited trust and growth. American Economic Review $100(5), 2060-2092$.

Alicke, K.-D. (2008). Lexikon der Jüdischen Gemeinden im deutschen Sprachraum. Gütersloh, Germany: Gütersloher Verlagshaus.

Anderson, R., N. Johnson, and M. Koyama (2017). Jewish persecution and weather shocks: 1100-1800. Economic Journal 127(602), 924-958.

Banfield, E. (1958). The Moral Basis of a Backward Society. Glencoe, IL: Free Press.

Barclay, J. (1996). Jews in the Mediterranean Diaspora: From Alexander to Trajan (323 $B C E-117 C E)$. Berkeley, CA: University of California Press.

Becker, S., F. Cinnirella, E. Hornung, and L. Woessmann (2014). iPEHD - The Prussian Ifo economic history database. Historical Methods 47(2), 57-66.

Becker, S. and L. Pascali (2017). Religion, division of labor and conflict: Anti-semitism in german regions over 600 years. Working Paper.

Becker, S. and L. Woessmann (2009). Was Weber wrong? A human capital theory of Protestant economic history. Quarterly Journal of Economics 124(2), 531-596.

Betermier, S., T. Jansson, C. Parlour, and J. Walden (2012). Hedging labor income risk. Journal of Financial Economics 105(3), 622-639.

Bisin, A. and T. Verdier (2000). Beyond the melting pot: Cultural transmission, marriage, and the evolution of ethnic and religious traits. Quarterly Journal of Economics 115(3), 955-988.

Bisin, A. and T. Verdier (2001). The economics of cultural transmission and the dynamics of preferences. Journal of Economic Theory 97(2), 298-319.

Bonacich, E. (1972). A theory of ethnic antagonism: The split labor market. American Sociological Review 37(5), 547-559.

Bonacich, E. (1973). A theory of middleman minorities. American Sociological Review 38(5), 583-594.

Botticini, M. and Z. Eckstein (2012). The Chosen Few: How Education Shaped Jewish History, 70-1492. The Princeton Economic History of the Western World. Princeton, NJ: Princeton University Press.

D’Acunto, F. (2016). From financial history to history \& finance. Working Paper. 
D’Acunto, F. (2017). Basic education and persistent regional inequalities. Working Paper.

de Bromhead, A., B. Eichengreen, and K. O'Rourke (2013). Political extremism in the 1920s and 1930s: Do the German lessons generalize? Journal of Economic History 73 (2), $371-406$.

Dohmen, T., A. Falk, D. Huffman, and U. Sunde (2012). The intergenerational transmission of risk and trust attitudes. Review of Economic Studies 79(2), 645-677.

Elhaik, E. (2013). The missing link of Jewish European ancestry: Contrasting the Rhineland and the Khazarian hypotheses. Genome Biology and Evolution 5(1), 61-74.

Engelman, U. Z. (1944). The Rise of the Jew in the Western World: A Social and Economic History of the Jewish People of Europe. New York, NY: Arno Press.

Falter, J. and D. Hänisch (1988). Wahl- und Sozialdaten der Kreise und Gemeinden des Deutschen Reiches 1920-1933. Köln, Germany: GESIS Datenarchiv.

Flannery, E. (1985). The Anguish of the Jews: Twenty-Three Centuries of Antisemitism. New York, NY: Paulist Press.

Fritsch, T. (1892). Statistik des Judenthums. Number 10 in Kleine Aufkl arungs-Schriften. Leipzig, Germany.

Gennaioli, N., R. La Porta, F. Lopez-de Silanes, and A. Shleifer (2013). Human capital and regional development. Quarterly Journal of Economics 128(1), 105-164.

Gennaioli, N., A. Shleifer, and R. Vishny (2015). Money doctors. Journal of Finance 70(1), 91-114.

Georgarakos, D., A. Lojschova, and M. Ward-Warmedinger (2010). Mortgage indebtedness and household financial distress. ECB Working Paper Series No. 1156.

Giannetti, M. and T. Wang (2016). Corporate scandals and stock market participation. Journal of Finance 71(6), 2591-2636.

Glagau, O. (1876). Der Börsen- und Gründungs-Schwindel in Berlin. Verlag v. Paul Frohberg.

Gormley, T., H. Liu, and G. Zhou (2010). Limited participation and consumption-saving puzzles: A simple explanation and the role of insurance. Journal of Financial Economics 96(2), 331-344.

Grosfeld, I., A. Rodnyansky, and E. Zhuravskaya (2013). Persistent anti-market culture: A legacy of the Pale of Settlement after the Holocaust. American Economic Journal: Economic Policy 5(3), 189-226.

Grosfeld, I., S. Sakalli, and E. Zhuravskaya (2017). Middlemen minorities and ethnic violence: Anti-Jewish pogroms in the Russian Empire. Working paper.

Gross, N. (Ed.) (1975). Economic History of the Jews. Library of Jewish Knowledge. Jerusalem: Keter Publishing House Jerusalem.

Guiso, L. and T. Jappelli (2005). Awareness and Stock Market Participation. Review of Finance 9(4), 537-567.

Guiso, L., T. Jappelli, and D. Terlizzese (1996). Income risk, borrowing constraints, and portfolio choice. American Economic Review 86(1), 158-172. 
Guiso, L., P. Sapienza, and L. Zingales (2004a). Does local financial development matter? Quarterly Journal of Economics 119(3), 929-969.

Guiso, L., P. Sapienza, and L. Zingales (2004b). The role of social capital in financial development. American Economic Review 94(3), 526-556.

Guiso, L., P. Sapienza, and L. Zingales (2009). Trusting the stock market. Journal of Finance 63(6), 2557-2600.

Hitler, A. (1939). Mein Kampf - Murphy Translation, Vol. I, chapter XI: Race and People. Hurst and Blackett.

Hong, H., J. Kubic, and J. Stein (2004). Social interaction and stock market participation. Journal of Finance 59(1), 137-163.

Horowitz, D. (1985). Ethnic Groups in Conflict. Berkeley, CA: University of California Press.

Jha, S. (2013). Trade, institutions, and ethnic tolerance: Evidence from South Asia. American Political Science Review 107(4), 806-832.

Jha, S. (2014). 'Unfinished business': Historic complementarities, political competition and ethnic violence in Gujarat. Journal of Economic Behavior and Organization 104, 18-36.

King, G., O. Rosen, M. Tanner, and A. Wagner (2008). Ordinary economic voting behavior in the extraordinary election of Adolf Hitler. Journal of Economic History 68(4), 951-996.

Koetter, M. (2013). Market structure and competition in German banking. Working Paper.

Köhler, I. (2005). Die "Ariesirung" der Privatbanken im Dritten Reich: Verdrängung, Ausschaltung und die Frage der Wiedergutmachung. Munich, Germany: Beck.

Malmendier, U. and S. Nagel (2011). Depression babies: do macroeconomic experiences affect risk-taking? Quarterly Journal of Economics 126(1), 373-416.

Nunn, N. (2014). Handbook of Economic Growth, Volume 2, Chapter Historical Development, pp. 347-402. Amsterdam: Elsevier North Holland.

Pascali, L. (2016). Banks and development: Jewish communities in the Italian Renaissance and current economic performance. Review of Economics and Statistics 98(1), 140-158.

Paxson, C. (1990). Borrowing constraints and portfolio choice. Quarterly Journal of Economics 105(2), 535-543.

Penslar, D. (2001). Shylock's Children: Economics and Jewish Identity in Modern Europe. Berkeley, CA: University of California Press.

Perry, M. and T. Schweitzer (2002). Antisemitism: Myth and Hate from Antiquity to the Present. New York, NY: Palgrave Macmillan.

Pierce, L. and J. Snyder (2017). The historical slave trade and firm access to finance in Africa. Review of Financial Studies.

Poliakov, L. (1975). The History of Anti-Semitism, Volume 3. London, UK: Routledge \& Kegan Paul Publishers. trans. Miriam Kochan.

Putnam, R. (1993). Making Democracy Work: Civic Traditions in Modern Italy. Princeton, NJ: Princeton University Press. 
Ramankutty, N., J. Foley, J. Norman, and K. McSweeney (2002). The global distribution of cultivable lands: Current patterns and sensitivity to possible climate change. Global Ecology and Biogeography 11(5), 377-392.

Reuveni, G. and S. Wobick-Segev (Eds.) (2011). The Economy in Jewish History: New Perspectives on the Interrelationship between Ethnicity and Economic Life. New York, NY: Berghahn Books.

Roth, C. (1938). The Jewish Contribution to Civilization. London, UK: Macmillan and Co.

Roth, C. (1960). The Jews: Their History, Culture, and Religion (3rd ed.)., Chapter The European Age in Jewish History, pp. 216-286. New York, NY: Harper \& Brothers.

Samuelson, P. (1969). Lifetime portfolio selection by dynamic stochastic programming. Review of Economics and Statistics 51(3), 239-246.

Sapienza, P. and L. Zingales (2012). A trust crisis. International Review of Finance 12(2), $123-131$.

Spolaore, E. and R. Wacziarg (2013). How deep are the roots of economic development? Journal of Economic Literature 51(2), 325-369.

Toch, M. (2012). The Economic History of European Jews: Late Antiquity and Early Middle Ages. Leiden: Brill.

van Rooij, M., A. Lusardi, and R. Alessie (2011). Financial literacy and stock market participation. Journal of Financial Economics 101(2), 449-472.

van Straten, J. (2004). Jewish migrations from Germany to Poland: the Rheinland hypothesis revisited. The Mankind Quarterly 44(3-4), 367-384.

Voigtlaender, N. and H. Voth (2012). Persecution perpetuated: The medieval origins of antiSemitic violence in Nazi Germany. Quarterly Journal of Economics 127(3), 1339-1392.

Voigtlaender, N. and H. Voth (2013). Married to intolerance: Attitudes towards intermarriage in Germany, 1900-2006. American Economic Review Papers and Proceedings 103(3), 79-85.

Voigtlaender, N. and H. Voth (2015). Nazi indoctrination and anti-Semitic beliefs in Germany. Proceedings of the National Academy of Sciences 112(26), 7931-7936.

Waldinger, F. (2010). Quality matters: The expulsion of professors and the consequences for PhD students' outcomes in Nazi Germany. Journal of Political Economy 118(4), 787-831. 
Figure 2: Data Properties: Historical Antisemitism and Stock Market Participation

(a) Ratio Deported Jews Nazi Period

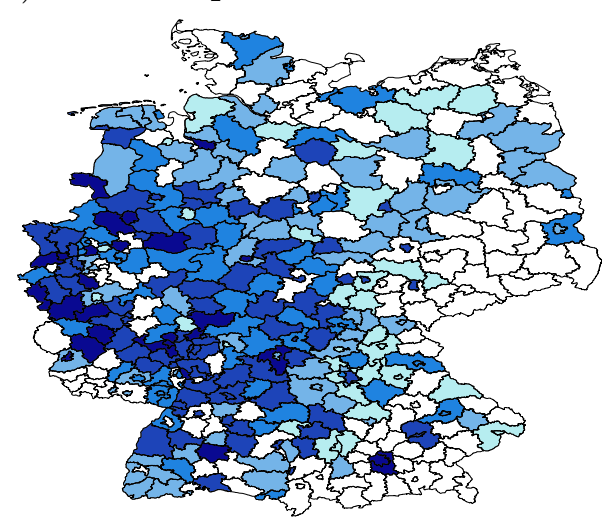

(c) Ratio Deported Jews Nazi Period

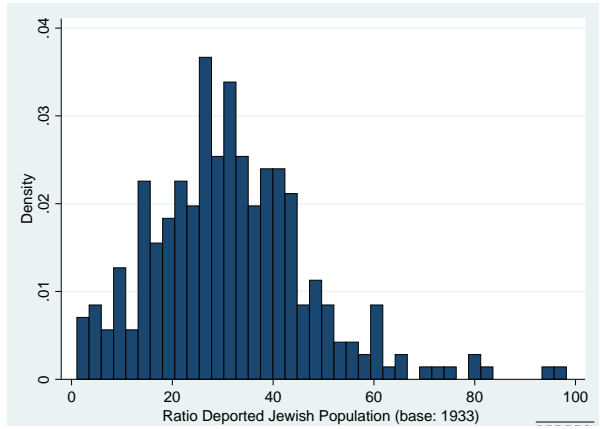

(e) Ratio Deported Jews Nazi Period

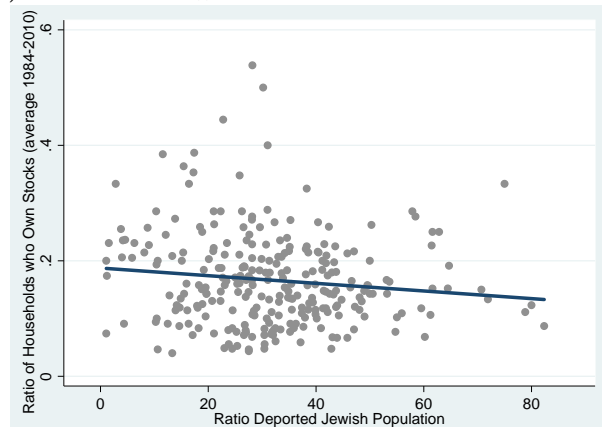

(b) Stock Market Participation

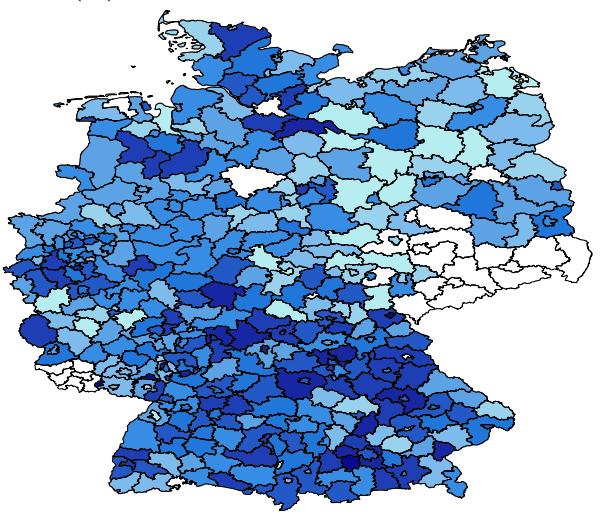

(d) Stock Market Participation Density

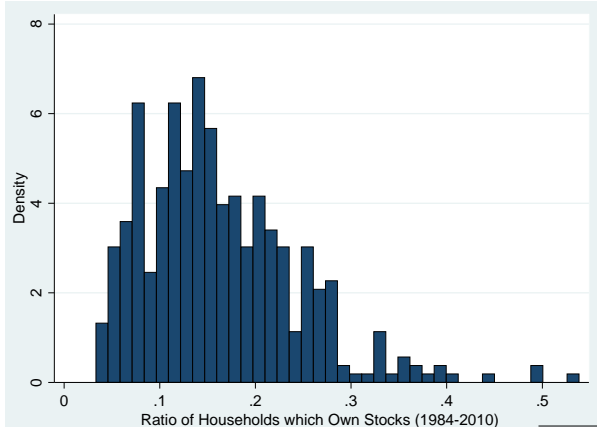

(f) Pogroms and Participation

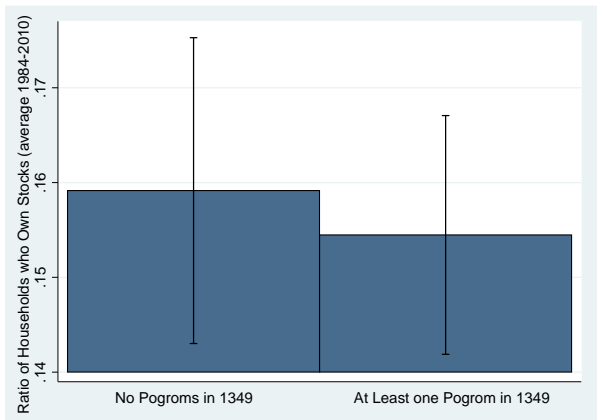

In Panels (a) and (b), the darker a county is, the higher the value of the depicted variable. Blank counties are those for which the data are not available. Panel (a) plots the ratio of Jews deported during the Nazi period over the Jewish population in the county as of 1933. Panel (b) plots the average yearly ratio of households who have invested in stocks from 1984 to 2011. Panels (c) and (d) plot the sample distributions of the same measures as above. Panel (e) depicts the unconditional correlation between stock market participation and the ratio of Jews deported during the Nazi period over the Jewish population in the county as of 1933. Panel (f) shows the mean stock market participation in counties that experienced and did not experience a pogrom in 1349 . 
Figure 3: Settlement of Jewish Communities and Distance from the Rhine Valley

(a) Year when the first Jewish community was documented

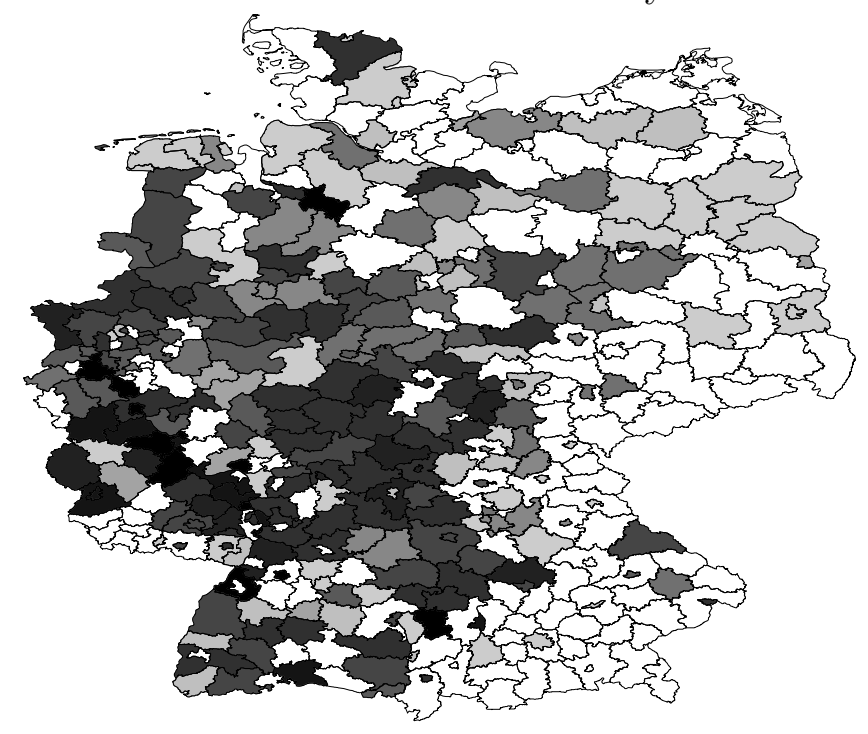

(b) Counties at same distance from Trier

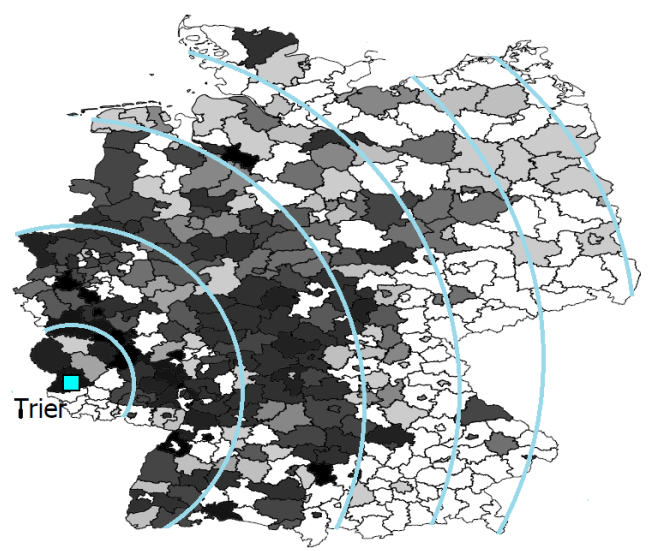

(c) Counties at same distance from Emmerich

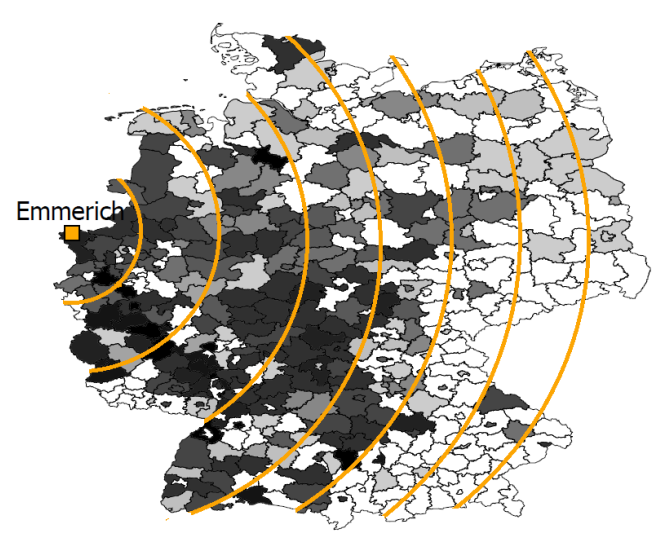

The maps document the foundation dates of Jewish communities at the county level. The darker a county is, the earlier a Jewish community was documented in that county. Blank counties are those for which the data are not available. The bottom maps show the location of the cities of Trier, on the Mosel, and Emmerich, on the northern end of the river Rhine in Germany. The isodistance curves centered around those two cities emphasize which counties are at the same distance from Trier or Emmerich. 


\section{Table 1: Summary Statistics}

This table reports summary statistics for measures of historical antisemitism in Germany, and for the characteristics of households and counties where households live. Each observation is a German household interviewed by SOEP any time between 1984 and 2011. For each variable, the table reports the number of observations for which the variable is observed, its mean, standard deviation, minimal, and maximal values. The table reports statistics for households for which we observe the county of residence. We exclude repeated observations. Historical Antisemitism (VV P.C.) is the principal component of Voigtlaender and Voth (2012) of their different measures of Jewish persecution in the 1920s-1930s, Medieval Antisemitism (Pogrom 1349) is a dummy variable that equals 1 if a pogrom against Jews occurred during the Black Death, and Exposure to Jews pre-1300 is a dummy variable that equals 1 if a county hosted a Jewish community before 1300.

\begin{tabular}{|c|c|c|c|c|c|}
\hline & $\begin{array}{c}\text { Obs. } \\
(1)\end{array}$ & $\begin{array}{c}\text { Mean } \\
(2)\end{array}$ & $\begin{array}{l}\text { Std } \\
(3)\end{array}$ & $\begin{array}{c}\text { Min } \\
(4)\end{array}$ & $\begin{array}{c}\operatorname{Max} \\
(5)\end{array}$ \\
\hline \multicolumn{6}{|l|}{ Antisemitism } \\
\hline Historical Antisemitism (VV P.C.) & 298 & -0.61 & 1.02 & -3.84 & 2.25 \\
\hline Medieval Antisemitism (Pogrom1349) & 307 & 0.54 & 0.50 & 0.00 & 1.00 \\
\hline Exposure to Jews pre- 1300 & 307 & 0.92 & 0.27 & 0.00 & 1.00 \\
\hline \multicolumn{6}{|l|}{ County characteristics } \\
\hline Log Jews 1933 & 307 & 5.43 & 1.76 & 0.00 & 11.99 \\
\hline Percentage unemployed 1933 & 307 & 16.24 & 8.26 & 2.62 & 40.52 \\
\hline Percentage blue collars 1933 & 307 & 42.86 & 11.32 & 16.49 & 72.40 \\
\hline Percentage self-employed 1933 & 307 & 21.01 & 4.55 & 9.10 & 32.74 \\
\hline Percentage Catholics 1925 & 307 & 36.75 & 34.62 & 0.50 & 98.77 \\
\hline Latitude & 443 & 50.64 & 1.72 & 47.95 & 54.03 \\
\hline Land-quality index & 442 & 0.56 & 0.14 & 0.31 & 0.87 \\
\hline Income per capita 2005 & 413 & 17,294 & 2,280 & 12,846 & 27,253 \\
\hline Population density 2005 & 425 & 2,308 & 2,549 & 546 & 29,036 \\
\hline Percentage college graduates 2005 & 430 & 24.49 & 5.03 & 17.60 & 34.60 \\
\hline \multicolumn{6}{|l|}{ Household characteristics } \\
\hline Holds stocks & 26,761 & 0.16 & 0.37 & 0.00 & 1.00 \\
\hline Homeowner & 27,064 & 0.39 & 0.49 & 0.00 & 1.00 \\
\hline Has life insurance & 26,761 & 0.47 & 0.50 & 0.00 & 1.00 \\
\hline Income & 26,761 & 31,522 & 26,614 & -36 & 986,400 \\
\hline Age & 21,981 & 48.62 & 17.64 & 17.00 & 97.00 \\
\hline Female & 21,982 & 0.49 & 0.50 & 0.00 & 1.00 \\
\hline Single & 27,064 & 0.18 & 0.38 & 0.00 & 1.00 \\
\hline High school or higher & 27,079 & 0.77 & 0.42 & 0.00 & 1.00 \\
\hline Eastern Germany & 27,079 & 0.13 & 0.34 & 0.00 & 1.00 \\
\hline
\end{tabular}


Table 2: Historical Antisemitism and Present-Day Stock Market Participation

This table reports average marginal effects computed after estimating the following probit specification:

$\operatorname{Pr}\left(\right.$ HoldsStocks $\left._{i k} \mid X_{i k}, K_{k}\right)=\Phi\left(\alpha+\beta \times\right.$ Historical Antisemitism ${ }_{k}+X_{i k}^{\prime} \times \gamma+K_{k}^{\prime} \times \delta+$ Income_deciles $\left._{+} \eta_{t}+\epsilon_{i k}\right)$

Each observation is a German household interviewed by SOEP between 1984 and 2011. In all columns, the dependent variable is a dummy that equals 1 if the household holds stocks. The main covariate of interest, Historical Antisemitism, is the Voigtlaender-Voth principal component (VV P.C.) of Jewish persecution in the 1920s-1930s,. $X_{i k}$ includes the following individual-level controls: gender, single-status dummy, age (second-degree polynomial), college-education dummy. Other individual controls include: homeownership dummy and life and social insurance dummy. Other historical controls include: log of population in 1933, ratio of population employed in the retail sector in 1933, and ratio of population employed in manufacturing in 1933. Other regional controls include: population density, latitude, index of quality of cultivable land. Income_deciles are dummies indicating the decile of the income distribution to which the household belongs, and $\Phi$ is the standard normal cdf. We cluster standard errors at the county level. $* p<0.10, * * p<0.05, * * * p<0.01$.

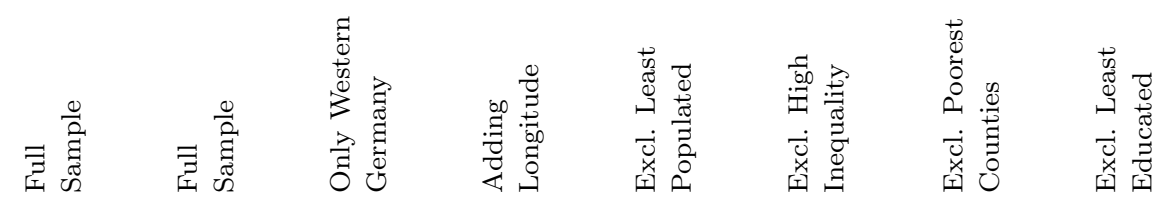

(1) (2) (3)

(4) (5)

(6)

(7)

(8)

\begin{tabular}{|c|c|c|c|c|c|c|c|c|}
\hline $\begin{array}{l}\text { Historical Antisemitism } \\
\text { (VV P.C.) }\end{array}$ & $\begin{array}{c}-0.009 * * \\
(0.005)\end{array}$ & $\begin{array}{l}-0.014 * * * \\
(0.004)\end{array}$ & $\begin{array}{l}-0.015 * * * \\
(0.005)\end{array}$ & $\begin{array}{c}-0.010^{* *} \\
(0.004)\end{array}$ & $\begin{array}{l}-0.013 * * * \\
(0.005)\end{array}$ & $\begin{array}{l}-0.016 * * * \\
(0.005)\end{array}$ & $\begin{array}{l}-0.020 * * * \\
(0.005)\end{array}$ & $\begin{array}{r}-0.013^{* *} \\
(0.005)\end{array}$ \\
\hline Log Jews 1933 & $\begin{array}{l}0.007 * * * \\
(0.003)\end{array}$ & $\begin{array}{c}0.003 \\
(0.005)\end{array}$ & $\begin{array}{c}0.000 \\
(0.005)\end{array}$ & $\begin{array}{l}-0.001 \\
(0.005)\end{array}$ & $\begin{array}{l}0.000 \\
(0.007)\end{array}$ & $\begin{array}{c}0.000 \\
(0.006)\end{array}$ & $\begin{array}{c}-0.003 \\
(0.007)\end{array}$ & $\begin{array}{c}0.004 \\
(0.006)\end{array}$ \\
\hline \% Catholics 1925 & & $\begin{array}{l}0.000 \\
(0.000)\end{array}$ & $\begin{array}{c}0.000 \\
(0.000)\end{array}$ & $\begin{array}{c}0.000 \\
(0.000)\end{array}$ & $\begin{array}{l}0.000 \\
(0.000)\end{array}$ & $\begin{array}{c}0.000 \\
(0.000)\end{array}$ & $\begin{array}{c}0.000 \\
(0.000)\end{array}$ & $\begin{array}{c}0.000 \\
(0.000)\end{array}$ \\
\hline Age & & $\begin{array}{c}-0.002 * \\
(0.001)\end{array}$ & $\begin{array}{c}-0.002 \\
(0.001)\end{array}$ & $\begin{array}{c}-0.002^{* *} \\
(0.001)\end{array}$ & $\begin{array}{c}-0.002 \\
(0.001)\end{array}$ & $\begin{array}{l}-0.003 * * * \\
(0.001)\end{array}$ & $\begin{array}{c}-0.003 * * \\
(0.001)\end{array}$ & $\begin{array}{c}-0.003^{* *} \\
(0.001)\end{array}$ \\
\hline $\operatorname{Age}^{2} / 100$ & & $\begin{array}{l}0.043 * * * \\
(0.011)\end{array}$ & $\begin{array}{l}0.044 * * * \\
(0.012)\end{array}$ & $\begin{array}{c}0.043^{* * *} \\
(0.011)\end{array}$ & $\begin{array}{l}0.041 * * * \\
(0.012)\end{array}$ & $\begin{array}{l}0.045 * * * \\
(0.012)\end{array}$ & $\begin{array}{l}0.048 * * * \\
(0.012)\end{array}$ & $\begin{array}{l}0.047^{* *} \\
(0.012)\end{array}$ \\
\hline Female & & $\begin{array}{c}-0.001 \\
(0.006)\end{array}$ & $\begin{array}{l}0.000 \\
(0.006)\end{array}$ & $\begin{array}{l}-0.002 \\
(0.006)\end{array}$ & $\begin{array}{l}0.000 \\
(0.007)\end{array}$ & $\begin{array}{l}0.000 \\
(0.007)\end{array}$ & $\begin{array}{c}-0.001 \\
(0.007)\end{array}$ & $\begin{array}{c}0.004 \\
(0.007)\end{array}$ \\
\hline Single & & $\begin{array}{l}0.060 * * * \\
(0.010)\end{array}$ & $\begin{array}{l}0.066 * * * \\
(0.010)\end{array}$ & $\begin{array}{c}0.053^{* * *} \\
(0.009)\end{array}$ & $\begin{array}{l}0.056 * * * \\
(0.010)\end{array}$ & $\begin{array}{l}0.047 * * * \\
(0.010)\end{array}$ & $\begin{array}{l}0.065 * * * \\
(0.010)\end{array}$ & $\begin{array}{c}0.050^{* * *} \\
(0.011)\end{array}$ \\
\hline College & & $\begin{array}{l}0.011 * * * \\
(0.004)\end{array}$ & $\begin{array}{l}0.011 * * * \\
(0.004)\end{array}$ & $\begin{array}{c}0.012^{* * * *} \\
(0.004)\end{array}$ & $\begin{array}{l}0.013 * * * \\
(0.004)\end{array}$ & $\begin{array}{l}0.013 * * * \\
(0.004)\end{array}$ & $\begin{array}{l}0.013 * * * \\
(0.004)\end{array}$ & $\begin{array}{c}0.010^{* *} \\
(0.004)\end{array}$ \\
\hline Eastern Germany & & $\begin{array}{c}-0.024 \\
(0.021)\end{array}$ & & $\begin{array}{l}-0.033^{*} \\
(0.018)\end{array}$ & $\begin{array}{c}-0.006 \\
(0.028)\end{array}$ & $\begin{array}{c}-0.030 \\
(0.019)\end{array}$ & $\begin{array}{c}-0.045 * \\
(0.024)\end{array}$ & $\begin{array}{l}-0.020 \\
(0.020)\end{array}$ \\
\hline Income p.c. 2005 & & $\begin{array}{l}0.005 * * * \\
(0.002)\end{array}$ & $\begin{array}{l}0.005 * * * \\
(0.002)\end{array}$ & $\begin{array}{c}0.005^{* * *} \\
(0.002)\end{array}$ & $\begin{array}{l}0.008 * * * \\
(0.002)\end{array}$ & $\begin{array}{l}0.003 \\
(0.003)\end{array}$ & $\begin{array}{l}0.007 * * * \\
(0.002)\end{array}$ & $\begin{array}{c}0.007^{* * *} \\
(0.002)\end{array}$ \\
\hline \% College graduates 2005 & & $\begin{array}{c}0.001 \\
(0.001)\end{array}$ & $\begin{array}{c}0.001 \\
(0.001)\end{array}$ & $\begin{array}{l}-0.001 \\
(0.001)\end{array}$ & $\begin{array}{c}0.000 \\
(0.002)\end{array}$ & $\begin{array}{c}0.001 \\
(0.002)\end{array}$ & $\begin{array}{c}-0.001 \\
(0.002)\end{array}$ & $\begin{array}{c}0.002 \\
(0.002)\end{array}$ \\
\hline Income deciles & & $\mathrm{X}$ & $\mathrm{X}$ & $\mathrm{X}$ & $\mathrm{X}$ & $\mathrm{X}$ & $\mathrm{X}$ & $\mathrm{X}$ \\
\hline Other individual controls & & $\mathrm{X}$ & $\mathrm{X}$ & $\mathrm{X}$ & $\mathrm{X}$ & $\mathrm{X}$ & $\mathrm{X}$ & $\mathrm{X}$ \\
\hline Other historical controls & & $\mathrm{X}$ & $\mathrm{X}$ & $\mathrm{X}$ & $\mathrm{X}$ & $\mathrm{X}$ & $\mathrm{X}$ & $\mathrm{X}$ \\
\hline Other regional controls & & $\mathrm{X}$ & $\mathrm{X}$ & $\mathrm{X}$ & $\mathrm{X}$ & $\mathrm{X}$ & $\mathrm{X}$ & $\mathrm{X}$ \\
\hline Wave groups f.e. & & $\mathrm{X}$ & $\mathrm{X}$ & $\mathrm{X}$ & $\mathrm{X}$ & $\mathrm{X}$ & $\mathrm{X}$ & $\mathrm{X}$ \\
\hline Observations & 13,599 & 13,599 & 12,701 & 13,599 & 11,168 & 11,012 & 11,144 & 10,128 \\
\hline N. of clusters & 261 & 261 & 226 & 261 & 188 & 206 & 200 & 191 \\
\hline (Pseudo-) R2 & 0.001 & 0.105 & 0.106 & 0.093 & 0.095 & 0.094 & 0.094 & 0.090 \\
\hline
\end{tabular}


Table 3: Historical Antisemitism, Mortgages, and Deposits

Columns (1)-(6) report average marginal effects computed after estimating the following probit specification:

$$
\operatorname{Pr}\left(\text { Depvar }_{i k} \mid X_{i k}, K_{k}\right)=\Phi\left(\alpha+\beta \times \text { Historical Antisemitism }_{k}+X_{i k}^{\prime} \times \gamma+K_{k}^{\prime} \times \delta+\text { Income_deciles }^{\prime} \eta_{t}+\epsilon_{i k}\right)
$$

Each observation is a German household interviewed by SOEP between 1984 and 2011.2 The main covariate of interest, Historical Antisemitism, is the Voigtlaender-Voth principal component (VV P.C.) of measures of Jewish persecution in the 1920s-1930s. $X_{i k}$ includes the following individual-level controls: gender, single status dummy, age (2nd degree polynomial), college education dummy. Other individual controls include: homeownership dummy and life and social insurance dummy. Other historical controls include: log of population in 1933, ratio of population employed in the retail sector in 1933 , and ratio of population employed in manufacturing in 1933. Other regional controls include: population density, latitude, index of quality of cultivable land. Income_deciles are dummies indicating the decile of the income distribution to which the household belongs, and $\Phi$ is the standard normal cdf. The outcome variable, Depvar ${ }_{i k}$, is a dummy that equals 1 if the household owns any real estate property in columns (1)-(2), a dummy that equals 1 if the household has ever had a mortgage outstanding in columns (3)-(4), and a dummy that equals 1 if the household declares they save part of their monthly income regularly in columns (5)-(6). Columns (7)-(8) report the results for a county-level OLS regression of the ratio of total bank deposits in each county to total assets of banks in the county. We aggregate the branch-level deposits and assets from Bankscope at the county level. We cluster standard errors at the county level. $* p<0.10, * * p<0.05, * * * p<0.01$.

\begin{tabular}{|c|c|c|c|c|c|c|c|c|}
\hline & \multicolumn{2}{|c|}{ Home Owner } & \multicolumn{2}{|c|}{ Has a Mortgage } & \multicolumn{2}{|c|}{$\begin{array}{l}\text { Regularly Saves } \\
\text { Part of Income }\end{array}$} & \multicolumn{2}{|c|}{$\begin{array}{l}\text { Deposits/Assets } \\
\text { Local Banks }\end{array}$} \\
\hline & Probit & Probit & Probit & Probit & Probit & Probit & OLS & OLS \\
\hline & (1) & $(2)$ & (3) & (4) & (5) & (6) & (7) & (8) \\
\hline $\begin{array}{l}\text { Historical Antisemitism } \\
\text { (VV P.C.) }\end{array}$ & $\begin{array}{r}-0.009 \\
(0.010)\end{array}$ & $\begin{array}{r}-0.008 \\
(0.011)\end{array}$ & $\begin{array}{c}-0.007 * * \\
(0.003)\end{array}$ & $\begin{array}{c}-0.007 * * \\
(0.003)\end{array}$ & $\begin{array}{c}0.006 \\
(0.007)\end{array}$ & $\begin{array}{c}0.005 \\
(0.020)\end{array}$ & $\begin{array}{c}-0.015^{* *} \\
(0.007)\end{array}$ & $\begin{array}{c}-0.015 * * \\
(0.006)\end{array}$ \\
\hline Log Jews 1933 & $\begin{array}{r}-0.007 \\
(0.011)\end{array}$ & $\begin{array}{r}-0.011 \\
(0.012)\end{array}$ & $\begin{array}{c}0.004 \\
(0.003)\end{array}$ & $\begin{array}{c}0.004 \\
(0.003)\end{array}$ & $\begin{array}{r}-0.001 \\
(0.009)\end{array}$ & $\begin{array}{r}-0.001 \\
(0.007)\end{array}$ & $\begin{array}{c}-0.025^{* *} \\
(0.011)\end{array}$ & $\begin{array}{c}-0.021 * * \\
(0.010)\end{array}$ \\
\hline \% Catholics 1925 & $\begin{array}{c}0.002 \\
(0.002)\end{array}$ & $\begin{array}{c}0.000 \\
(0.001)\end{array}$ & $\begin{array}{c}0.000 \\
(0.001)\end{array}$ & $\begin{array}{r}-0.001 \\
(0.001)\end{array}$ & $\begin{array}{c}0.000 \\
(0.001)\end{array}$ & $\begin{array}{c}0.000 \\
(0.001)\end{array}$ & $\begin{array}{c}0.000 \\
(0.001)\end{array}$ & $\begin{array}{c}0.000 \\
(0.001)\end{array}$ \\
\hline Age & $\begin{array}{c}0.000 \\
(0.002)\end{array}$ & $\begin{array}{l}-0.001 \\
(0.002)\end{array}$ & $\begin{array}{l}0.011 * * * \\
(0.001)\end{array}$ & $\begin{array}{l}0.01 * * * \\
(0.001)\end{array}$ & $\begin{array}{r}-0.001 \\
(0.002)\end{array}$ & $\begin{array}{l}-0.005 * * * \\
(0.002)\end{array}$ & $\begin{array}{l}-0.002 \\
(0.002)\end{array}$ & \\
\hline $\mathrm{Age}^{2} / 100$ & $\begin{array}{c}0.000 \\
(0.001)\end{array}$ & $\begin{array}{c}-0.001 \\
(0.001)\end{array}$ & $\begin{array}{c}-0.001 * * * \\
(0.000)\end{array}$ & $\begin{array}{c}-0.001 * * * \\
(0.000)\end{array}$ & $\begin{array}{l}0.001 * * * \\
(0.000)\end{array}$ & $\begin{array}{l}0.001 * * * \\
(0.000)\end{array}$ & & \\
\hline Female & $\begin{array}{c}0.019 * \\
(0.010)\end{array}$ & $\begin{array}{c}0.019 * \\
(0.010)\end{array}$ & $\begin{array}{r}-0.005 \\
(0.004)\end{array}$ & $\begin{array}{r}-0.004 \\
(0.004)\end{array}$ & $\begin{array}{c}-0.034 * * * \\
(0.009)\end{array}$ & $\begin{array}{c}-0.032 * * * \\
(0.008)\end{array}$ & & $\begin{array}{c}0.005 \\
(0.044)\end{array}$ \\
\hline Single & $\begin{array}{l}0.153 * * * \\
(0.013)\end{array}$ & $\begin{array}{l}0.147 * * * \\
(0.013)\end{array}$ & $\begin{array}{c}-0.001 \\
(0.006)\end{array}$ & $\begin{array}{c}0.006 \\
(0.007)\end{array}$ & $\begin{array}{l}0.077 * * * \\
(0.017)\end{array}$ & $\begin{array}{l}0.092 * * * \\
(0.018)\end{array}$ & & $\begin{array}{c}-0.035 \\
(0.072)\end{array}$ \\
\hline College & $\begin{array}{l}0.036 * * * \\
(0.006)\end{array}$ & $\begin{array}{l}0.033 * * * \\
(0.005)\end{array}$ & $\begin{array}{c}-0.001 \\
(0.002)\end{array}$ & $\begin{array}{c}0.003 \\
(0.002)\end{array}$ & $\begin{array}{c}-0.016 * * * \\
(0.005)\end{array}$ & $\begin{array}{l}-0.012 * * * \\
(0.005)\end{array}$ & & $\begin{array}{c}0.230 \\
(0.177)\end{array}$ \\
\hline Eastern Germany & $\begin{array}{c}0.068 \\
(0.049)\end{array}$ & $\begin{array}{c}0.065 \\
(0.048)\end{array}$ & $\begin{array}{c}-0.019 * \\
(0.011)\end{array}$ & $\begin{array}{c}-0.019 * \\
(0.010)\end{array}$ & $\begin{array}{c}0.005 \\
(0.030)\end{array}$ & $\begin{array}{c}0.005 \\
(0.028)\end{array}$ & & $\begin{array}{l}0.079 * * * \\
(0.020)\end{array}$ \\
\hline Income p.c. 2005 & $\begin{array}{c}-0.004 \\
(0.004)\end{array}$ & $\begin{array}{c}-0.003 \\
(0.004)\end{array}$ & $\begin{array}{c}0.001 \\
(0.001)\end{array}$ & $\begin{array}{c}0.002 \\
(0.001)\end{array}$ & $\begin{array}{c}0.003 \\
(0.003)\end{array}$ & $\begin{array}{c}0.001 \\
(0.003)\end{array}$ & & $\begin{array}{c}-0.001 \\
(0.007)\end{array}$ \\
\hline \% College graduates 2005 & $\begin{array}{c}0.001 \\
(0.030) \\
\end{array}$ & $\begin{array}{c}-0.003 \\
(0.003) \\
\end{array}$ & $\begin{array}{c}0.001 \\
(0.001) \\
\end{array}$ & $\begin{array}{c}0.001 \\
(0.001)\end{array}$ & $\begin{array}{c}0.001 \\
(0.002) \\
\end{array}$ & $\begin{array}{c}0.001 \\
(0.002) \\
\end{array}$ & & \\
\hline Income deciles & $\mathrm{X}$ & $\mathrm{X}$ & $\mathrm{X}$ & $\mathrm{X}$ & $\mathrm{X}$ & $\mathrm{X}$ & & \\
\hline Other individual controls & & $\mathrm{X}$ & & $\mathrm{X}$ & & $\mathrm{X}$ & & $\mathrm{X}$ \\
\hline Other historical controls & & $\mathrm{X}$ & & $\mathrm{X}$ & & $\mathrm{X}$ & & $\mathrm{X}$ \\
\hline Other regional controls & & $\mathrm{X}$ & & $\mathrm{X}$ & & $\mathrm{X}$ & & $\mathrm{X}$ \\
\hline Wave groups f.e. & & $\mathrm{X}$ & & $\mathrm{X}$ & & $\mathrm{X}$ & & \\
\hline Observations & 11,484 & 11,484 & 11,484 & 11,484 & 10,900 & 10,900 & 236 & 236 \\
\hline N. of clusters & 236 & 236 & 236 & 236 & 236 & 236 & & \\
\hline (Pseudo-) $\mathrm{R}^{2}$ & 0.05 & 0.06 & 0.16 & 0.18 & 0.09 & 0.11 & 0.07 & 0.19 \\
\hline
\end{tabular}




\section{Table 4: The Deep Roots of Antisemitism}

This Table reports average marginal effects computed after estimating the following probit specification:

$$
\operatorname{Pr}\left(\text { HoldsStocks }_{i k} \mid X_{i k}, K_{i k}\right)=\Phi\left(\alpha+\beta \times \text { Medieval Antisemitism }_{k}+X_{i k}^{\prime} \times \gamma+K_{i k}^{\prime} \times \delta+\text { Income_deciles }_{-}+\eta_{t}+\epsilon_{i k}\right)
$$

Each observation is a German household interviewed by the SOEP any time between 1984 and 2011. In all columns, the dependent variable is a dummy that equals 1 if the household holds stocks. The main covariate of interest, Medieval Antisemitism, is a dummy variable that equals 1 if a pogrom happened in county $k$ during the Black Death period (around 1349), and zero otherwise. Historical Antisemitism is the Voigtlaender-Voth principal component (VV P.C.) of measures of Jewish persecution in the 1920s1930s. $X_{i k}$ includes the following individual-level controls: gender, single/marital status, income (second-degree polynomial), age (second-degree polynomial); college education, homeownership, and life and social insurance. $K_{k}$ includes the following county-level current and historical controls: latitude, income per capita, share of college-educated population, index of quality of cultivable land, log of population in 1933, log of Jewish population in 1933, ratio of population employed in the retail sector in 1933 , ratio of population employed in manufacturing in 1933, and ratio of Catholic population in 1925. Income_deciles are dummies indicating the decile of the income distribution to which the household belongs, and $\Phi$ is the standard normal cdf. We cluster standard erorrs at the county level. $* p<0.10, * * p<0.05, * * * p<0.01$

\begin{tabular}{|c|c|c|c|c|c|c|c|c|}
\hline & \multicolumn{4}{|c|}{ Medieval Antisemitism } & \multicolumn{4}{|c|}{ Exposure to Jews } \\
\hline & 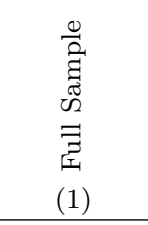 & 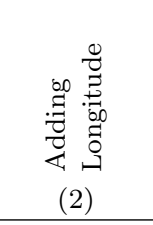 & 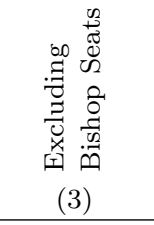 & 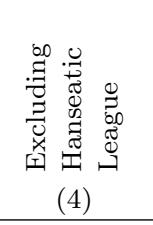 & 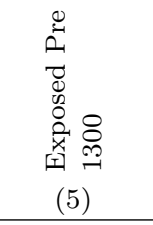 & 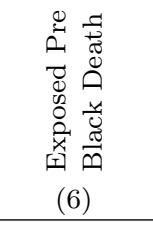 & 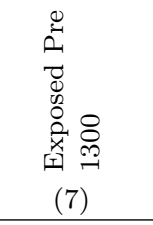 & 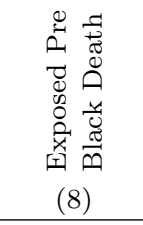 \\
\hline $\begin{array}{l}\text { Medieval Antisemitism } \\
\text { (Pogrom1349) }\end{array}$ & $\begin{array}{c}-0.020 * * \\
(0.009)\end{array}$ & $\begin{array}{r}-0.016 * \\
(0.009)\end{array}$ & $\begin{array}{r}-0.018 * \\
(0.010)\end{array}$ & $\begin{array}{r}-0.019 * \\
(0.010)\end{array}$ & $\begin{array}{c}-0.019 * * \\
(0.009)\end{array}$ & $\begin{array}{c}-0.019 * * \\
(0.009)\end{array}$ & & \\
\hline Exposure to Jews & & & & & $\begin{array}{c}-0.020 * * \\
(0.010)\end{array}$ & $\begin{array}{c}-0.024 * * \\
(0.010)\end{array}$ & $\begin{array}{c}-0.025 * * \\
(0.012)\end{array}$ & $\begin{array}{c}-0.030 * * \\
(0.012)\end{array}$ \\
\hline $\begin{array}{l}\text { Historical Antisemitism } \\
\text { (VV P.C.) }\end{array}$ & & & & & & & $\begin{array}{l}-0.014 * * * \\
(0.004)\end{array}$ & $\begin{array}{c}-0.014 * * * \\
(0.004)\end{array}$ \\
\hline Log Jews 1933 & $\begin{array}{r}-0.001 \\
(0.004)\end{array}$ & $\begin{array}{r}-0.003 \\
(0.004)\end{array}$ & $\begin{array}{c}0.001 \\
(0.004)\end{array}$ & $\begin{array}{r}-0.002 \\
(0.004)\end{array}$ & $\begin{array}{r}-0.001 \\
(0.004)\end{array}$ & $\begin{array}{r}-0.001 \\
(0.004)\end{array}$ & $\begin{array}{c}0.001 \\
(0.005)\end{array}$ & $\begin{array}{c}0.001 \\
(0.005)\end{array}$ \\
\hline \% Catholics 1925 & $\begin{array}{c}0.000 \\
(0.001)\end{array}$ & $\begin{array}{c}0.000 \\
(0.000)\end{array}$ & $\begin{array}{r}-0.000 \\
(0.000)\end{array}$ & $\begin{array}{r}-0.000 \\
(0.000)\end{array}$ & $\begin{array}{r}-0.000 \\
(0.000)\end{array}$ & $\begin{array}{r}-0.000 \\
(0.000)\end{array}$ & $\begin{array}{c}0.000 \\
(0.000)\end{array}$ & $\begin{array}{c}0.000 \\
(0.000)\end{array}$ \\
\hline Age & $\begin{array}{c}-0.002 * * \\
(0.001)\end{array}$ & $\begin{array}{c}-0.003 * * \\
(0.001)\end{array}$ & $\begin{array}{r}-0.002 * \\
(0.001)\end{array}$ & $\begin{array}{c}-0.003 * * \\
(0.001)\end{array}$ & $\begin{array}{c}-0.002 * * \\
(0.001)\end{array}$ & $\begin{array}{c}-0.002 * * \\
(0.001)\end{array}$ & $\begin{array}{c}-0.002 * \\
(0.001)\end{array}$ & $\begin{array}{r}-0.002 * \\
(0.001)\end{array}$ \\
\hline Age $\hat{2} / 100$ & $\begin{array}{l}0.046 * * * \\
(0.011)\end{array}$ & $\begin{array}{l}0.045 * * * \\
(0.011)\end{array}$ & $\begin{array}{l}0.044 * * * \\
(0.012)\end{array}$ & $\begin{array}{l}0.048 * * * \\
(0.012)\end{array}$ & $\begin{array}{l}0.046 * * * \\
(0.011)\end{array}$ & $\begin{array}{l}0.046 * * * \\
(0.011)\end{array}$ & $\begin{array}{l}0.043 * * * \\
(0.011)\end{array}$ & $\begin{array}{l}0.043 * * * \\
(0.011)\end{array}$ \\
\hline Female & $\begin{array}{c}-0.002 \\
(0.006)\end{array}$ & $\begin{array}{r}-0.003 \\
(0.006)\end{array}$ & $\begin{array}{r}-0.004 \\
(0.006)\end{array}$ & $\begin{array}{r}-0.003 \\
(0.007)\end{array}$ & $\begin{array}{c}-0.002 \\
(0.006)\end{array}$ & $\begin{array}{r}-0.002 \\
(0.006)\end{array}$ & $\begin{array}{c}-0.001 \\
(0.006)\end{array}$ & $\begin{array}{r}-0.005 \\
(0.006)\end{array}$ \\
\hline Single & $\begin{array}{l}0.060 * * * \\
(0.009)\end{array}$ & $\begin{array}{l}0.053 * * * \\
(0.009)\end{array}$ & $\begin{array}{l}0.060 * * * \\
(0.010)\end{array}$ & $\begin{array}{l}0.059 * * * \\
(0.010)\end{array}$ & $\begin{array}{l}0.060 * * * \\
(0.009)\end{array}$ & $\begin{array}{l}0.060 * * * \\
(0.009)\end{array}$ & $\begin{array}{l}0.060 * * * \\
(0.010)\end{array}$ & $\begin{array}{l}0.060 * * * \\
(0.010)\end{array}$ \\
\hline College & $\begin{array}{l}0.010 * * \\
(0.004)\end{array}$ & $\begin{array}{l}0.011 * * * \\
(0.004)\end{array}$ & $\begin{array}{l}0.012 * * * \\
(0.004)\end{array}$ & $\begin{array}{l}0.010 * * \\
(0.004)\end{array}$ & $\begin{array}{l}0.010 * * * \\
(0.004)\end{array}$ & $\begin{array}{l}0.010 * * * \\
(0.004)\end{array}$ & $\begin{array}{l}0.011 * * * \\
(0.004)\end{array}$ & $\begin{array}{l}0.011 * * * \\
(0.004)\end{array}$ \\
\hline Eastern Germany & $\begin{array}{c}-0.021 \\
(0.020)\end{array}$ & $\begin{array}{c}-0.031 * \\
(0.017)\end{array}$ & $\begin{array}{c}0.006 \\
(0.018)\end{array}$ & $\begin{array}{r}-0.001 \\
(0.021)\end{array}$ & $\begin{array}{c}-0.021 \\
(0.020)\end{array}$ & $\begin{array}{r}-0.021 \\
(0.020)\end{array}$ & $\begin{array}{c}-0.025 \\
(0.021)\end{array}$ & $\begin{array}{r}-0.026 \\
(0.021)\end{array}$ \\
\hline Income p.c. 2005 & $\begin{array}{c}0.003 * \\
(0.002)\end{array}$ & $\begin{array}{l}0.004 * * \\
(0.002)\end{array}$ & $\begin{array}{l}0.004 * * \\
(0.002)\end{array}$ & $\begin{array}{l}0.005 * * \\
(0.002)\end{array}$ & $\begin{array}{c}0.003 * \\
(0.002)\end{array}$ & $\begin{array}{c}0.003 * \\
(0.002)\end{array}$ & $\begin{array}{l}0.005 * * * \\
(0.002)\end{array}$ & $\begin{array}{l}0.004 * * * \\
(0.002)\end{array}$ \\
\hline \% College graduates 2005 & $\begin{array}{c}0.001 \\
(0.001)\end{array}$ & $\begin{array}{c}-0.001 \\
(0.001)\end{array}$ & $\begin{array}{c}0.001 \\
(0.001)\end{array}$ & $\begin{array}{c}0.001 \\
(0.001)\end{array}$ & $\begin{array}{c}0.001 \\
(0.001)\end{array}$ & $\begin{array}{c}0.001 \\
(0.001)\end{array}$ & $\begin{array}{c}0.001 \\
(0.001)\end{array}$ & $\begin{array}{c}0.001 \\
(0.001)\end{array}$ \\
\hline Income deciles & $\mathrm{X}$ & $\mathrm{X}$ & $\mathrm{X}$ & $\mathrm{X}$ & $\mathrm{X}$ & $\mathrm{X}$ & $\mathrm{X}$ & $\mathrm{X}$ \\
\hline Other historical controls & $\mathrm{X}$ & $\mathrm{X}$ & $\mathrm{X}$ & $\mathrm{X}$ & $\mathrm{X}$ & $\mathrm{X}$ & $\mathrm{X}$ & $\mathrm{X}$ \\
\hline Wave groups f.e. & $\mathrm{X}$ & $\mathrm{X}$ & $\mathrm{X}$ & $\mathrm{X}$ & $\mathrm{X}$ & $\mathrm{X}$ & $\mathrm{X}$ & $\mathrm{X}$ \\
\hline Regional controls & $\mathrm{X}$ & $\mathrm{X}$ & $\mathrm{X}$ & $\mathrm{X}$ & $\mathrm{X}$ & $\mathrm{X}$ & $\mathrm{X}$ & $\mathrm{X}$ \\
\hline Observations & 13,870 & 13,870 & 12,423 & 11,560 & 13,870 & 13,870 & 13,599 & 13,599 \\
\hline N. of clusters & 270 & 270 & 249 & 244 & 270 & 270 & 261 & 261 \\
\hline (Pseudo-) R2 & 0.106 & 0.093 & 0.093 & 0.094 & 0.106 & 0.106 & 0.106 & 0.106 \\
\hline
\end{tabular}




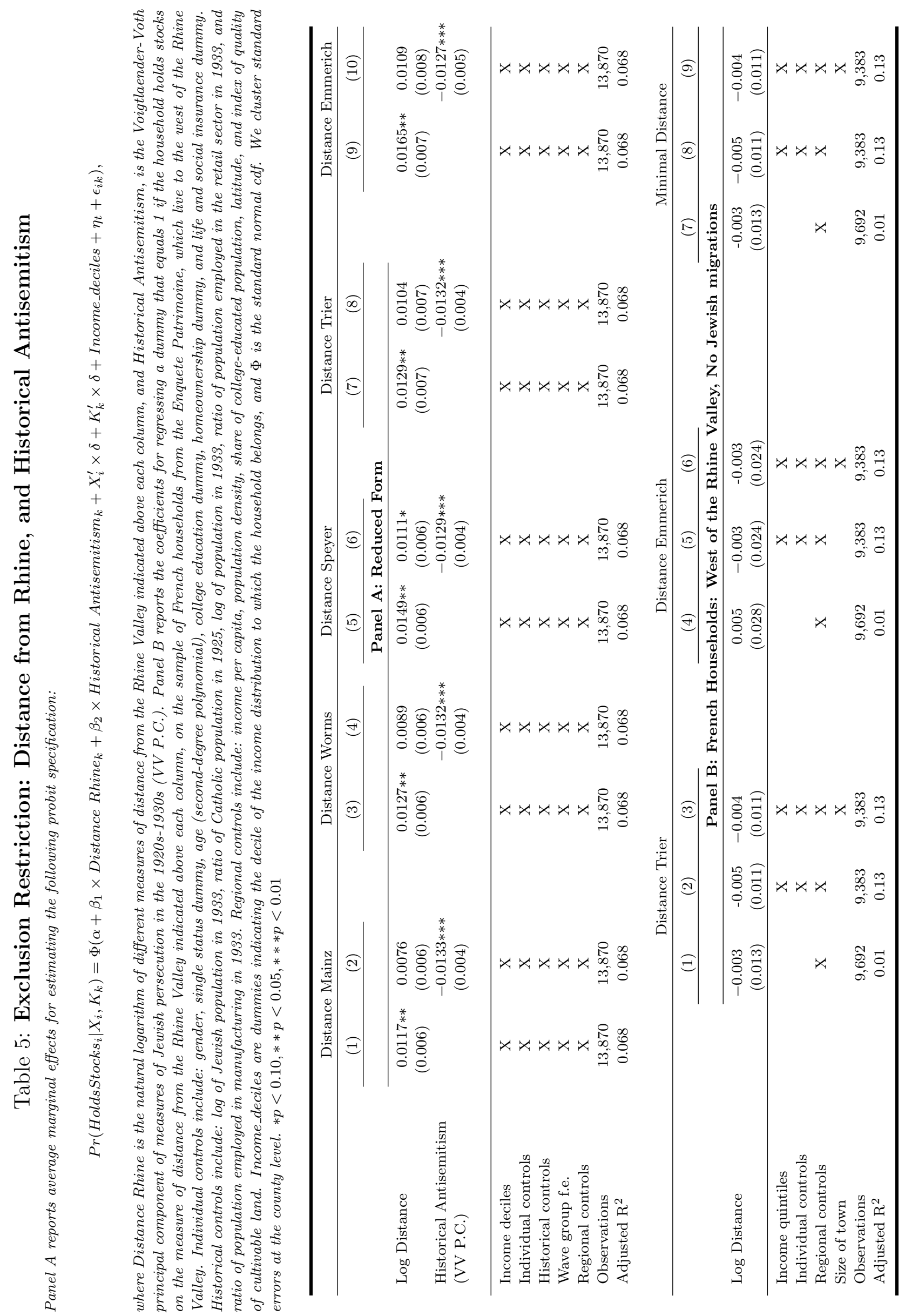




\section{Table 6: Three-Stage OLS: Distance from Rhine, Historical Antisemitism, Stockholdings}

This table reports OLS coefficients for the three-stage instrumental-variable procedure described in section 6 . In the first stage (Panel A), the probability that a Jewish community existed in 1349 in each German county is predicted by the distance of the county from the Rhine Valley. In the second stage (Panel B), the Voigtlaender and Voth (2012) principal component (VV P.C.) of measures of Jewish persecution in the 1920s and 1930 s is predicted with the predicted probability that a Jewish community existed in a county in 1349. In the third stage (Panel $C$ ), the ratio of households who own stocks in each county is predicted with the predicted extent of Jewish persecution. In all stages, coefficients are estimated with OLS. Individual controls include: gender, single status dummy, age (second-degree polynomial), college education dummy, homeownership dummy, and life and social insurance dummy. Historical controls include: log of Jewish population in 1933, ratio of Catholic population in 1925, log of population in 1933, ratio of population employed in the retail sector in 1933, and ratio of population employed in manufacturing in 1933. Regional controls include: income per capita, population density, share of college-educated population, latitude, and index of quality of cultivable land. We cluster standard errors at the county level. $* p<0.10, * * p<0.05, * * * p<0.01$.

\begin{tabular}{|c|c|c|c|c|c|}
\hline & $\begin{array}{l}\text { Distance } \\
\text { Mainz }\end{array}$ & $\begin{array}{c}\text { Distance } \\
\text { Worms }\end{array}$ & $\begin{array}{l}\text { Distance } \\
\text { Speyer }\end{array}$ & $\begin{array}{l}\text { Distance } \\
\text { Trier }\end{array}$ & $\begin{array}{c}\text { Distance } \\
\text { Emmerich }\end{array}$ \\
\hline \multicolumn{6}{|c|}{ Panel A. First Stage: Jewish Community Exists in 1349} \\
\hline & $(1)$ & $(2)$ & $(3)$ & $(4)$ & $(5)$ \\
\hline Log Distance & $\begin{array}{l}-0.227 * * * \\
(0.006)\end{array}$ & $\begin{array}{l}-0.199 * * * \\
(0.006)\end{array}$ & $\begin{array}{c}-0.186 * * * \\
(0.007)\end{array}$ & $\begin{array}{l}-0.131 * * * \\
(0.007)\end{array}$ & $\begin{array}{c}-0.196 * * * \\
(0.008)\end{array}$ \\
\hline Adj. $R^{2}$ & 0.35 & 0.34 & 0.33 & 0.30 & 0.32 \\
\hline \multicolumn{6}{|c|}{ Panel B. Second Stage: Historical Antisemitism (V.V. PC) } \\
\hline Existence 1349 & $\begin{array}{l}1.244 * * * \\
(0.050)\end{array}$ & $\begin{array}{l}1.375 * * * \\
(0.058)\end{array}$ & $\begin{array}{l}1.599 * * * \\
(0.064)\end{array}$ & $\begin{array}{l}2.418 * * * \\
(0.098)\end{array}$ & $\begin{array}{l}2.36 * * * \\
(0.070)\end{array}$ \\
\hline Adj. $\mathrm{R}^{2}$ & 0.51 & 0.50 & 0.51 & 0.51 & 0.52 \\
\hline \multicolumn{6}{|c|}{ Panel C. Third Stage: Holds Stocks } \\
\hline $\begin{array}{l}\text { Historical Antisemitism } \\
\text { (VV P.C.) }\end{array}$ & $\begin{array}{c}-0.044 * * \\
(0.021)\end{array}$ & $\begin{array}{c}-0.050 * * \\
(0.022)\end{array}$ & $\begin{array}{c}-0.053 * * \\
(0.021)\end{array}$ & $\begin{array}{c}-0.044 * * \\
(0.021)\end{array}$ & $\begin{array}{c}-0.035 * * \\
(0.016)\end{array}$ \\
\hline Adj. $\mathrm{R}^{2}$ & 0.08 & 0.08 & 0.08 & 0.08 & 0.08 \\
\hline Income deciles & $\mathrm{X}$ & $\mathrm{X}$ & $\mathrm{X}$ & $\mathrm{X}$ & $\mathrm{X}$ \\
\hline Individual controls & $\mathrm{X}$ & $\mathrm{X}$ & $\mathrm{X}$ & $\mathrm{X}$ & $\mathrm{X}$ \\
\hline Historical controls & $\mathrm{X}$ & $\mathrm{X}$ & $\mathrm{X}$ & $\mathrm{X}$ & $\mathrm{X}$ \\
\hline Regional controls & $\mathrm{X}$ & $\mathrm{X}$ & $\mathrm{X}$ & $\mathrm{X}$ & $\mathrm{X}$ \\
\hline Wave group f.e. & $\mathrm{X}$ & $\mathrm{X}$ & $\mathrm{X}$ & $\mathrm{X}$ & $\mathrm{X}$ \\
\hline Observations & 13,599 & 13,599 & 13,599 & 13,599 & 13,599 \\
\hline
\end{tabular}




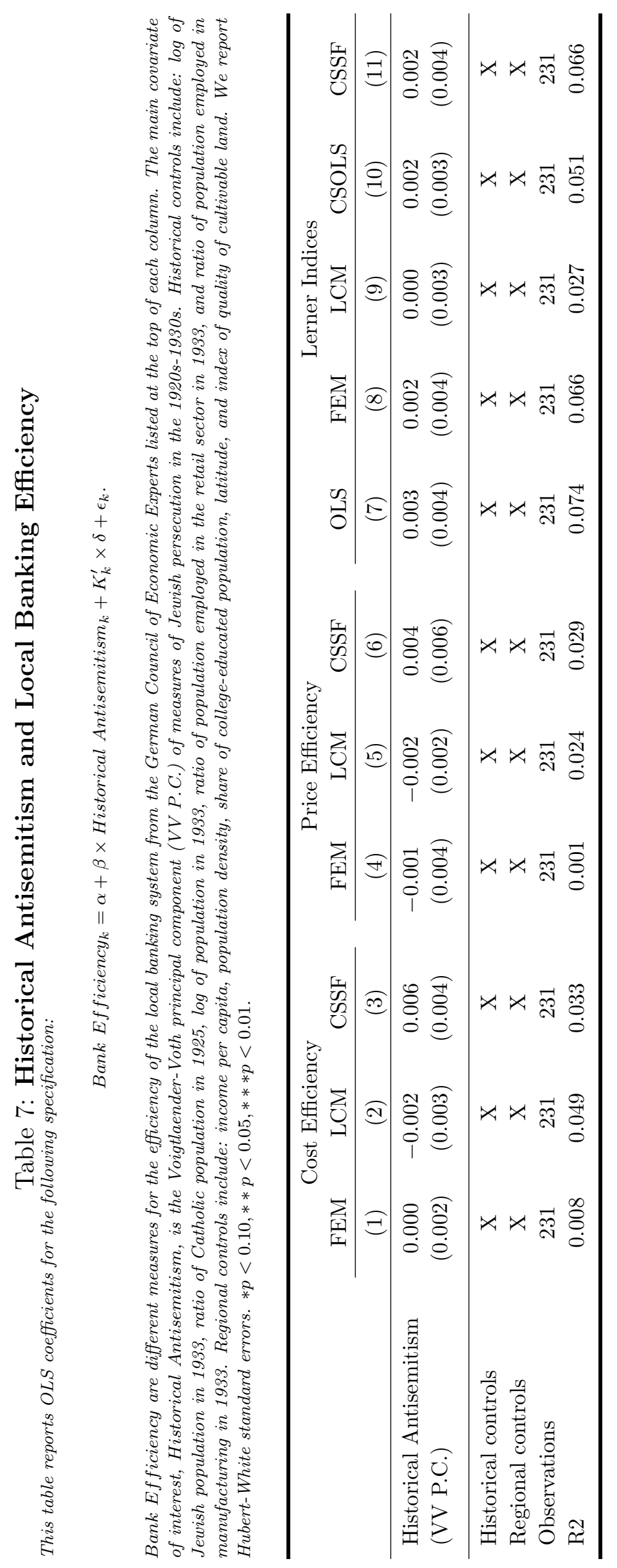




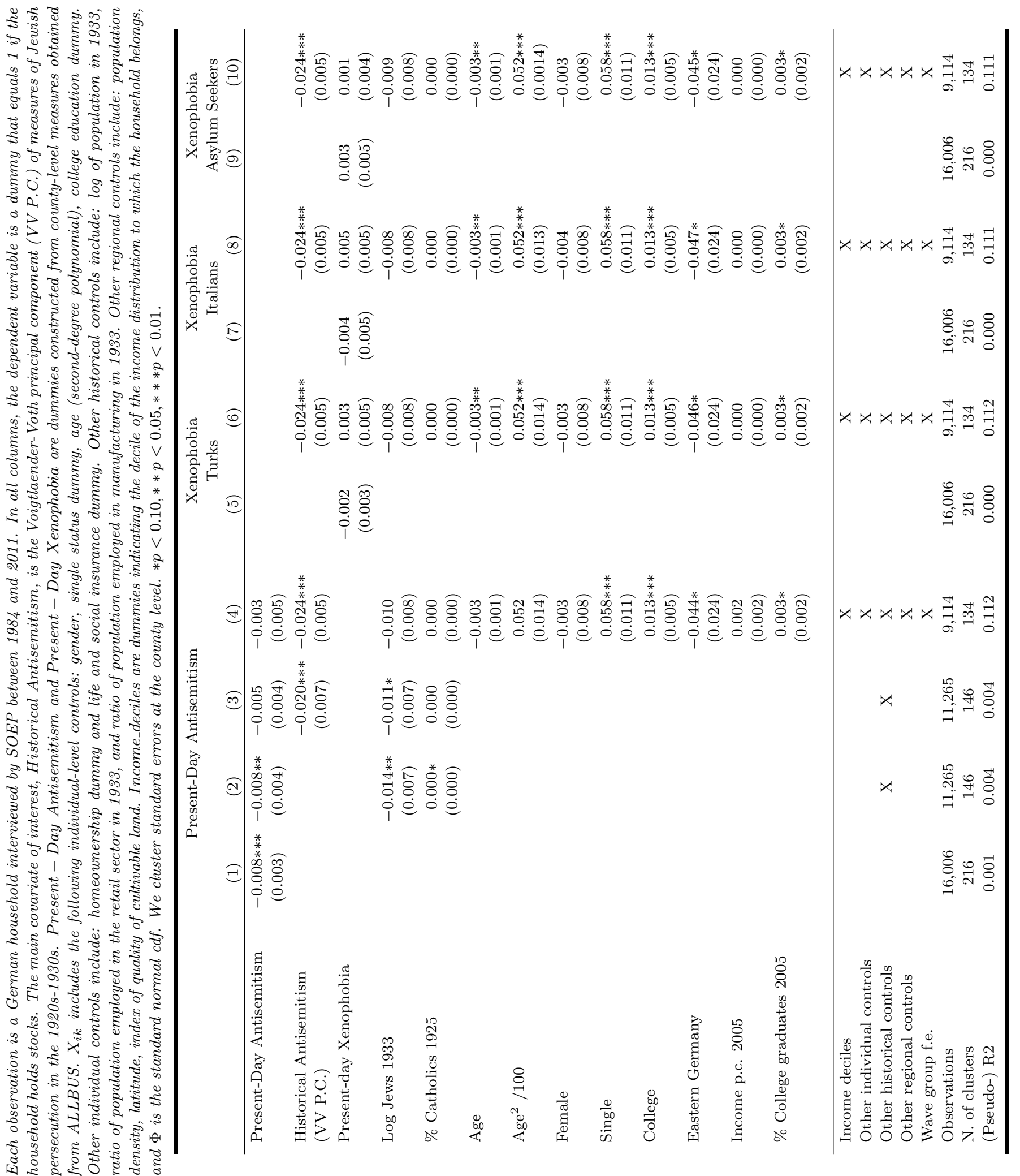




\section{Table 9: Historical Antisemitism, Distrust in Finance, and Financial Decisions}

This table reports average marginal effects computed after estimating the following probit spefication:

$$
\operatorname{Pr}\left(\text { Depvar }_{i k} \mid X_{i k}, K_{k}\right)=\Phi\left(\alpha+\beta \times \text { Historical Antisemitism }{ }_{k}+X_{k}^{\prime} \times \gamma+\epsilon_{i k}\right)
$$

where the main covariate of interest, Historical Antisemitism, is the Voigtlaender-Voth principal component (VV P.C.) of measures of Jewish persecution in the 1920s-1930s. $X_{i k}$ includes the following individual-level controls: gender, age-group fixed effects (15-28, 29-35, 36-45, 46-60, 61+), education-group fixed effects (Hauptschule, Realschule, Abitur, Hochschulabschluss), respondent's elicited generalized trust, respondent's elicited financial risk tolerance, and a dummy that equals 1 if the respondent resides in Eastern Germany. $\Phi$ is the standard normal cdf. The outcome variables, Depvar ${ }_{i k}$, are dummy variables indicated at the top of each column. The outcome variables and the household-level demographics are from our own survey of present-day Germans run by the company Clickworker, as described in section 7 of the paper. We cluster standard errors at the county level. $* p<0.10, * * p<0.05, * * * p<0.01$.

\begin{tabular}{|c|c|c|c|c|c|c|}
\hline & \multicolumn{6}{|c|}{ Panel A: Historical Antisemitism and Distrust in Finance } \\
\hline & \multicolumn{2}{|c|}{$\begin{array}{c}\text { Trust the } \\
\text { Stock Market }\end{array}$} & \multicolumn{2}{|c|}{$\begin{array}{l}\text { Trust Commercial } \\
\text { Banks }\end{array}$} & \multicolumn{2}{|c|}{$\begin{array}{l}\text { Trust Local } \\
\text { Banks }\end{array}$} \\
\hline & $(1)$ & $(2)$ & $(3)$ & $(4)$ & $(5)$ & $(6)$ \\
\hline $\begin{array}{l}\text { Historical Antisemitism } \\
\text { (VV P.C.) }\end{array}$ & $\begin{array}{c}-0.047 * * \\
(0.020)\end{array}$ & $\begin{array}{c}-0.041 * * \\
(0.018)\end{array}$ & $\begin{array}{r}-0.001 \\
(0.021)\end{array}$ & $\begin{array}{c}0.001 \\
(0.021)\end{array}$ & $\begin{array}{l}-0.083 * * * \\
(0.025)\end{array}$ & $\begin{array}{l}-0.082 * * * \\
(0.026)\end{array}$ \\
\hline Generalized Trust & $\begin{array}{r}-0.002 \\
(0.045)\end{array}$ & $\begin{array}{c}0.041 \\
(0.032)\end{array}$ & $\begin{array}{r}0.066 * \\
(0.039)\end{array}$ & $\begin{array}{r}0.078 * \\
(0.039)\end{array}$ & $\begin{array}{l}0.100 * * \\
(0.047)\end{array}$ & $\begin{array}{l}0.102 * * \\
(0.047)\end{array}$ \\
\hline Risk Tolerance, East DE & $\mathrm{X}$ & $\mathrm{X}$ & $\mathrm{X}$ & $\mathrm{X}$ & $\mathrm{X}$ & $\mathrm{X}$ \\
\hline Age group f.e. & & $\mathrm{X}$ & & $\mathrm{X}$ & & $\mathrm{X}$ \\
\hline Gender f.e. & & $\mathrm{X}$ & & $\mathrm{X}$ & & $\mathrm{X}$ \\
\hline Education group f.e. & & $\mathrm{X}$ & & $\mathrm{X}$ & & $\mathrm{X}$ \\
\hline Observations & 495 & 495 & 495 & 495 & 495 & 495 \\
\hline N. of clusters & 57 & 57 & 57 & 57 & 57 & 57 \\
\hline \multirow[t]{4}{*}{ Pseudo- $\mathrm{R}^{2}$} & 0.21 & 0.26 & 0.03 & 0.06 & 0.03 & 0.04 \\
\hline & \multicolumn{6}{|c|}{ Panel B: Distrust in Finance and Stock Market Participation } \\
\hline & \multicolumn{2}{|c|}{$\begin{array}{l}\text { Holds } \\
\text { Stocks }\end{array}$} & \multicolumn{2}{|c|}{$\begin{array}{l}\text { Relationship with } \\
\text { Commercial Banks }\end{array}$} & \multicolumn{2}{|c|}{$\begin{array}{c}\text { Relationship with } \\
\text { Local Banks }\end{array}$} \\
\hline & $(1)$ & $(2)$ & $(3)$ & $(4)$ & $(5)$ & $(6)$ \\
\hline Trust the Stock Market & $\begin{array}{l}0.224 * * * \\
(0.065)\end{array}$ & $\begin{array}{l}0.230 * * * \\
(0.062)\end{array}$ & $\begin{array}{c}0.032 \\
(0.070)\end{array}$ & $\begin{array}{r}-0.018 \\
(0.068)\end{array}$ & $\begin{array}{c}-0.093 * \\
(0.055)\end{array}$ & $\begin{array}{r}-0.076 \\
(0.057)\end{array}$ \\
\hline Trust Commercial Banks & $\begin{array}{c}0.070 \\
(0.060)\end{array}$ & $\begin{array}{c}0.060 \\
(0.061)\end{array}$ & $\begin{array}{l}0.260 * * * \\
(0.068)\end{array}$ & $\begin{array}{l}0.279 * * * \\
(0.065)\end{array}$ & $\begin{array}{l}-0.140 * * * \\
(0.051)\end{array}$ & $\begin{array}{c}-0.145 * * * \\
(0.049)\end{array}$ \\
\hline Trust Local Banks & $\begin{array}{c}0.014 \\
(0.049)\end{array}$ & $\begin{array}{c}0.011 \\
(0.048)\end{array}$ & $\begin{array}{r}-0.039 \\
(0.055)\end{array}$ & $\begin{array}{r}-0.049 \\
(0.051)\end{array}$ & $\begin{array}{l}0.203 * * * \\
(0.048)\end{array}$ & $\begin{array}{l}0.211 * * * \\
(0.045)\end{array}$ \\
\hline Generalized Trust & $\begin{array}{r}-0.011 \\
(0.044)\end{array}$ & $\begin{array}{r}-0.005 \\
(0.042)\end{array}$ & $\begin{array}{r}-0.089 * \\
(0.046)\end{array}$ & $\begin{array}{c}-0.090 * * \\
(0.043)\end{array}$ & $\begin{array}{l}0.096 * * * \\
(0.040)\end{array}$ & $\begin{array}{l}0.097 * * \\
(0.038)\end{array}$ \\
\hline Risk Tolerance, East DE & $\mathrm{X}$ & $\mathrm{X}$ & $\mathrm{X}$ & $\mathrm{X}$ & $\mathrm{X}$ & $\mathrm{X}$ \\
\hline Age group f.e. & & $\mathrm{X}$ & & $\mathrm{X}$ & & $\mathrm{X}$ \\
\hline Gender f.e. & & $\mathrm{X}$ & & $\mathrm{X}$ & & $\mathrm{X}$ \\
\hline Education group f.e. & & $\mathrm{X}$ & & $\mathrm{X}$ & & $\mathrm{X}$ \\
\hline Observations & 488 & 488 & 490 & 490 & 490 & 490 \\
\hline N. of clusters & 57 & 57 & 57 & 57 & 57 & 57 \\
\hline \multirow[t]{4}{*}{ Pseudo- $\mathrm{R}^{2}$} & 0.22 & 0.24 & 0.06 & 0.10 & 0.08 & 0.12 \\
\hline & \multicolumn{6}{|c|}{ Panel C: Historical Antisemitism and Stock Market Participation } \\
\hline & \multicolumn{2}{|c|}{$\begin{array}{l}\text { Hold } \\
\text { Stocks }\end{array}$} & \multicolumn{2}{|c|}{$\begin{array}{l}\text { Relationship with } \\
\text { Commercial Banks }\end{array}$} & \multicolumn{2}{|c|}{$\begin{array}{l}\text { Relationship with } \\
\text { Local Banks }\end{array}$} \\
\hline & $(1)$ & $(2)$ & $(3)$ & $(4)$ & $(5)$ & $(6)$ \\
\hline $\begin{array}{l}\text { Historical Antisemitism } \\
\text { (VV P.C.) }\end{array}$ & $\begin{array}{c}-0.016 * * \\
(0.007)\end{array}$ & $\begin{array}{c}-0.014 * * \\
(0.007)\end{array}$ & $\begin{array}{l}0.006 * * \\
(0.003)\end{array}$ & $\begin{array}{l}0.008 * * * \\
(0.003)\end{array}$ & $\begin{array}{c}0.006 \\
(0.006)\end{array}$ & $\begin{array}{c}0.006 \\
(0.007)\end{array}$ \\
\hline Generalized Trust & $\begin{array}{r}-0.002 \\
(0.046)\end{array}$ & $\begin{array}{c}0.004 \\
(0.045)\end{array}$ & $\begin{array}{c}-0.133 * * \\
(0.051)\end{array}$ & $\begin{array}{c}-0.127 * * * \\
(0.047)\end{array}$ & $\begin{array}{c}0.097 * \\
(0.054)\end{array}$ & $\begin{array}{l}0.098 * * \\
(0.048)\end{array}$ \\
\hline Risk Tolerance, East DE & $\mathrm{X}$ & $\mathrm{X}$ & $\mathrm{X}$ & $\mathrm{X}$ & $\mathrm{X}$ & $\mathrm{X}$ \\
\hline Age group f.e. & & $\mathrm{X}$ & & $\mathrm{X}$ & & $\mathrm{X}$ \\
\hline Gender f.e. & & $\mathrm{X}$ & & $\mathrm{X}$ & & $\mathrm{X}$ \\
\hline Education group f.e. & & $\mathrm{X}$ & & $\mathrm{X}$ & & $\mathrm{X}$ \\
\hline Observations & 342 & 342 & 344 & 344 & 344 & 344 \\
\hline N. of clusters & 42 & 42 & 42 & 42 & 42 & 42 \\
\hline Pseudo- $\mathrm{R}^{2}$ & 0.20 & $0.23 \quad 48$ & 0.03 & 0.10 & 0.02 & 0.09 \\
\hline
\end{tabular}




\section{Online Appendix:}

\section{Historical Antisemitism, Ethnic Specialization, and Financial Development}

Francesco D'Acunto, Marcel Prokopczuk, and Michael Weber

Not for Publication 


\section{Anti-Jewish Ideology, Nazi Votes, and Stockholdings}

Incentives unrelated to antisemitism may have driven Jewish persecution. For instance, individuals and political leaders may have hoped to seize Jewish property if they took part in or promoted the attacks against Jews.

We therefore study the association between historical antisemitism and current stockholdings, using a source of variation of ideological anti-Jewish sentiment different from persecution, namely, voting. Unlike persecution, voting is unobservable and not verifiable. Voting choices were unlikely to raise the expectation of rewards by the Nazis before the start of the Third Reich. The Nazis rose to power during a long and deep economic crisis: hyperinflation was a major concern, and unemployment plagued several counties. Many voters supported the Nazi party (which had not been in power before 1933) in the hope of improving their economic conditions. de Bromhead, Eichengreen, and O'Rourke (2013) show that persistently depressed economic conditions are a strong predictor of the electoral support of right-wing, anti-system parties in Europe in the 1930s. Thus, voting for the Nazi party in 1933 should be a valid proxy for anti-Jewish sentiment in areas where unemployment in 1933 was low. The economic crisis was less severe in those areas, and votes for the Nazis were more likely to capture the local support for their ideological platform. By contrast, votes for the Nazis should be a noisier proxy for anti-Jewish sentiment in counties where unemployment was high, that is, where voters were likely driven by economic motives when voting for the Nazis. This argument does not imply the Nazis had higher support, on average, in counties with higher unemployment, ${ }^{1}$ but it exploits the different motives within the group of Nazi voters in 1933.

If indeed past anti-Jewish sentiment reduces stock market participation, we would expect a negative association between Nazi vote shares in 1933 and present-day stockholdings in counties where unemployment was low in 1933, and a less negative effect in other counties. We find exactly this pattern. In Figure A.3, the left vertical axis reports the average marginal effect of the Nazi vote share in 1933 elections on households' stockholdings, and is associated with the histograms. The horizontal axis indicates the percentile of the distribution of counties by the unemployment rate in 1933. We sort counties in cumulative percentiles of this distribution. For instance, the histogram labeled "20" reports the average marginal

\footnotetext{
${ }^{1}$ In fact, King, Rosen, Tanner, and Wagner (2008) find that voters hit by the economic crisis but without a high risk of unemployment supported the Nazi party in 1933.
} 
effect for households in counties in which the unemployment rate in 1933 was below the $20^{\text {th }}$ percentile. The right vertical axis reports the standard errors attached to the marginal effects, which are clustered at the county level. They are associated with the black line. The average marginal effect of Nazi vote shares in 1933 is negative in counties with low unemployment in 1933, up to the $45^{\text {th }}$ percentile of the distribution. The magnitude of the effect and its statistical significance decrease up to the $80^{\text {th }}$ percentile. The effect becomes economically and statistically insignificant once we add households in counties above the $85^{\text {th }}$ percentile of the distribution of unemployment in 1933.

In Figure A.4 of the Online Appendix, we find a virtually identical pattern to that in Figure A.3 for the September 1930 elections. These elections were held during the economic crisis but in a time when the Nazis had no control of the German mass media, such as the radio (Adena, Enikolopov, Petrova, Santarosa, and Zhuravskaya, 2015). We also propose a set of placebo analyses to corroborate our interpretation of the evidence. Figure A.4 of the Online Appendix shows that votes for the Social-Democrats or Communists do not predict the same pattern as Nazi votes. Whereas the economic motives to vote for these parties might be similar to the motives to vote for the Nazis, these parties should not have attracted antisemite more than the Nazis. In Panels (d), (e), and (f), we show the Nazi votes are uncorrelated with the likelihood that households invest in life insurance products, that the household head is a woman, or with household income. ${ }^{2}$

\section{Additional Robustness Checks}

We check the robustness of the negative association between historical antisemitism and present-day stock market participation by considering partitions of the full sample and adding additional covariates.

In Table A.1, we first add religiosity from the world value survey in column (1). Column (2) excludes current households in counties that were wealthy in the distant past, that is, counties hosting any Hanseatic League cities, and column (3) excludes counties whose cities hosted at least one bishop seat. The rationale for the latter exclusion is that in counties with bishop seats, the ban on locals to engage in moneylending might have been enforced more strictly than in other counties, and at the same time, a culture of distrust

\footnotetext{
${ }^{2}$ In unreported results, we also find no significant associations if using the age, the education level, or the homeownership status of the household head as alternative outcomes.
} 
toward moneylending might have been stronger. Across all columns, we confirm our baseline findings.

Table A.2 augments equation 1 with geographic fixed effects, which only exploit the variation in Jewish persecution across counties close in space. In column (1), we look at counties in the same state (Bundesland). Counties in the same state are exposed to the same current institutions, but are not necessarily exposed to the same historical institutions, because the borders of states do not always coincide with the borders of historical administrative regions. Moreover, some states consist of a few counties, and hence have minor variation in Jewish persecution. To address these issues, in columns (2)-(3) of Table A.2 , we divide Germany into 9 and 16 arbitrary squares of similar size by longitude and latitude, which we label "virtual states." We only exploit the variation in Jewish persecution across counties that fall in the same squares. ${ }^{3}$ This method also overcomes the endogeneity of state borders. In column (4) of Table A.2, we only exploit the variation in Jewish persecution within occupation zones after the Second World War. These zones do not perfectly overlap with the present-day state boundaries, and occupants implemented different denazification policies across zones. All specifications replicate the baseline results. In column (5), we estimate the baseline specification at the county level. This test addresses the concern that individual observations in a county may be spatially correlated in a way not properly accounted for by the clustering of the standard errors at the county level. Across all specifications, the results are similar to the baseline analysis.

\footnotetext{
${ }^{3}$ Figure A.7 of the Online Appendix plots the composition of the virtual states.
} 
Figure A.1: Medieval Jewish Persecution: Pogroms during the Black Death around 1349

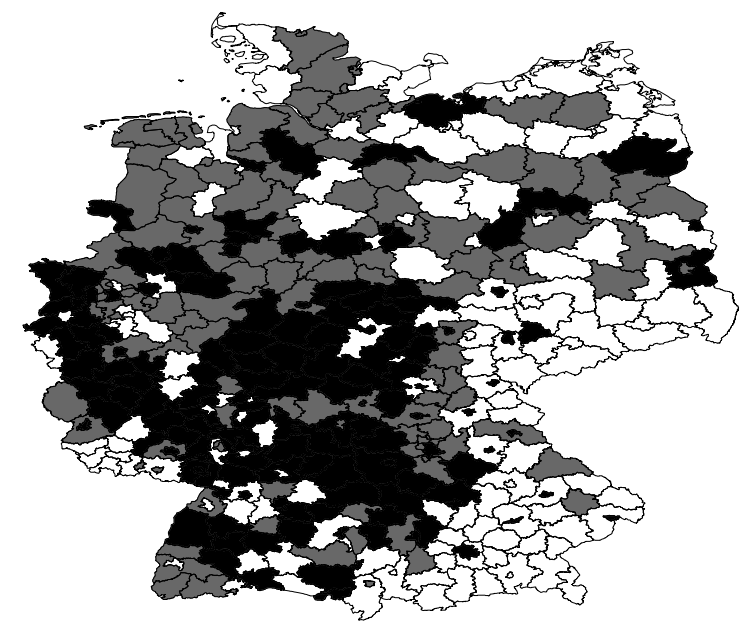

The figure plots the values of our proxy for historical Jewish persecution in the Middle Ages - a dummy variable for whether a pogrom against the local Jewish communities in a county was documented in 1349. Black counties are those for which we observe a pogrom against the local Jewish community in 1349, whereas grey counties are those for which we observe no pogroms despite the presence of a community in 1349. Blank counties are those for which we observe no communities in 1349, or we have no data about medieval Jewish persecution. 
Figure A.2: Historical Antisemitism and Stockholdings: Raw Data

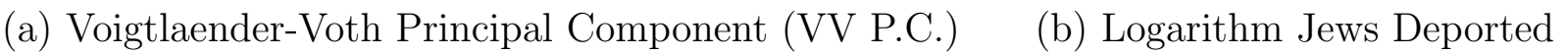

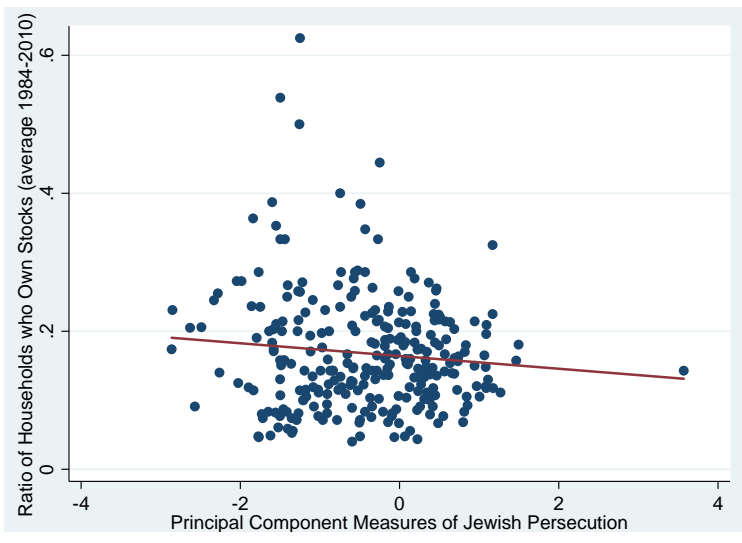

(c) Ratio Jews Deported

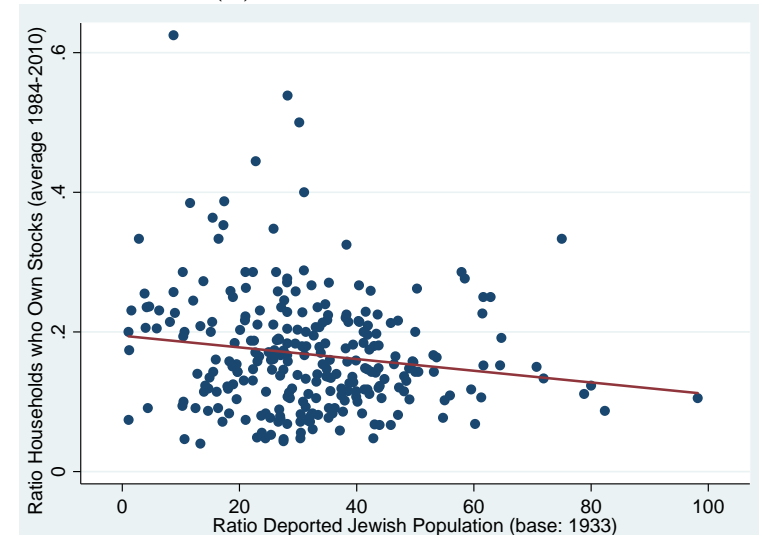

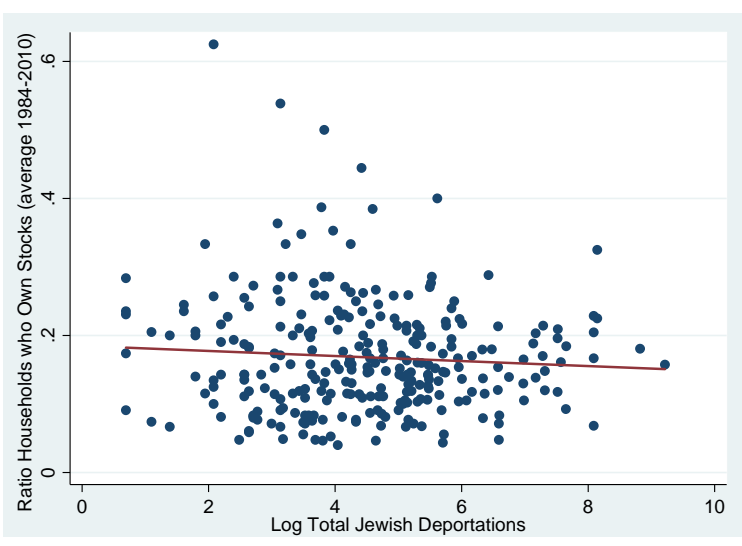

(d) Pogrom in 1349

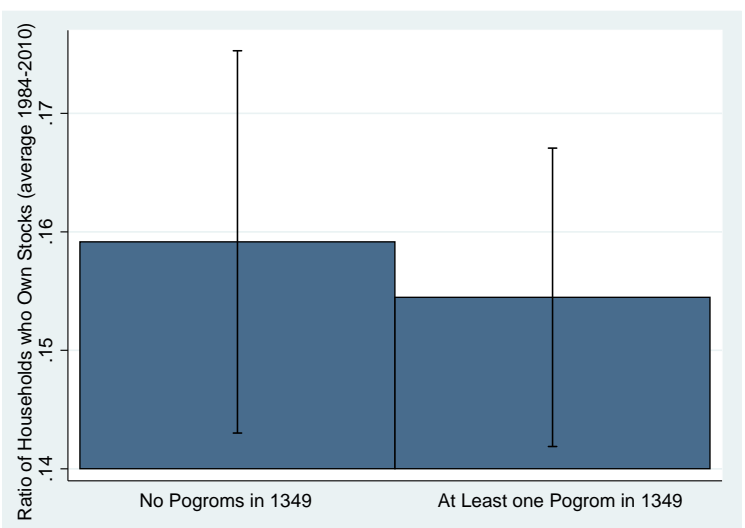

The figures plot the correlation between proxies of historical antisemitism and current-day stock market participation at the county level. We average the micro data from the SOEP to obtain measures of stock market participation at the county level. The sample period is 1984-2011. 
Figure A.3: Nazi Votes, Economic Crisis, and Stock Market Participation

\section{Percentile county-level unemployment 1933}

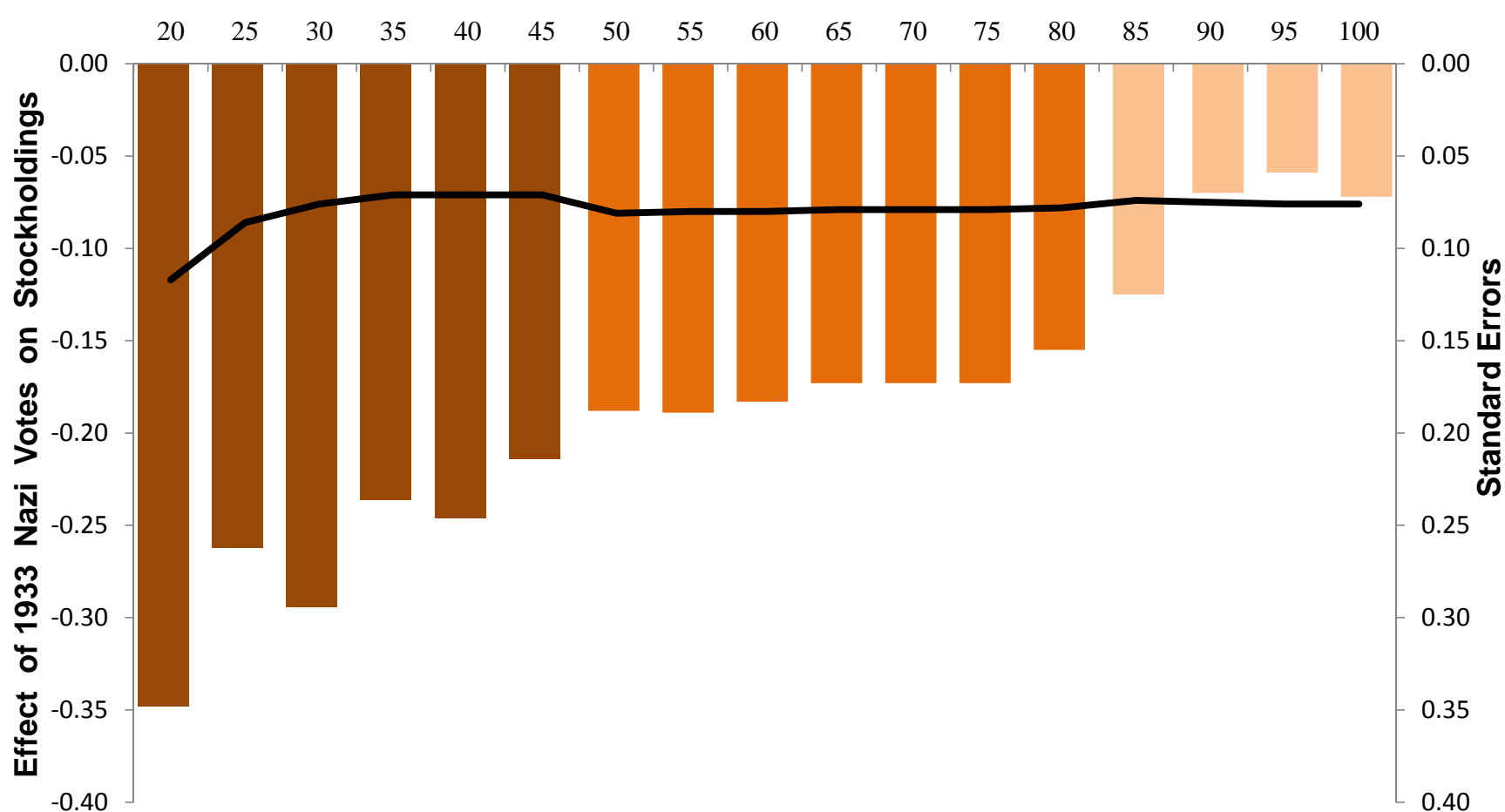

The figure plots the average marginal effects of the variable VoteShareNazi1933 on current-day stock market participation computed after estimating the following probit specification in subsamples of households sorted by the unemployment rate in their county of residence as of 1933:

$$
\operatorname{Pr}\left(\text { HoldsStocks }_{i k} \mid X_{i}, K_{k}\right)=\Phi\left(\alpha+\beta \times \text { VoteShareNazi1933 }{ }_{k}+X_{i}^{\prime} \times \gamma+K_{k}^{\prime} \times \delta+\eta_{t}+\epsilon_{i k}\right) .
$$

Each observation is a German household interviewed by SOEP between 1984 and 2011. The left vertical axis reports the average marginal effect of VoteShareNazi1933, and it is associated with the histograms. The horizontal axis indicates the percentile of the distribution of counties by the unemployment rate in 1933. For instance, the histogram labeled "20" reports the average marginal effect for estimating the probit model only for households that live in counties where the unemployment rate in 1933 was below the $20^{\text {th }}$ percentile; the histogram labeled "30" reports the average marginal effect for estimating the probit model only for households that live in counties where the unemployment rate in 1933 was below the $30^{\text {th }}$ percentile. The right vertical axis reports standard errors attached to each marginal effect. We cluster standard errors at the county level, and they are associated with the black line. Dark brown histograms are marginal effects that are significant at the $1 \%$ level or lower; orange histograms, at the $5 \%$ level; white histograms are not significant at any conventional level. 
Figure A.4: Votes and Placebo Outcomes

Nazi Votes in 1930

SPD Votes in 1933

KPD Votes in 1933
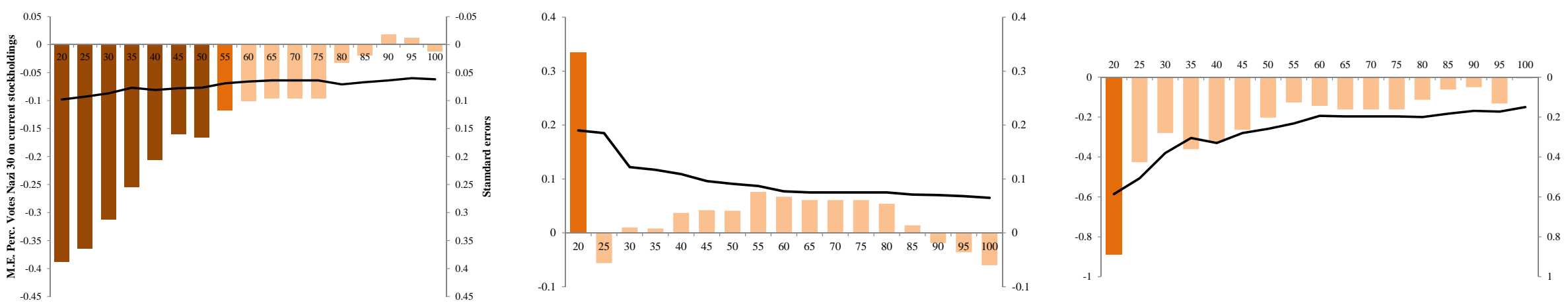

Female Household Head
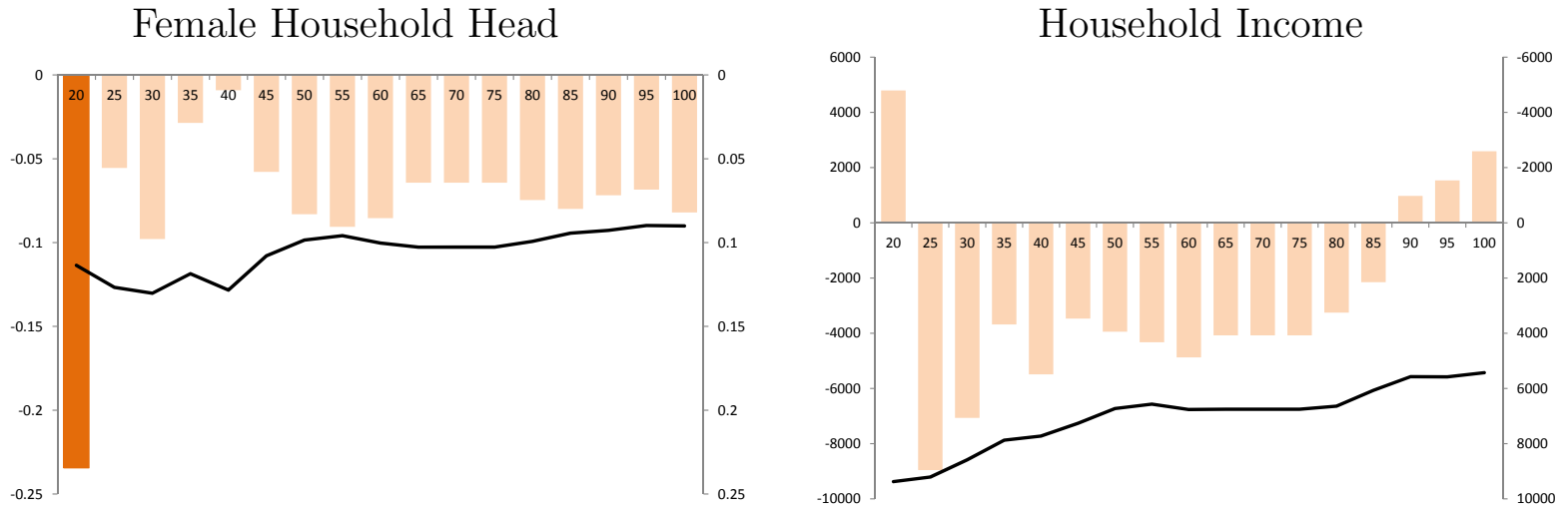

Invest in Life Insurance

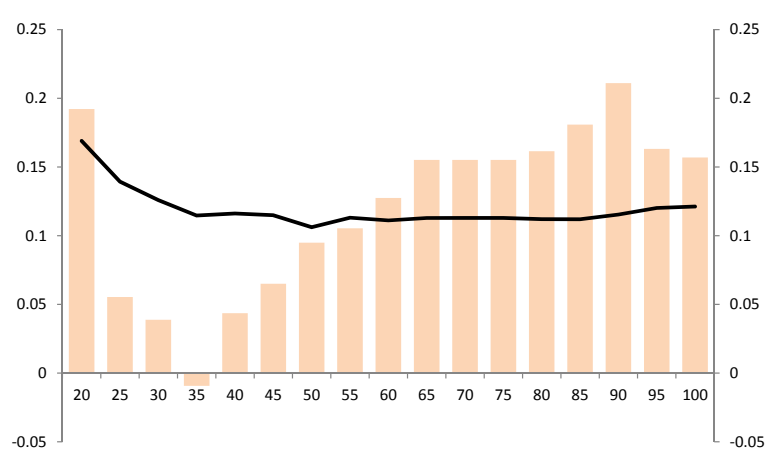

The figure plots the average marginal effects of the variables listed on top of each figure for the top panel on current-day stock market participation computed after estimating the probit specification of Figure A.3 or the following OLS specifications for the bottom panel in subsamples of households sorted by the unemployment rate in their county of residence as of 1933:

$$
\operatorname{DepVar}_{i k}=\alpha+\beta \times \text { VoteShare }_{k}+X_{i}^{\prime} \times \gamma+K_{k}^{\prime} \times \delta+\eta_{t}+\epsilon_{i k} .
$$

Each observation is a German household interviewed by SOEP between 1984 and 2011. DepVar is indicated on top of each figure for the bottom three figures. In each graph, the left vertical axis reports the OLS coefficient on VoteShare, and it is associated with the histograms. In the top panel, VoteShare is indicated on top of each figure, whereas it is VoteShareNazi1933 in the bottom panel. The horizontal axis indicates the percentile of the distribution of counties by the unemployment rate in 1933. For instance, the histogram labeled "20" reports the average marginal effect for estimating the OLS coefficient only for households that live in counties where the unemployment rate in 1933 was below the $20^{\text {th }}$ percentile; the histogram labeled "30" reports the OLS coefficient only for households which live in counties where the unemployment rate in 1933 was below the $30^{\text {th }}$ percentile. The right vertical axis reports standard errors attached to each coefficient. We cluster standard errors at the county level, and they are associated with the black line. Dark brown histograms are marginal effects that are significant at the $1 \%$ level or lower; orange histograms, at the $5 \%$ level; white histograms are not significant at any conventional level. 
Figure A.5: Supply-Side Channel 2: Historical Antisemitism \& Spread of Credit Unions

(a) Diffusion Path of Credit Unions Across Space and Over Time

Until 1860

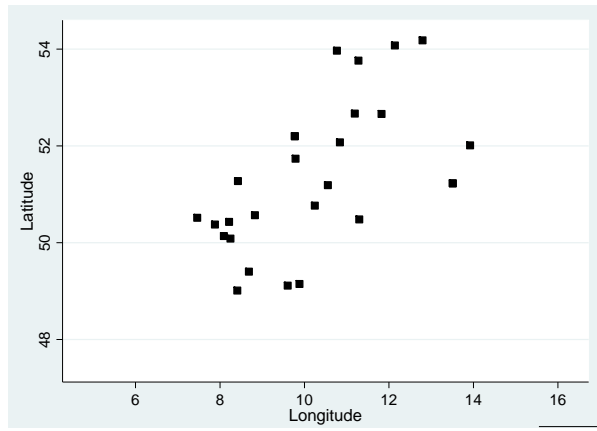

Until 1900

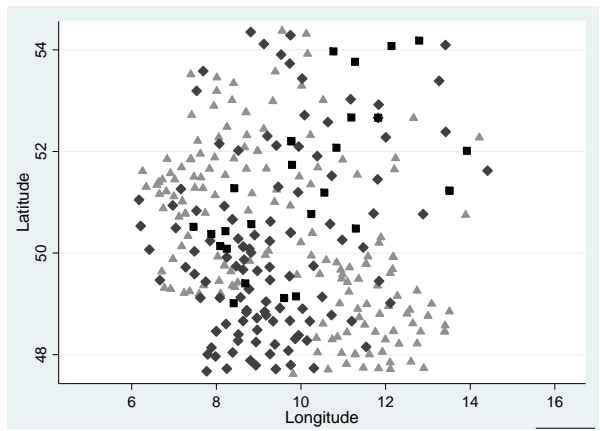

Until 1875

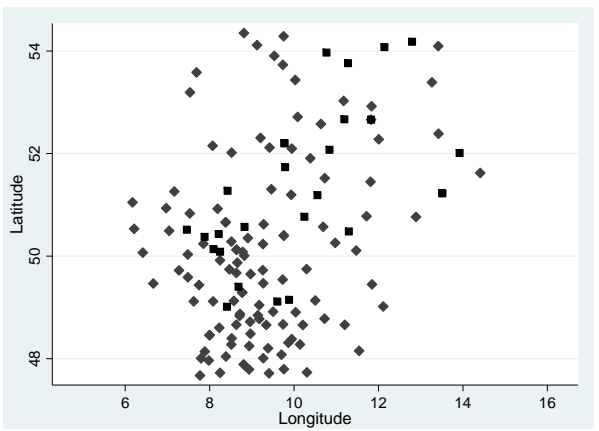

Up to the present

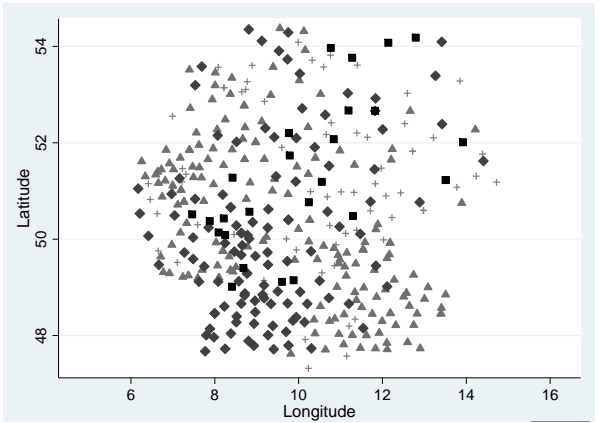

(b) Historical Antisemitism and the Foundation of Credit Unions

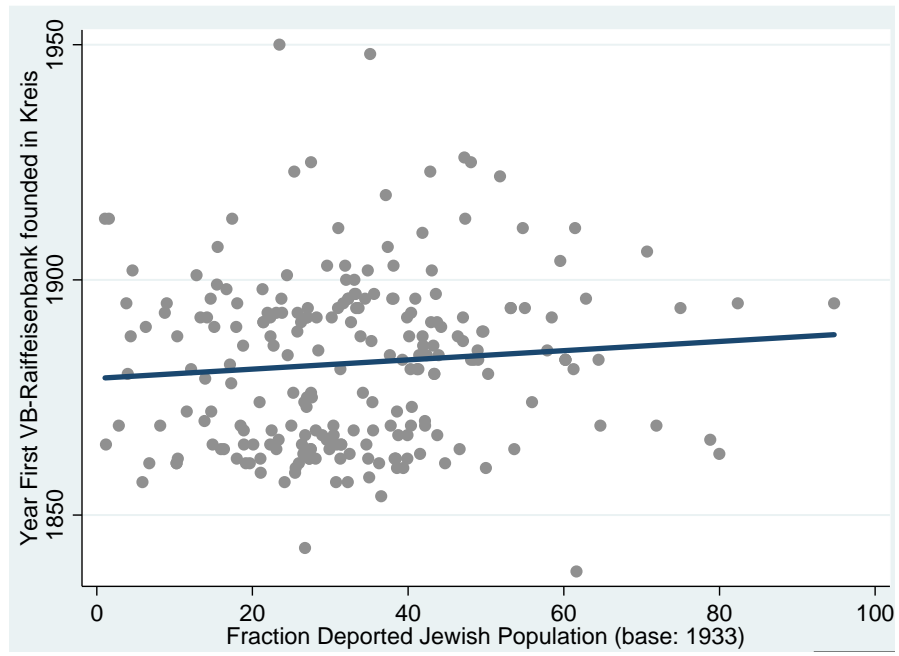

Panel (a) plots the Germans counties with existing credit unions at different points in time. Each marker represents a different county. Panel (b) plots the correlation between the founding year of the first credit union in a given county and the ratio of Jews deported during the Nazi period over the total Jewish population in 1933. The underlying data on the foundation dates is obtained from the Hoppenstedt database. 
Figure A.6: Supply-Side Channel 3: Jews in Finance \& Present-Day Stockholdings

(a) Ratio of Jews in Finance in 1882 and Present-Day Stockholdings

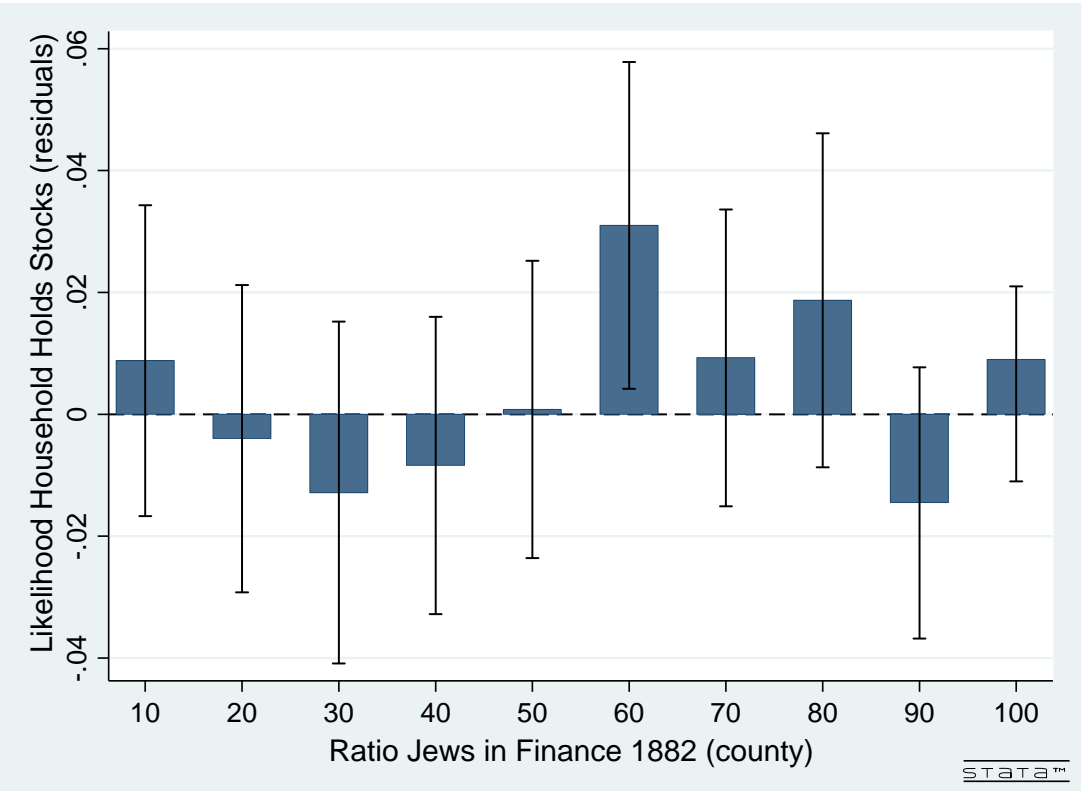

(b) Ratio of Jews in 1933 and Present-Day Stockholdings

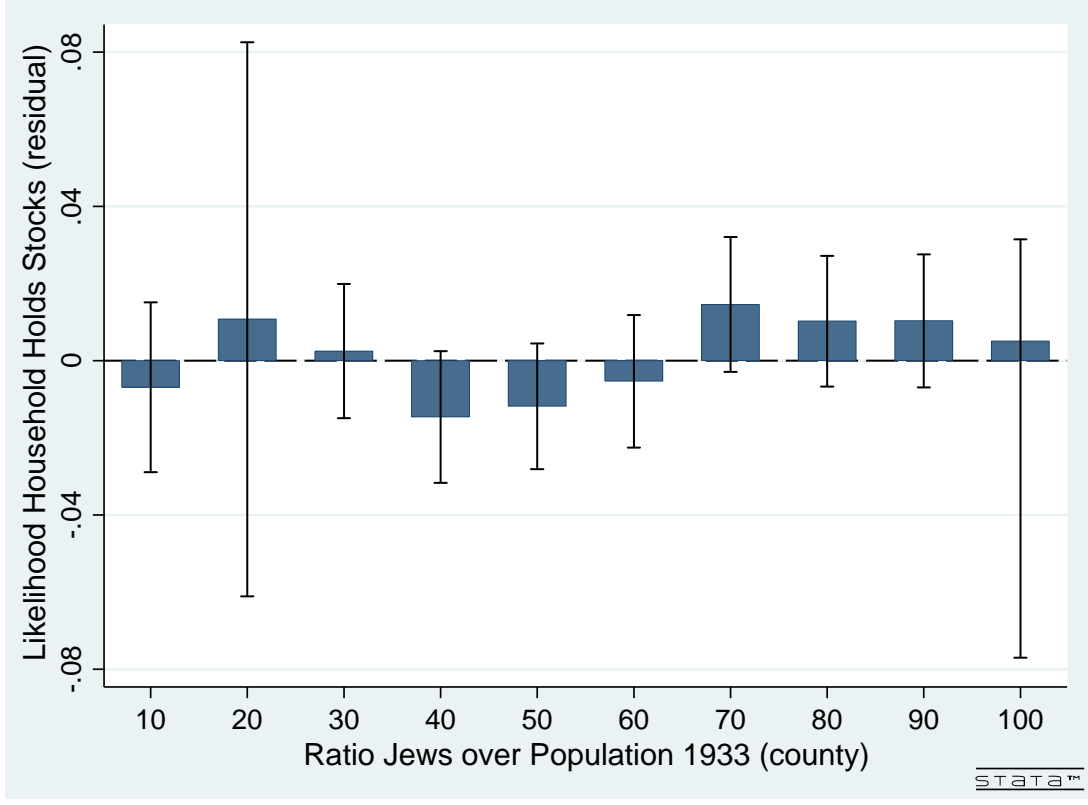

This figure plots the average residuals from regressing a dummy that equals 1 if the household holds stocks on the controls of equation (1) in the main body of the paper, across the deciles of the distribution of the share of Jewish employees in the financial sector in a county as of 1882 in Panel (a) and of the ratio of Jews over the total German population in a county as of 1933 in Panel (b). Intervals represent 95\% confidence intervals for the estimated averages. We use the micro data underlying SOEP to measure stock market participation, and the Ifo Prussian Economic History Database to measure the share of employees in the financial sector. 
Figure A.7: Virtual States

(a) 9 Virtual States

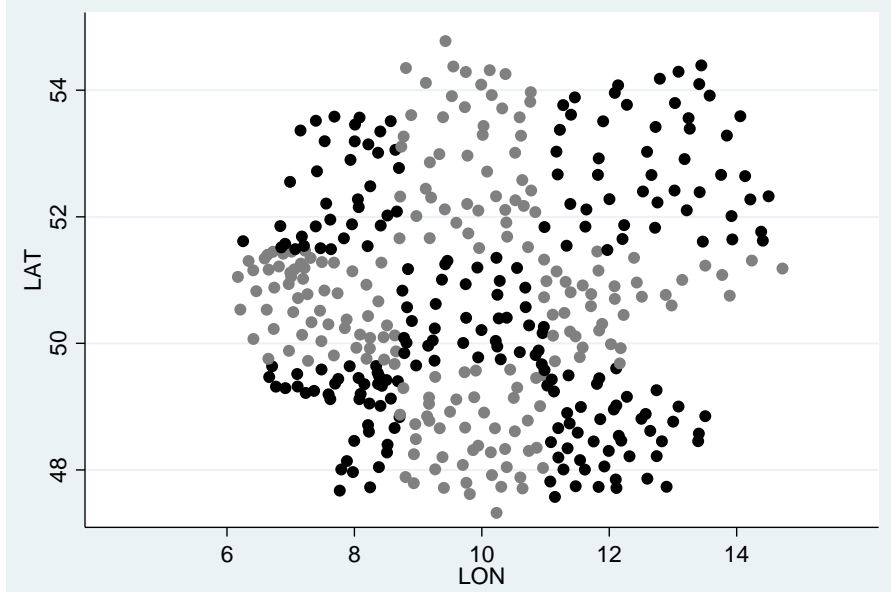

(b) 16 Virtual States

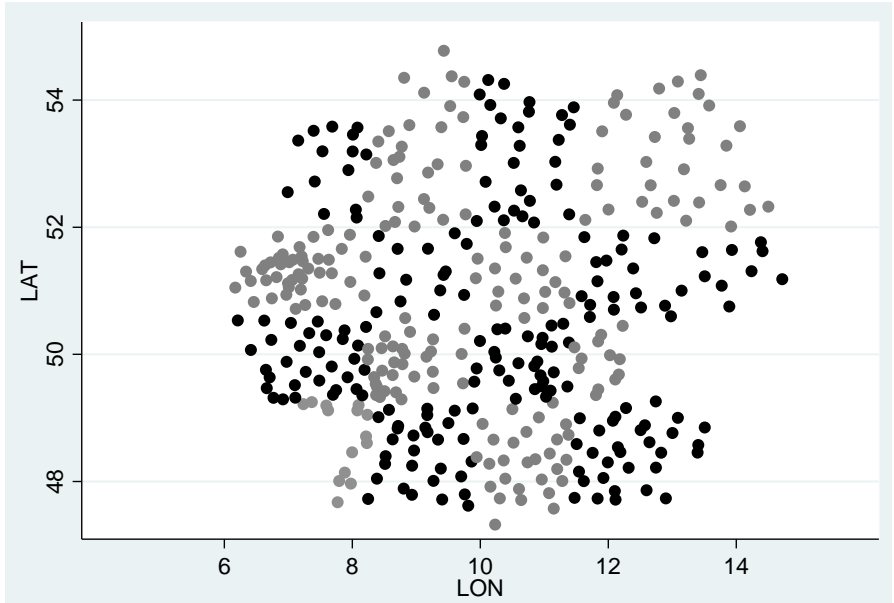


Table A.1: Historical Antisemitism and Present-Day Stock Market Participation:

\section{Robustness}

This table reports average marginal effects computed after estimating the following probit spefication:

$\operatorname{Pr}\left(\right.$ HoldsStocks $\left._{i k} \mid X_{i k}, K_{k}\right)=\Phi\left(\alpha+\beta \times\right.$ Historical Antisemitism ${ }_{k}+X_{i k}^{\prime} \times \gamma+K_{k}^{\prime} \times \delta+$ Income_deciles $\left.+\eta_{t}+\epsilon_{i k}\right)$, across subsamples defined by the column headings. Each observation is a German household interviewed by SOEP between 1984 and 2011. In all columns, the dependent variable is a dummy that equals 1 if the household holds stocks. The main covariate of interest, Historical Antisemitism, is the Voigtlaender-Voth principal component (VV P.C.) of measures of Jewish persecution in the 1920s-1930s. Individual controls include: gender, single status dummy, age (second-degree polynomial), college education dummy, homeownership dummy, and life and social insurance dummy. Historical controls include: log of Jewish population in 1933, ratio of Catholic population in 1925, log of population in 1933, ratio of population employed in the retail sector in 1933, and ratio of population employed in manufacturing in 1933. Regional controls include: income per capita, population density, share of college-educated population, latitude, and index of quality of cultivable land. $\Phi$ is the standard normal cdf. We cluster standard errors at the county level. $* p<0.10, * * p<0.05, * * * p<0.01$.

\begin{tabular}{lccc}
\hline & & & \\
& & & 0 \\
& & & 0.0 \\
& $(1)$ & $(2)$ & $(3)$ \\
\hline Historical Antisemitism & $-0.010 * *$ & $-0.011 * * *$ & $-0.013 * * *$ \\
(VV P.C.) & $(0.005)$ & $(0.004)$ & $(0.004)$ \\
\hline Observations & 13,599 & 13,599 & 11,289 \\
N. of clusters & 261 & 261 & 235 \\
(Pseudo-) R2 & 0.093 & 0.093 & 0.093 \\
Income deciles & $\mathrm{X}$ & $\mathrm{X}$ & $\mathrm{X}$ \\
Individual controls & $\mathrm{X}$ & $\mathrm{X}$ & $\mathrm{X}$ \\
Historical controls & $\mathrm{X}$ & $\mathrm{X}$ & $\mathrm{X}$ \\
Regional controls & $\mathrm{X}$ & $\mathrm{X}$ & $\mathrm{X}$ \\
Wave group f.e. & $\mathrm{X}$ & $\mathrm{X}$ & $\mathrm{X}$ \\
\hline
\end{tabular}




\section{Table A.2: Geographically Close Counties}

This Table reports average marginal effects computed after estimating the following probit specification:

$\operatorname{Pr}\left(\right.$ HoldsStocks $\left._{i k} \mid X_{i k}, K_{k}\right)=\Phi\left(\alpha+\beta \times\right.$ Historical Antisemitism ${ }_{k}+X_{i k}^{\prime} \times \gamma+K_{k}^{\prime} \times \delta+$ Income_deciles $\left.^{\prime} \eta_{t}+\epsilon_{i k}\right)$

adding the geographic fixed effects described on the column headings. Each observation is a German household interviewed by SOEP between 1984 and 2011. In all columns, the dependent variable is a dummy that equals 1 if the household holds stocks. The main covariate of interest, Historical Antisemitism, is the Voigtlaender-Voth principal component (VV P.C.) of Jewish persecution in the 1920s-1930s,. $X_{i k}$ includes the following individual-level controls: gender, single status dummy, age (second-degree polynomial), college education dummy. Other individual controls include: homeownership dummy and life and social insurance dummy. Other historical controls include: log of population in 1933, ratio of population employed in the retail sector in 1933, and ratio of population employed in manufacturing in 1933. Other regional controls include: population density, latitude, index of quality of cultivable land. Income_deciles are dummies indicating the decile of the income distribution to which the household belongs, and $\Phi$ is the standard normal cdf. We cluster standard errors at the county level. $* p<0.10, * * p<0.05, * * * p<0.01$.

\begin{tabular}{|c|c|c|c|c|c|}
\hline & 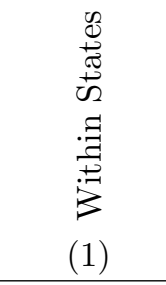 & 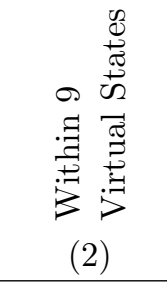 & 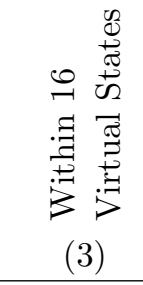 & 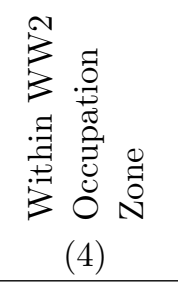 & 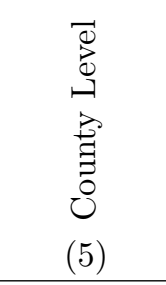 \\
\hline $\begin{array}{l}\text { Historical Antisemitism } \\
\text { (VV P.C.) }\end{array}$ & $\begin{array}{c}-0.012 * * \\
(0.006)\end{array}$ & $\begin{array}{c}-0.012 * * \\
(0.005)\end{array}$ & $\begin{array}{r}-0.010 * \\
(0.006)\end{array}$ & $\begin{array}{l}-0.018 * * * \\
(0.006)\end{array}$ & $\begin{array}{l}-0.021 * * * \\
(0.007)\end{array}$ \\
\hline Observations & 13,870 & 13,870 & 13,870 & 13,870 & \\
\hline N. of clusters & 270 & 270 & 270 & 270 & 270 \\
\hline (Pseudo-) $\mathrm{R}^{2}$ & 0.12 & 0.12 & 0.11 & 0.10 & 0.25 \\
\hline Individual contr. & $\mathrm{X}$ & $\mathrm{X}$ & $\mathrm{X}$ & $\mathrm{X}$ & \\
\hline Historical contr. & $\mathrm{X}$ & $\mathrm{X}$ & $\mathrm{X}$ & $\mathrm{X}$ & $\mathrm{X}$ \\
\hline Regional controls & $\mathrm{X}$ & $\mathrm{X}$ & $\mathrm{X}$ & $\mathrm{X}$ & $\mathrm{X}$ \\
\hline Wave group f.e & $\mathrm{X}$ & $\mathrm{X}$ & $\mathrm{X}$ & $\mathrm{X}$ & \\
\hline
\end{tabular}

Standard errors in parentheses

$* p<0.10, * * p<0.05, * * * p<0.01$ 


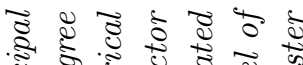
记

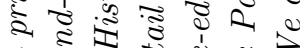

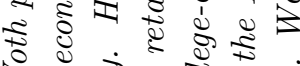

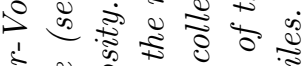
๕ (ั)

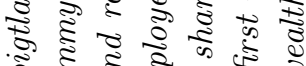

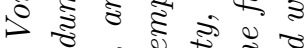

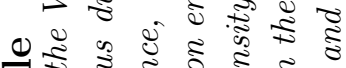

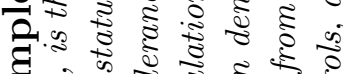
สิ हิ

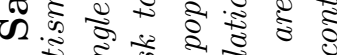

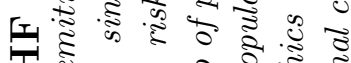
万ิ $2, \approx$ है \& उั $\ddot{0}$ ฐ

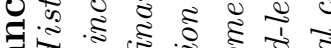
क्ष

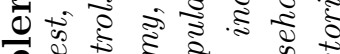

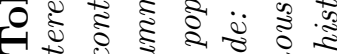
$x$. .

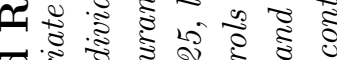
สี้

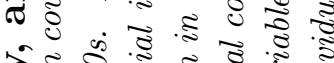

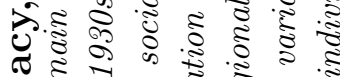

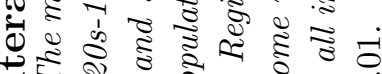

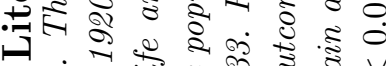

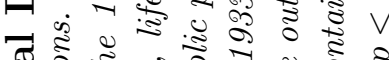

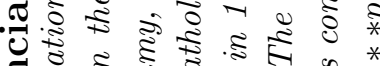
สิ

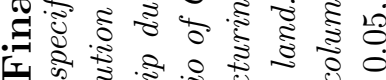

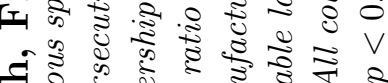

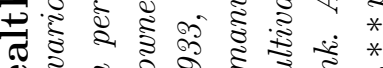
(4) ๙ कु

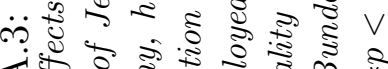
यक व

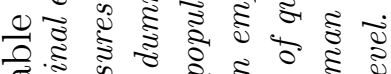

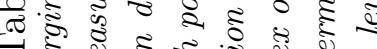

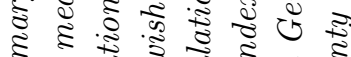
\% क -

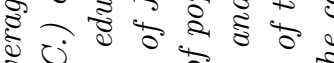
\& 8 \& 8 की

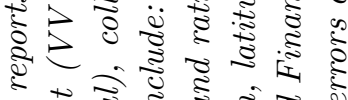

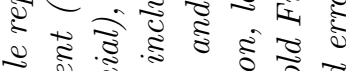

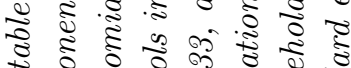

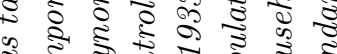

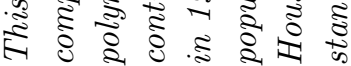

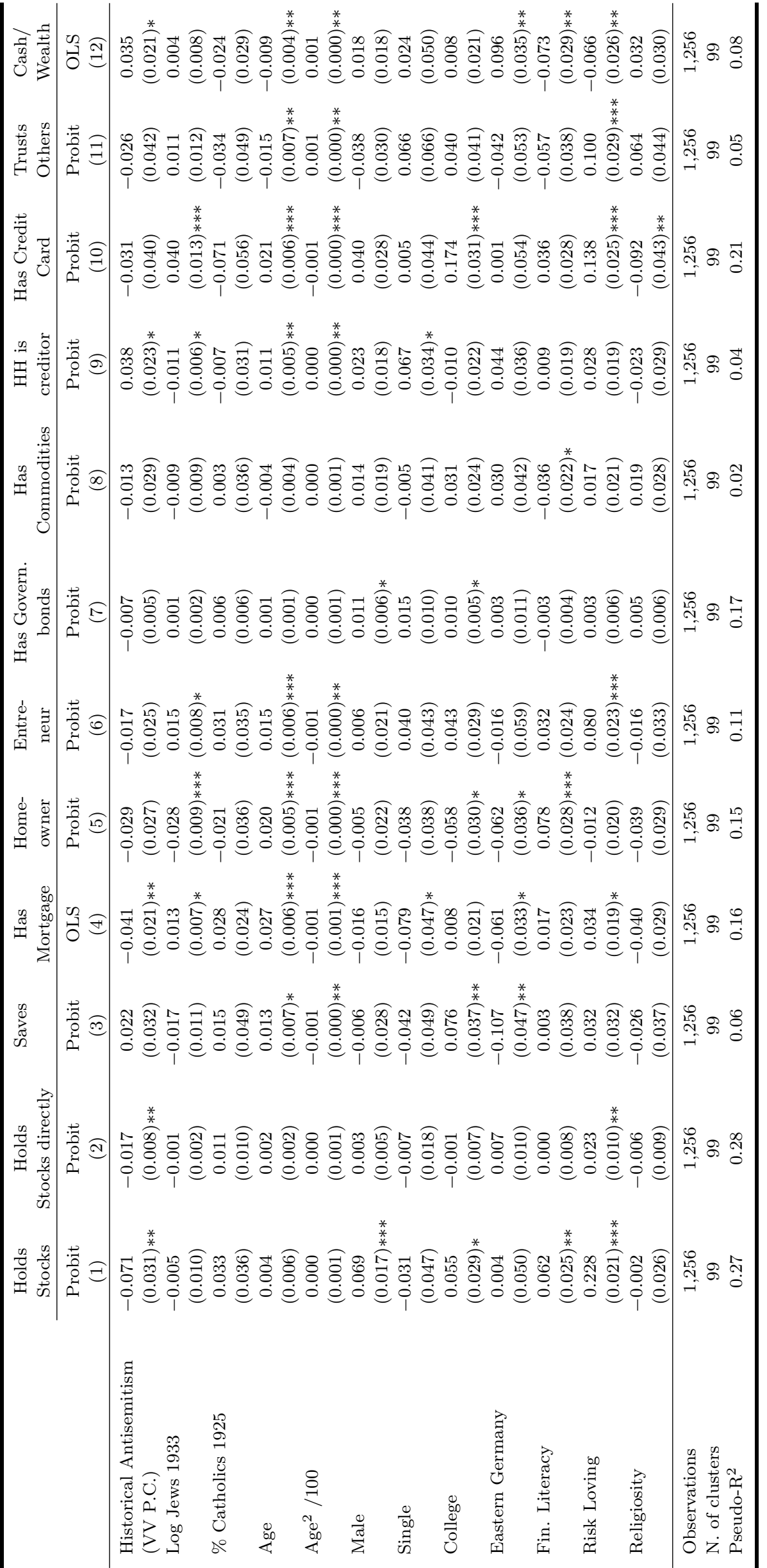




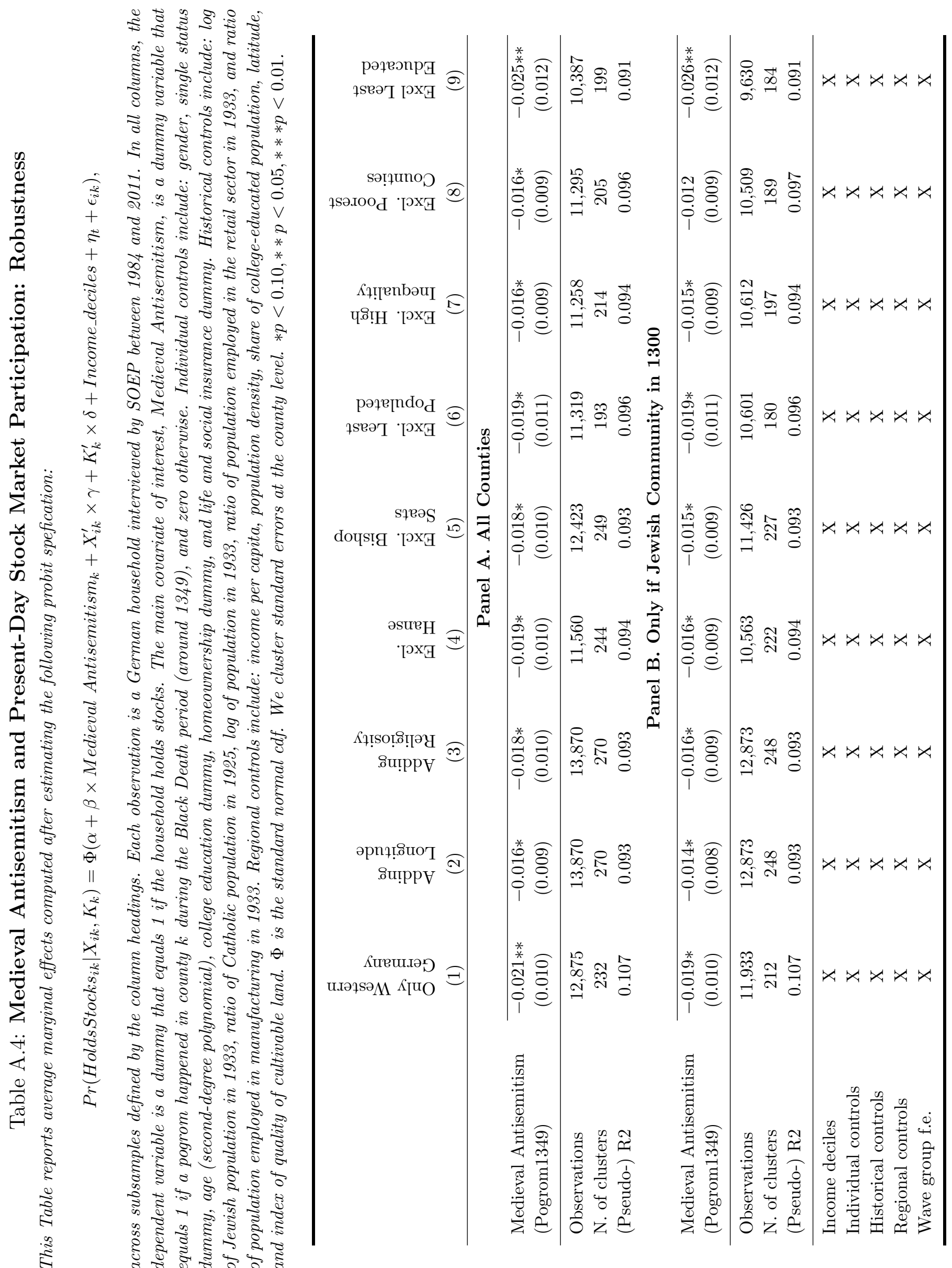




\section{Table A.5: Three-stage OLS: Distance from Rhine, Medieval Antisemitism, and Stockholdings}

This table reports OLS coefficients for the three-stage instrumental variable procedure described in section 6 . In the first stage (Panel A), the probability that a Jewish community existed in 1349 in each German county is predicted by the distance of the county from the Rhine Valley. In the second stage (Panel B), a dummy variable that equals 1 if a pogrom happened in county $k$ during the Black Death period (around 1349), and zero otherwise is predicted with the predicted probability that a Jewish community existed in a county in 1349. In the third stage (Panel C), the ratio of households who own stocks in each county is predicted with the predicted extent of Jewish persecution. In all stages observations are German counties and coefficients are estimated with OLS. Individual controls include: gender, single status dummy, age (second-degree polynomial), college education dummy, homeownership dummy, and life and social insurance dummy. Historical controls include: log of Jewish population in 1933, ratio of Catholic population in 1925, log of population in 1933, ratio of population employed in the retail sector in 1933, and ratio of population employed in manufacturing in 1933. Regional controls include: income per capita, population density, share of college-educated population, latitude, and index of quality of cultivable land. We report Hubert-White standard errors. $* p<0.10, * * p<0.05, * * * p<0.01$.

\begin{tabular}{ccccc} 
Distance & Distance & Distance & Distance & Distance \\
Mainz & Worms & Speyer & Trier & Emmerich \\
\hline
\end{tabular}

\begin{tabular}{|c|c|c|c|c|c|}
\hline \multicolumn{6}{|c|}{ Panel A. First Stage: Jewish Community Exists in 1349} \\
\hline & $(1)$ & $(2)$ & $(3)$ & $(4)$ & $(5)$ \\
\hline Log Distance & $\begin{array}{c}-0.227 * * * \\
(0.006)\end{array}$ & $\begin{array}{c}-0.199 * * * \\
(0.006)\end{array}$ & $\begin{array}{l}-0.186 * * * \\
(0.007)\end{array}$ & $\begin{array}{c}-0.131 * * * \\
(0.007)\end{array}$ & $\begin{array}{l}-0.196 * * * \\
(0.008)\end{array}$ \\
\hline Adj. $\mathrm{R}^{2}$ & 0.35 & 0.34 & 0.33 & 0.30 & 0.32 \\
\hline \multicolumn{6}{|c|}{ Panel B. Second Stage: Medieval Antisemitism (Pogrom1349) } \\
\hline Existence 1349 & $\begin{array}{l}0.784 * * * \\
(0.029)\end{array}$ & $\begin{array}{l}0.752 * * * \\
(0.034)\end{array}$ & $\begin{array}{l}0.697 * * * \\
(0.038)\end{array}$ & $\begin{array}{l}0.897 * * * \\
(0.057)\end{array}$ & $\begin{array}{l}0.842 * * * \\
(0.041)\end{array}$ \\
\hline Adj. $R^{2}$ & 0.38 & 0.37 & 0.36 & 0.36 & 0.37 \\
\hline \multicolumn{6}{|c|}{ Panel C. Third Stage: Holds Stocks } \\
\hline $\begin{array}{l}\text { Medieval Antisemitism } \\
\text { (Pogrom1349) }\end{array}$ & $\begin{array}{c}-0.016 * * \\
(0.008)\end{array}$ & $\begin{array}{c}-0.016 * * \\
(0.008)\end{array}$ & $\begin{array}{c}-0.017 * * \\
(0.008)\end{array}$ & $\begin{array}{c}-0.017 * * \\
(0.008)\end{array}$ & $\begin{array}{c}-0.017 * * \\
(0.008)\end{array}$ \\
\hline Adj. $\mathrm{R}^{2}$ & 0.08 & 0.08 & 0.08 & 0.08 & 0.08 \\
\hline Income deciles & $\mathrm{X}$ & $\mathrm{X}$ & $\mathrm{X}$ & $\mathrm{X}$ & $\mathrm{X}$ \\
\hline Individual controls & $\mathrm{X}$ & $\mathrm{X}$ & $\mathrm{X}$ & $\mathrm{X}$ & $\mathrm{X}$ \\
\hline Historical controls & $\mathrm{X}$ & $\mathrm{X}$ & $\mathrm{X}$ & $\mathrm{X}$ & $\mathrm{X}$ \\
\hline Regional controls & $\mathrm{X}$ & $\mathrm{X}$ & $\mathrm{X}$ & $\mathrm{X}$ & $\mathrm{X}$ \\
\hline Wave group f.e. & $\mathrm{X}$ & $\mathrm{X}$ & $\mathrm{X}$ & $\mathrm{X}$ & $\mathrm{X}$ \\
\hline Observations & 13,870 & 13,870 & 13,870 & 13,870 & 13,870 \\
\hline
\end{tabular}


Table A.6: Jewish Population and Geman Sectors in 1882

This table reports the number of Jewish employees by sector and the total sector size. The data are from the first Census in Prussia in 1882.

\begin{tabular}{|c|c|c|c|c|}
\hline & $\begin{array}{l}\text { Jews } \\
(1) \\
\end{array}$ & $\begin{array}{l}\text { Total sector } \\
\qquad(2)\end{array}$ & $\begin{array}{c}\text { Jews } / \\
\text { Total sector } \\
(3)\end{array}$ & $\begin{array}{c}\text { Total sector/ } \\
\text { overall workers } \\
(4)\end{array}$ \\
\hline Total working population & 357,546 & $11,037,320$ & $3.24 \%$ & $100.00 \%$ \\
\hline Unemployed & & & $2.60 \%$ & $6.12 \%$ \\
\hline \multicolumn{5}{|c|}{ Agriculture, Manufacturing, Trade } \\
\hline Agriculture & 1,641 & $4,625,893$ & $0.04 \%$ & $41.91 \%$ \\
\hline Forestry and fishing & 65 & 66,455 & $0.10 \%$ & $0.60 \%$ \\
\hline Mining and metal transf. & 1,255 & 866,794 & $0.15 \%$ & $7.85 \%$ \\
\hline Chemical & 266 & 28,908 & $0.92 \%$ & $0.26 \%$ \\
\hline Textile & 1,724 & 385,565 & $0.45 \%$ & $3.49 \%$ \\
\hline Food and beverage & 9,239 & 363,837 & $2.54 \%$ & $3.30 \%$ \\
\hline Building and construction & 1,312 & 533,925 & $0.25 \%$ & $4.84 \%$ \\
\hline Printing & 555 & 35,352 & $1.57 \%$ & $0.32 \%$ \\
\hline Retail trade & 70,175 & 466,249 & $15.05 \%$ & $4.22 \%$ \\
\hline Bookshops, art dealers & 485 & 9,580 & $5.06 \%$ & $0.09 \%$ \\
\hline \multicolumn{5}{|l|}{$\underline{\text { Services }}$} \\
\hline Engineering services & 591 & 146,650 & $0.40 \%$ & $1.33 \%$ \\
\hline Health care & 1,108 & 40,883 & $2.71 \%$ & $0.37 \%$ \\
\hline Transportation & 421 & 128,136 & $0.33 \%$ & $1.16 \%$ \\
\hline Hotels and restaurants & 3,654 & 147,061 & $2.49 \%$ & $1.33 \%$ \\
\hline Household services & 692 & 278,927 & $0.25 \%$ & $2.53 \%$ \\
\hline Military & 918 & 25,860 & $0.36 \%$ & $2.34 \%$ \\
\hline Administration & 1,093 & 119,140 & $0.92 \%$ & $1.08 \%$ \\
\hline Finance & 3,042 & 13,324 & $22.99 \%$ & $0.12 \%$ \\
\hline Insurance & 223 & 6,655 & $3.35 \%$ & $0.06 \%$ \\
\hline
\end{tabular}


Table A.7: Summary Statistics: Survey

This table reports summary statistics for the survey on trust in banks run on a representative sample of German households in 2015.

\begin{tabular}{|c|c|c|c|c|c|}
\hline & \multicolumn{5}{|c|}{ Panel A. Descriptive Statistics } \\
\hline & $\begin{array}{l}\text { Obs. } \\
(1)\end{array}$ & $\begin{array}{c}\text { Mean } \\
(2)\end{array}$ & $\begin{array}{l}\text { Std } \\
(3)\end{array}$ & $\begin{array}{c}\text { Min } \\
(4)\end{array}$ & $\begin{array}{c}\operatorname{Max} \\
(5)\end{array}$ \\
\hline Trust in the stock market & 981 & 0.13 & 0.34 & 0 & 1 \\
\hline Trust in commercial banks & 981 & 0.17 & 0.38 & 0 & 1 \\
\hline Trust in local banks & 981 & 0.41 & 0.49 & 0 & 1 \\
\hline Generalized trust & 1000 & 0.39 & 0.49 & 0 & 1 \\
\hline \multirow[t]{3}{*}{ Risk tolerance ( 1 to 7 ) } & 989 & 3.04 & 1.44 & 1 & 7 \\
\hline & \multicolumn{5}{|c|}{ Panel B. Correlations } \\
\hline & $\begin{array}{l}\text { Trust in } \\
\text { stock } \\
\text { market } \\
(1)\end{array}$ & $\begin{array}{c}\text { Trust in } \\
\text { commercial } \\
\text { banks } \\
(2)\end{array}$ & $\begin{array}{l}\text { Trust in } \\
\text { local } \\
\text { banks } \\
(3)\end{array}$ & $\begin{array}{c}\text { Generalized } \\
\text { trust } \\
(4)\end{array}$ & \\
\hline Trust commercial banks & $\begin{array}{c}0.264 \\
(0.000)\end{array}$ & & & & \\
\hline Trust local banks & $\begin{array}{c}0.132 \\
(0.002)\end{array}$ & $\begin{array}{c}0.252 \\
(0.000)\end{array}$ & & & \\
\hline Generalized trust & $\begin{array}{c}0.093 \\
(0.026)\end{array}$ & $\begin{array}{c}0.095 \\
(0.023)\end{array}$ & $\begin{array}{c}0.106 \\
(0.013)\end{array}$ & & \\
\hline Risk tolerance & $\begin{array}{c}0.383 \\
(0.000)\end{array}$ & $\begin{array}{c}0.127 \\
(0.002)\end{array}$ & $\begin{array}{c}0.022 \\
(0.594)\end{array}$ & $\begin{array}{c}0.161 \\
(0.000)\end{array}$ & \\
\hline
\end{tabular}

